\title{
DESEMPENHO DO FEIJOEIRO EM ROTAÇÃO COM MILHO E ADUBOS VERDES
}

\author{
ELAINE BAHIA WUTKE
}

Engenheiro Agrônomo

Orientador: Prof. Dr. ANTONIO LUIZ FANCELLI

Tese apresentada à Escola Superior de Agricultura "Luiz de Queiroz", Universidade de São Paulo, para obtenção do título de Doutor em Agronomia, Área de Concentração: Fitotecnia .

P I R A C I C A B A

Estado de São Paulo - Brasil

Janeiro - 1998 
Dados Internacionais de Catalogação na Publicação (CIP) DIVISÃO DE BIBLIOTECA E DOCUMENTAÇÃO - Campus "Luiz de Queiroz"/USP

Wutke, Elaine Bahia

Desempenho do feijoeiro em rotação com milho e adubos verdes / Elaine Bahia Wutke. - Piracicaba, 1998.

$146 \mathrm{p}$.

Tese (doutorado) - - Escola Superior de Agricultura Luiz de Queiroz, 1998. Bibliografia.

1. Adubação verde 2. Feijão irrigado 3. Fitotecnia 4. Milho 5. Planta cultivada 6. Rendimento 7. Rotação de cultura I. Título

CDD 635.652 


\title{
DESEMPENHO DO FEIJOEIRO EM ROTAÇÃO COM MILHO E ADUBOS VERDES
}

\author{
ELAINE BAHIA WUTKE
}

Aprovada em: 12.03 .1998

Comissão julgadora:

Prof. Dr. Antonio Luiz Fancelli ESALQ/USP

Prof. Dr. Durval Dourado-Neto ESALQUSP

Prof. Dr. Quirino Augusto de Camargo Carmello ESALQ/USP

Prof. Dr. Eduardo Antonio Bulisani IAC/S.AA

Prof. Dr. Flávio Bussmeyer Arruda IAC/SAA

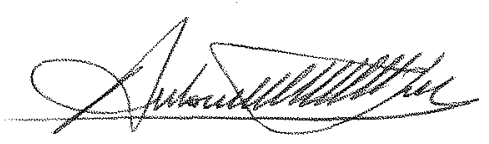

Prof. Dr. ANTONIO LUIZ FANCELLI Orientador 
Aos meus pais Margarida Maria e Antônio Carlos, às minhas irmãs Maria Cristina e Ana Cláudia

e ao meu cunhado Luiz Egydio

meu reconhecimento e gratidão pelo constante apoio.

"Em qualquer parte da Terra

um homem estará sempre plantando,

recriando a Vida, recomeçando o Mundo"

Cora Conalina

\author{
A Júlia e Otávio \\ meus grandes amores \\ dedico este trabalho
}




\section{AGRADECIMENTOS}

- Ao professor Dr. Antonio Luiz Fancelli, pelos ensinamentos transmitidos e orientação;

- Aos Drs. Manoel Albino Coelho de Miranda e Flávio Bussmeyer Arruda, do Instituto Agronômico do Estado de São Paulo/IAC, pelas sugestões e o apoio irrestrito;

- Ao IAC, pela liberação concedida para a realização deste curso;

- Ao Curso de Pós-Graduação em Fitotecnia da Escola Superior de Agricultura "Luiz de Queiroz"-ESALQ/USP, pela possibilidade de realização do Curso:

- Ao Conselho Nacional de Desenvolvimento Cientifico e Tecnologico/CNPq, pela concessão de bolsa de estudo;

- Aos colegas da Seção de Leguminosas do IAC, Dr. Roberto T. Tanaka. Dr. Hipólito A.A. Mascarenhas, Dr. Manoel A.C. de Miranda, Dr. Nelson R. Braga. Dr.Edmilson J. Ambrosano e $\mathrm{Dr}^{\mathrm{a}}$ Sandra dos S.S. Nogueira, pelo excelente ambiente de trabalho, amizade, estímulo e colaboração;

- Aos pesquisadores Guido de Sordi e José Carlos V.N.A. Pereira e ao técnico de apoio Osvaldo Gentilin Júnior, e demais funcionários da Estação Experimental de Ribeirão Preto do IAC, pela acolhida, amizade e total colaboração nos trabalhos de campo:

- À Dra.Gláucia M.B. Ambrosano, da Seção de Técnica Experimental e Cálculo do IAC, pelo auxilio valioso na orientação das análises estatisticas deste trabalho:

- Ao Dr. José A. Quaggio, da Seção de Fertilidade de Solo e Nutrição de Plantas do IAC, pela colaboração na execução das análises químicas de solo;

- À Denise R.S.Abreu, da Seção de Climatologia Agricola do LAC. pela gentileza na liberação dos dados meteorológicos;

- À Cargill-Sementes Híbridas, pela doação de sementes de milho; 
- Ao Dr. Fernando J. Hass, do LAGRO Laboratónio Agronòmico S/C Ltda., pela execução graciosa de análises químicas foliares;

- Aos funcionários dos Departamentos de Agricultura, Horticultura e Fitopatologia da ESALQ/USP, em especial Adriana A.T.Gimenes, Maria Ivete M.de Almeida. Elisabete S. São João, Maria Célia Rodrigues, Sílvia Borghesi, Helena R. Camargo, Maria Heloísa D.Moraes e Raquel F. Castelani, pela amizade e constante colaboraçào;

- Aos colegas do Curso de Pós-Graduação em Fitotecnia, em especial. Regina de M. Pires, Rose Mary Pio, Fábio Costa, Milene M. da S.R. de Souza e Laura M.M. Melletti, pelo convivio, amizade e constante incentivo;

- Aos pesquisadores do IAC, Maria Regina G.Ungaro, Afonso Peche Filho, Emilio Sakai, Sônia C.F. Dechen, Sidney R. Vieira e José Guilherme de Freitas, pela colaboração irrestrita na liberação de funcionários para auxilio nas diversas etapas deste trabalho;

- Aos pesquisadores Silvânia H.F.de Oliveira e Ana Maria Sannazzaro. do Instituto Biológico e Edmilson J. Ambrosano e Sérgio A. Carbonell do IAC pelo apoio e colaboração na execução de trabalhos institucionais sob nossa coordenação:

- Aos funcionários das Seções de Leguminosas, Irrigação e Drenagem Maquinas e Movimentação do Solo, Conservação do Solo, Oleaginosas. Artoz e Cereais de Inverno e Fertilidade de Solo e Nutrição de Plantas do IAC, em especial Nair A dos Santos, Francisco Vidal Filho, Otávio Bovo, Virginia M.B.Villar, Douglas R.dos Santos, Carmelina A.Fazani, Leonardo R.Teixeira, Amarildo C da Silva Luzia A.F.da Silva, André L.G.Castilho, José Norberto da Silva, Eleno T.da Silva e Gilberto N.da Luz, pela cooperação nos trabalhos de campo e laboratório;

- À Piraí Sementes, em especial ao Eng ${ }^{\circ}$ Agr $^{\circ}$ José A. Donizeti Carlos. pelo apoio na confecção da tese;

- A todos que, direta ou indiretamente, contribuiram para a realizaçào deste trabalho. 0 meu sincero agradecimento. 


\section{SUMÁRIO}

Página

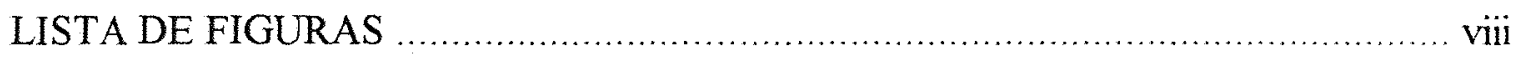

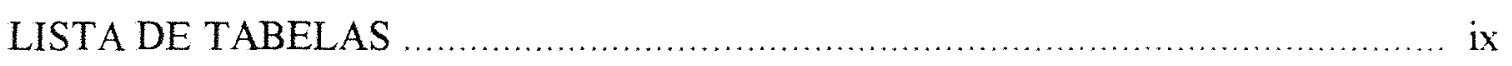

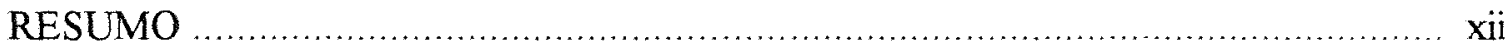

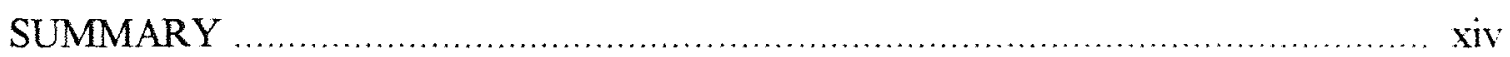

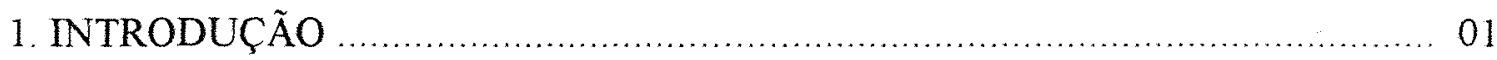

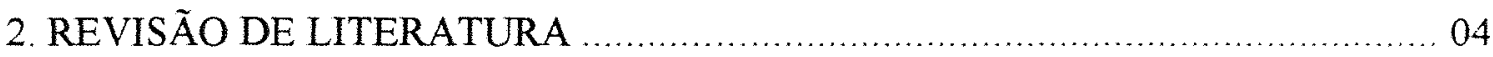

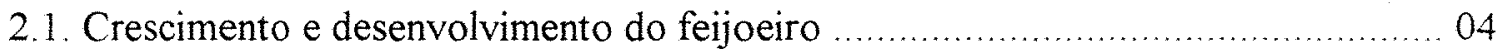

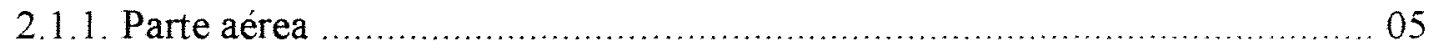

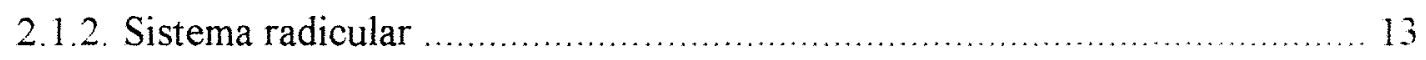

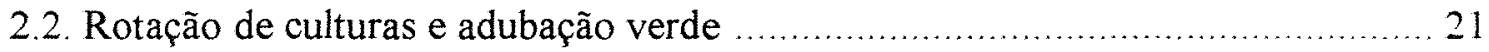

3. MATERIAL E MÉTODOS ......................................................... 29

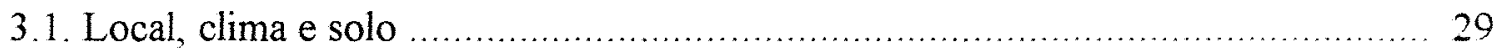

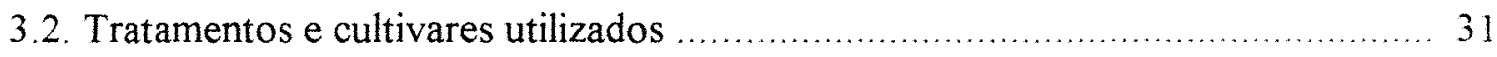

3.3. Delineamento experimental e análise estatística ................................... 31

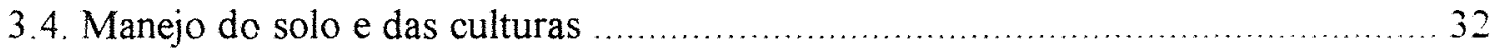

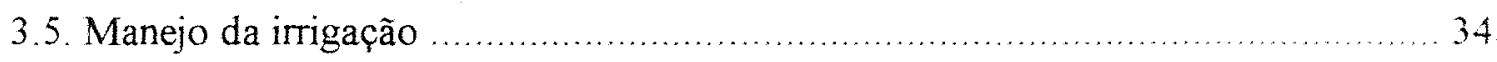

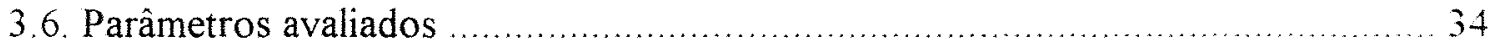

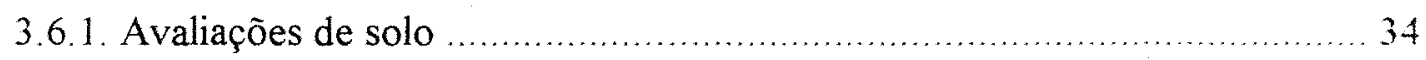

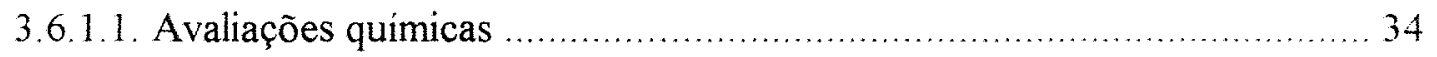

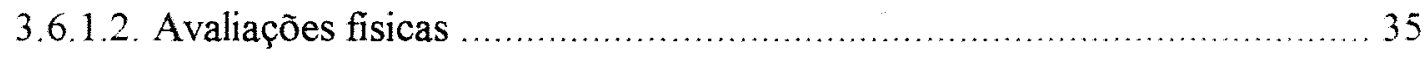

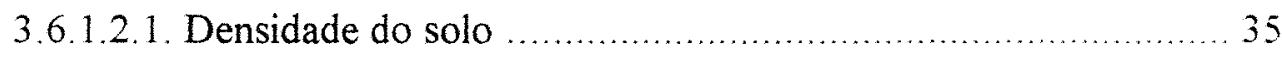

3.6.1.2.2. Avaliação do perfil de resistência à penetração ................... 35

3.6.1.2.3. Velocidade de infiltração básica (VIB) .......................... 36

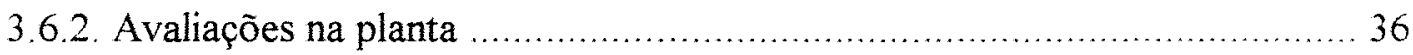

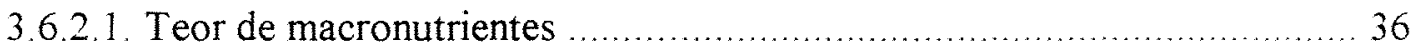

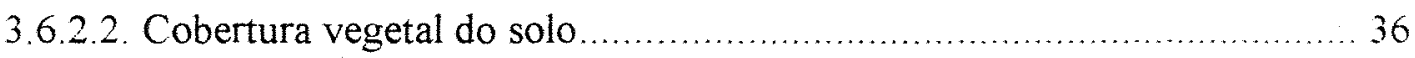




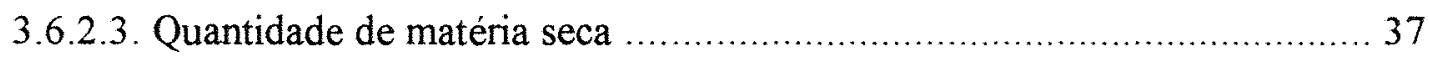

3.6.2.4. Índice de área foliar (IAF) ........................................................ 37

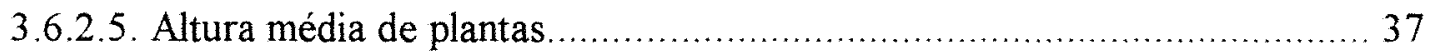

3.6.2.6. Avaliação do sistema radicular ................................................... 37

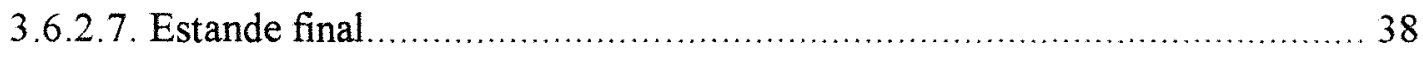

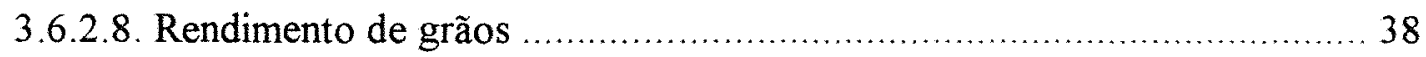

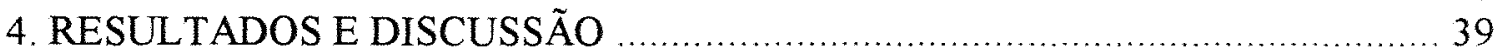

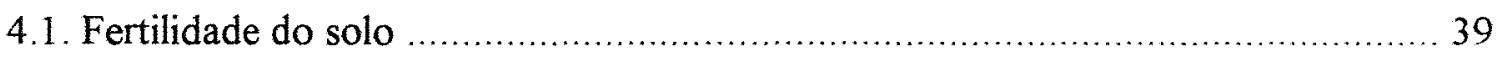

4.2. Densidade do solo e resistência à penetração (RP) ….................................... 49

4.3. Velocidade de infiltração básica (VIB) …................................................... 55

4.4. Teor de macronutrientes …................................................................. 57

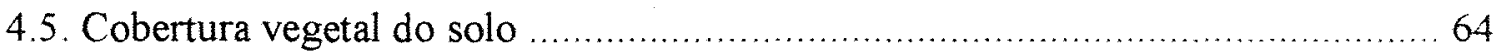

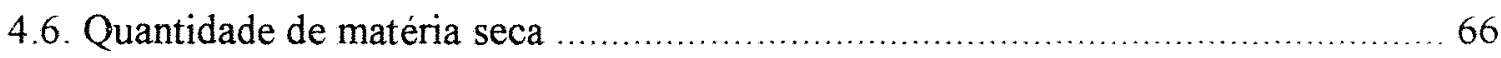

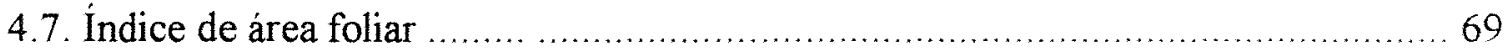

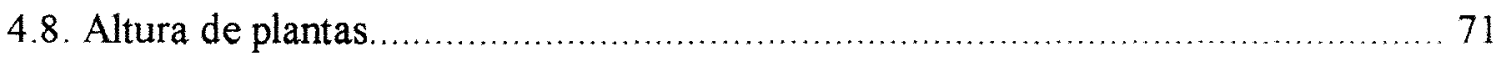

4.9. Desenvolvimento do sistema radicular ................................................. 73

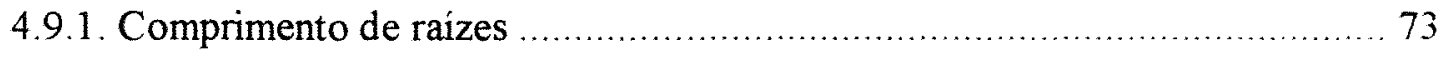

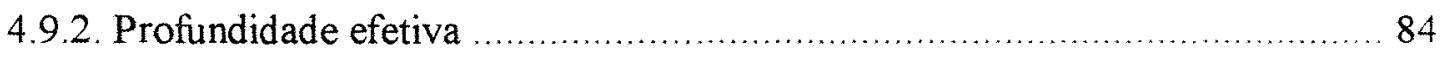

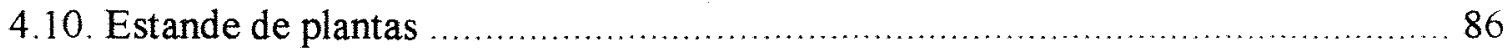

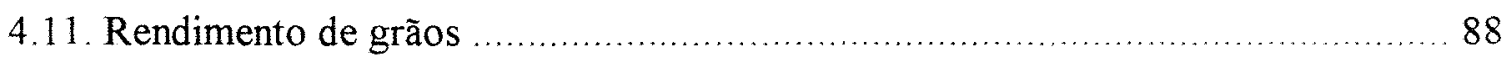

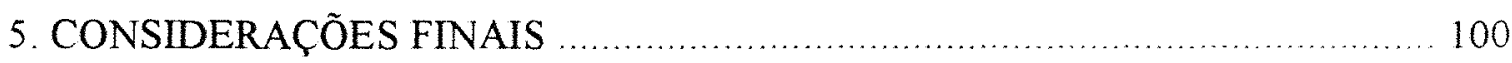

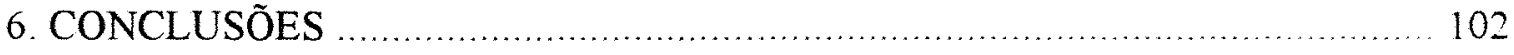

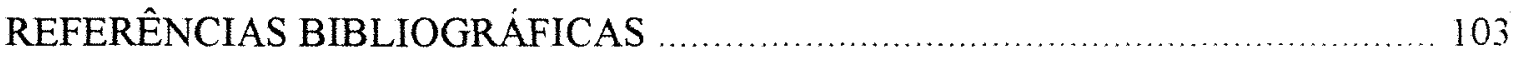




\section{LISTA DE FIGURAS}

Página

1. Valores médios de resistência à penetração $(\mathrm{RP}) \pm$ erro padrão da média (epm), em MPa, com penetrômetro de impacto, modelo IAA/PLANALSUCAR, em diferentes profundidades, em latossolo roxo cultivado com feijoeiro, após rotação com culturas graníferas e adubos verdes. Ribeirão Preto, São Paulo, 1993

2. Valores médios de resistência à penetração $(\mathrm{RP}) \pm$ erro padrão da média (epm), em MPa, com penetrômetro de impacto, modelo IAA/PLANALSUCAR, em diferentes profundidades, em latossolo roxo cultivado com feijoeiro, apos rotação com culturas graniferas e adubos verdes. Ribeirão Preto, São Paulo, 1994

3. Valores médios de resistência à penetração $(\mathrm{RP}) \pm$ erro padrão da média (epm), em MPa, com penetrômetro de impacto, modelo IAA/PLAN.ALSUCAR em diferentes profundidades, em latossolo roxo cultivado com feijoeiro. apos rotação com culturas graniferas e adubos verdes. Ribeirão Preto, São Paulo, 1995

4. Distribuição percentual média do sistema radicular do feijoeiro. no estádio $R_{7}$. em diferentes profundidades, após rotação com culturas graniferas e adubos verdes Ribeirão Preto, São Paulo, 1993

5. Distribuição percentual média do sistema radicular do feijoeiro, no estádio $R_{7}$, em diferentes profundidades, após rotação com culturas graniferas e adubos verdes. Ribeirão Preto, São Paulo, 1994

6. Distribuição percentual média do sistema radicular do feijoeiro, no estadio $R_{7}$, em diferentes profundidades, após rotação com culturas graniferas e adubos verdes. Ribeirão Preto, São Paulo, 1995 


\section{LISTA DE TABELAS}

Página

01. Temperaturas máxima, mínima e média e precipitação pluvial obtidas no posto meteorológico da Estação Experimental do Instituto Agronômico, em Ribeirão Preto, SP, em períodos decendiais de julho a novembro de 1993, agosto a novembro de 1994 e setembro de 1995 a janeiro de 1996

02. Composição granulométrica e análise textural de amostra de latossolo roxo utilizada em experimento na Estação Experimental do Instituto Agronômico, Ribeirão Preto, São Paulo. 1992

03. Datas de semeadura, florescimento e colheita do feijoeiro após a rotação com milho/culturas graniferas e adubos verdes no periodo 25/02/1992 a 07/01/1996. na Estação Experimental do Instituto Agronômico, em Ribeirão Preto, SP.....

04. Fitomassa verde de culturas antecedendo o feijoeiro em rotação. Ribeirão Preto, São Paulo. 1993, 1994 e 1995

05. Teores de nutrientes em amostra de latossolo roxo utilizado em experimento. na profundidade de $0-20 \mathrm{~cm}$, na Estação Experimental do Instituto Agronòmico. em Ribeirão Preto, São Paulo, 1992

06. Características químicas de um latossolo roxo, em três profundidades, cultivado com feijoeiro em rotação de culturas. Ribeirão Preto, SP, 1993

07. Características químicas de um latossolo roxo, em três profundidades, cultivado com feijoeiro em rotação de culturas. Ribeirão Preto, SP, 1994 
08. Características químicas de um latossolo roxo, em três profundidades, cultivado com feijoeiro em rotação de culturas. Ribeirão Preto, SP, 1995

09. Densidade de um latossolo roxo, em duas profundidades, após cultivo do feijoeiro, cultivar IAC-Carioca, em rotação com milho/culturas graniferas e adubos verdes. Ribeirão Preto, SP, janeiro de 1996

10. Infiltração básica (VIB) em um latossolo roxo, após cultivo com feijoeiro, cultivar IAC-Carioca, em rotação com milho/culturas graniferas e adubosverdes. Ribeirão Preto, São Paulo, janeiro de 1996

11. Teores de macronutrientes em folhas de feijoeiro,cultivar IAC-Carioca, no estádio $\mathrm{R}_{7}$, em rotação com milho/culturas graniferas e adubos verdes. Ribeirão Preto, São Paulo, 1994 e 1995

12. Cobertura do solo por plantas de feijoeiro, cultivar IAC-Carioca, no estádio $R_{7}$, após rotação com milho/culturas graniferas e adubos verdes. Ribeirão Preto, São Paulo, 1994 e 1995

13. Quantidade de matéria seca da parte aérea de plantas de feijoeiro. cultivar IACCarioca, no estádio $\mathrm{R}_{7}$, após rotação com milho/culturas graniferas e adubos verdes Ribeirão Preto, São Paulo, 1994 e 1995

14. Índices de área foliar (IAF) de plantas de feijoeiro, cultivar IAC-Carioca, no estádio $R_{6}$ para $R_{7}$, após rotação com milho/culturas graniferas e adubos verdes. Ribeirão Preto, São Paulo, 1994 e 1995

15. Altura de plantas de feijoeiro, cultivar IAC-Carioca, no estádio $\mathbf{R}_{8}$ apos rotação com milho/culturas graniferas e adubos verdes. Ribeirão Preto. SP. 1994 e 1995 
16. Densidade de comprimento e o respectivo erro padrão de raizes finas de feijoeiro, cultivar IAC-Carioca, no estádio $\mathrm{R}_{7}$, após rotação com milho/culturas graniferas e adubos verdes, e em diferentes profundidades. Ribeirão Preto, SP, 1993, 1994 e 1995

17. Profundidade efetiva ( $80 \%$ ) do sistema radicular do feijoeiro irrigado, em $\mathrm{cm}$. em latossolo roxo, após rotação com culturas graniferas e adubos verdes. Ribeirão Preto, SP, 1993 a 1995

18. Estande de plantas de feijoeiro, cultivar IAC-Carioca, no estádio $R_{9}$, em rotação com milho/culturas graniferas e adubos verdes. Ribeirâo Preto, São Paulo, 1993 a 1995

19. Rendimento de grãos de feijoeiro, cultivar IAC-Carioca, em rotação com milho/ culturas graniferas e adubos verdes. Ribeirão Preto, SP, 1992 a 1995 90

20. Coeficientes de correlação linear (r) entre características fisiologicas e agronômicas do feijoeiro, cultivar IAC-Carioca, em diferentes anos agricolas 99 


\title{
DESEMPENHO DO FEIJOEIRO EM ROTAÇÃO COM MILHO E ADUBOS VERDES
}

\author{
Autor: Elaine Bahia Wutke \\ Orientador: Prof. Dr. Antônio Luiz Fancelli
}

\section{RESUMO}

Um experimento foi instalado em Latossolo Roxo, na Estação Experimental do Instituto Agronômico (IAC), no municipio de Ribeirào Preto. Sào Paulo para serem avaliados os efeitos da rotação com a cultura do milho e com os adubos verdes aveia preta (Avena strigosa), crotalária júncea (Crotalaria juncea L.), guandu (Cajamus cajan (L.) Millsp.) e mucuna preta (Mucuna aterrima), no outono-inverno, seqüencialmente ao feijoeiro/milho de ciclo precoce, na produção do feijoeiro. cultivar IAC-Carioca, irrigado por aspersão sob pivô central, e as relações com paràmetros básicos do solo e da planta, no periodo de 1992 a 1996.

$\mathrm{O}$ delineamento experimental adotado foi o de blocos ao acaso com seis repetições, constituído por seis tratamentos compostos das seguintes sucessões de culturas: $\mathrm{T}_{1}=$ feijoeiro/milho/pousio; $\mathrm{T}_{2}=$ feijoeiro/milho/milho; $\mathrm{T}_{3}=$ feijoeiro/milho/aveia preta; $T_{4}=$ feijoeiro/milho/crotalária júncea; $T_{5}=$ feijoeiro/milho/guandu e $T_{6}=$ feijoeiro/milho/mucuna preta. A distribuição dos tratamentos em cada bloco foi realizada no primeiro ano e mantida em todos os anos da experimentaçào. Os dados foram analisados segundo Duncan, ao nivel de $5 \%$.

O preparo do solo foi do tipo convencional, constituido de aração e de gradagem niveladora e a semeadura do feijoeiro foi realizada cerca de uma semana após o corte e a incorporação dos adubos verdes e da aveia preta e da colheita do milho safrinha.

Para o manejo da irrigação foram utilizados tensiòmetros instalados dois a $15 \mathrm{~cm}$, dois a $30 \mathrm{~cm}$ e dois a $45 \mathrm{~cm}$ de profundidade. O momento de aplicaçào da água 
foi definido quando o potencial de água atingiu $0,05 \mathrm{MPa}$, com base na leitura dos dois tensiômetros instalados a $15 \mathrm{~cm}$. As adubações, capinas e pulverizações foram realizadas conforme recomendações da pesquisa e sempre que necessário.

Foram avaliadas, para a cultura do feijoeiro, as condições quimicas do solo; a velocidade de infiltração básica do solo (VIB); a densidade do solo; o perfil de resistência à penetração neste solo; o teor foliar de macronutrientes: a cobertura vegetal do solo; a quantidade de matéria seca; o índice de área foliar (IAF); a altura das plantas; o desenvolvimento do sistema radicular; o estande final; o rendimento de grãos e as correlações lineares entre alguns destes parâmetros.

Pela análise dos resultados obtidos, a inclusão da mucuna preta no periodo não convencional de outono-inverno, antes da seqüência feijoeiro/milho de ciclo precoce. contribuiu para o aumento no rendimento de grãos do feijoeiro em relaçào ao pousio. A avaliação do comprimento do sistema radicular mostrou-se um importante indicador dos efeitos da rotação de culturas no desenvolvimento do feijoeiro irrigado. A inclusão da mucuna preta, da crotalária juncea e do milho, no periodo não convencional de outonoinverno, antes da seqüência feijoeiro/milho, contribuiu para o aumento do comprimento do sistema radicular do feijoeiro, até a profundidade de $60 \mathrm{~cm}$. mas não alterou a sua profundidade efetiva que, para fins de manejo de irrigação, em latossolo roxo. è de 35 a $40 \mathrm{~cm}$. A rotação de culturas incluindo o feijoeiro irrigado, seguido do milho e a seguir por pousio, milho e adubos verdes reduz a resistência à penetraçào do solo: garante a manutenção de um teor normal em materia orgânica do solo e possibilita a reduçào da sua acidez e o aumento de sua saturação por bases (V\%) em profundidade

A inclusão da mucuna preta e da crotalaria juncea no periodo não convencional de outono-inverno, antes da seqüência feijoeiro/milho de ciclo curto, favorece o feijoeiro em relação aos teores foliares de potássio; à cobertura vegetal do solo e ao índice de área foliar (IAF). A velocidade de infiltração básica do solo (VIB) também foi favorecida. Não se observaram diferenças significativas entre os tratamentos para as avaliações de teores foliares de nitrogênio, fósforo e potássio: quantidade de matéria seca; altura de plantas e densidade de comprimento de raizes de feijoeiro. 


\title{
PERFORMANCE OF COMMON BEANS IN ROTATION WITH CORN AND GREEN MANURE CROPS
}

\author{
Author: Elaine Bahia Wutke \\ Adviser: Prof. Dr. Antônio Luiz Fancelli
}

\section{SUMMARY}

An experiment was carried out from 1992 to 1996 at the Instituto Agronômico Experimental Station, at Ribeirão Preto, SP, in a typic Haplorthox soil. The objective was to evaluate the effects of rotation with maize and the green manure crops: oat (Avena strigosa), sunnhemp (Crotalaria juncea L.), pigeon pea (Cajanus cajan (L.) Millsp.) and velvet bean (Mucuna aterrima), on the production of common bean (variety IAC-Carioca), under center pivot irrigation. These species were cropped in the autumn and the common bean followed them.

The experimental design was a randomized block with six replications. The six treatments which followed the adopted successions were: $T$ l = bean com/fallow; $\mathrm{T} 2=$ bean $/$ corn/corn; $\mathrm{T} 3=$ bean/corn/oat; $\mathrm{T} 4=$ bean/com sunnhemp, $\mathrm{T} 5=$ bean/corn/pigeon pea and $\mathrm{T} 6=$ bean/corn/velvet bean. The distribution of the treatments in each block was done in the first year and maintained during the all four years. The data were analised using Duncan test at the $5 \%$ level.

The soil preparation consisted of plowing and harrowing. Beans were sowed one week after cutting and incorporating the biomass of green manure crops and after harvesting corn. Two tensiometers were installed at $15 \mathrm{~cm}$. two at $30 \mathrm{~cm}$ and two at $45 \mathrm{~cm}$ of depth for the irrigation management. The time of irrigation was defined as the 
water potential reached $0,05 \mathrm{Mpa}$, according to the tensiometers installed at $15 \mathrm{~cm}$ of depth.

The common bean production was related to the main characteristics of soil and plant which consisted of the soil chemistry, the basic infiltration rate, the soil density, the mechanical soil resistance, the macronutrients contents in the leaves, the amount of dry matter, the leaf area index, soil cover, the average plant height, the root development, plant population and grain yield. Correlations between some of these characteristics were obtained in the common bean crop.

The results show that the inclusion of velvet bean during the autumnwinter period in the crop sequence contributed to increase grain vield of beans. The evaluation of the lenght of the root system is important to understand the effects of crop rotation on development of irrigated common beans plants. The inclusion of velvet bean, sunnhemp and corn, during the autumn-winter period in the crop sequence contributed to increase the lenght of root system of bean plants up to the depth of $60 \mathrm{~cm}$. However it did not alter the effective root depth $(80 \%$ of total), which was around 35 to $40 \mathrm{~cm}$. The common bean rotations with grain and green manure crops reduced the impedance of the soil penetration, maintained the normal contents of the soil organic matter, reduced the acidity and increased the base saturation index with depth. The inclusion of velvet bean and sunnhemp, during the autumn-winter period in the crop sequence contributed positively to the increase of the potassium concentration in the leaves. the soil cover and the leaf area index (LAI). The basic infiltration rate was also increased. No significant differences were observed for nitrogen, phosphorus and potassium contents in the leaves. the amount of dry matter, the average plant height and the root development of common beans. 


\section{INTRODUÇÃO}

O feijão é componente importante da dieta alimentar da população da América Latina e África e, sobretudo da brasileira, constitutindo-se na principal fonte de proteina vegetal, com teor médio de $21 \%$ nos grãos. Também. é um alimento energético, apresentando cerca de 341 calorias/100 gramas. É cultivado desde $52^{\circ}$ latitude norte até $32^{\circ}$ latitude sul e do nivel do mar até mais de 3.000 metros de altitude

No Estado de São Paulo essa cultura é de importància relevante. sendo cultivada em 485 de seus municípios, cerca de 75\% do total (Lorena. 1997). '́ conduzida de forma exclusiva e "solteira" em três principais épocas: "das àguas", com semeadura em agosto/setembro; "da seca", com semeadura em janeiro/fevereiro e "de inverno irrigada", com semeadura em abril/maio, em função da região, do clima e da disponibilidade de irrigaçâo (Pinzan et al., 1994). Ocupa uma área de. aproximadamente, 206 mil hectares, com produção em torno de 240 mil toneladas e rendimento médio nas três safras ao redor de $1.170 \mathrm{~kg} /$ ha (IEA e CATI, 1997). ${ }^{2}$

O consumo nacional "per capita", entretanto. tem apresentado grandes oscilações nos últimos anos, refletindo a queda no poder aquisitivo do consumidor, a elevação do preço do produto e a diminuição na oferta de feịào no mercado, provavelmente decorrente da redução no rendimento da cultura. Nos paises denominados "centrais", por outro lado, onde as populaçōes são estacionȧias ou com pequena taxa de crescimento, a produção de alimentos é crescente graças à pesquisa agropecuária e à adoção de técnicas produtivas. A pesquisa agricola tanto nacional quanto internacional porém, ainda tem privilegiado muito mais os cereais em relaçâo às

\footnotetext{
${ }^{1}$ Lorena, B. CATI, Comunicação pessoal, 1997.

2 IEA-Instituto de Economia Agrícola e CATI - Coordenadoria de Assistència Tecnica e Integral. Previsões e Estimativas das Safras Agrícolas do Estado de São Paulo - Ano Agricola 1996/1997. 4" levantamento, abril de 1997 (não publicado).
} 
leguminosas em grãos, resultando em prejuízos para a produção e o rendimento destas (Vieira, 1988).

Para que o feijoeiro possa expressar seu potencial produtivo é indispensável que o substrato - solo - onde se desenvolve apresente condições satisfatórias, entendendo-se como isto o conjunto de caracteristicas fisico-químicas adequadas ao perfeito enraizamento e absorção de água e de nutrientes necessarios ao seu desenvolvimento (Bulisani et al., 1987). Também, para se obter um melhor desempenho na cultura dessa leguminosa e para o estabelecimento de estratégias racionais de manejo, com um enfoque sistêmico, deve-se ter pleno conhecimento da planta, em seus diversos aspectos, e dos fatores de produção disponiveis, bem como da integração efetiva desses elementos (Fancelli, 1990).

Nesse contexto, devem ser investigadas diferentes altemativas de sistemas de produção agrícola sustentável e que sejam favoráveis à obtenção de máximo rendimento econômico, considerando-se sempre a preservação, manutenção, utilização racional, restauração e melhoria dos recursos naturais.

Apesar de não muito numerosos, os trabalhos desenvolvidos com o feijoeiro e relacionados à adição de adubos orgânicos e de fitomassa incorporada ou não ao solo, além de rotação de culturas com conservação ou incorporaçào de restos vegetais, demonstraram efeitos benéficos à produtividade dessa leguminosa, conforme literatura compilada por Bulisani et al. (1992).

A irrigação também pode proporcionar grande aumento no rendimento do feijoeiro, assegurando a produção pela garantia do suprimento de água ao longo do ciclo da cultura. Apesar do elevado custo dos equipamentos para irrigaçào, o cultivo do feijoeiro irrigado no Estado de São Paulo apresentou um crescimento acentuado nos últimos anos, o que, a princípio, possibilitou solucionar, em bases técnicas, a problemática de produção de sementes (Bulisani et al., 1987).

Mesmo no verão chuvoso de São Paulo, às vezes são necessarias irrigações suplementares esporádicas principalmente para as lavouras semeadas em setembro-outubro, quando as chuvas são ainda escassas no inicio da estação. A eficiência 
do sistema de irrigação via pivô central é da ordem de 75 a $85 \%$ e as regas são feitas a cada três a cinco dias, dependendo da cultura utilizada e da época (Arruda et al., 1994).

Entretanto, tem-se observado, com relativa frequência, sinais de desequilibrio ambiental nesse sistema de produção, com consequentes prejuizos à produção e à produtividade da cultura. Esse fato evidencia a necessidade de reavaliação das práticas agrícolas adotadas para o feijoeiro irrigado, particularmente nas regiões norte, nordeste e noroeste do Estado de São Paulo, pioneiras no uso de sistema de irrigação por pivô central. Também, parte dessas estão em Latossolo Roxo o qual, segundo Oliveira \& Menk (1984), apresenta grande homogeneidade ao longo do perfil e o seu intensivo uso agricola pode destruir a estrutura original dos horizontes superiores.

A partir de 1973 houve um grande incremento na oferta do cultivar Carioca de feijoeiro no Estado de São Paulo e regiões próximas, estimulando o consumo desse cultivar e de tipos afins (Bulisani et al., 1987). Atualmente, os cultivares Carioca, IAC-Carioca (Carioca-80 SH), IAC-Carioca Aruã, IAC-Carioca Pyatã e IAC-Carioca Akytã, todos do tipo comercial de grãos Carioca, são recomendados oficialmente para cultivo no Estado de São Paulo, sendo os dois primeiros os mais utilizados pelos agricultores, particularmente na região norte e noroeste desse Estado.

Nessas regiões, a época de semeadura recomendada para o feijoeiro de inverno é de 15 de abril a 30 de junho, com rendimento médio de $2.000 \mathrm{~kg} / \mathrm{ha}$ e para o "das águas", é de 15 de julho a 30 de setembro, com rendimento variável em funçâo de nivel de tecnologia (Pinzan et al., 1994).

O presente trabalho teve como objetivo fundamental o estudo e a identificação de efeitos da rotação com culturas graniferas e para adubação verde na produção do feijoeiro irrigado sob pivô central, tendo como metas o conhecimento de alguns parâmetros fitotécnicos daquela leguminosa, tais como o desenvolvimento vegetativo e radicular e o rendimento em grãos e as relações com alguns parâmetros físico-químico básicos do solo. 


\section{REVISÃO DE LITERATURA}

\subsection{Crescimento e desenvolvimento do feijoeiro}

O crescimento de um organismo é definido como uma alteração em seu volume e peso (Fernández et al., 1982) ou, ainda, como a variação temporal da quantidade de matéria das plantas (Pereira \& Machado,1987). É um fenômeno quantitativo, afetado pela altitude e longitude e que pode ser mensurado por meio de parâmetros tais como acúmulo de matéria seca, número de nós, indice de área foliar (IAF), etc. Por sua vez, o desenvolvimento é um processo morfo-fisiologico, referindo-se a fases de diferenciações e a alterações estruturais e fisiológicas, compostas por uma série de fenômenos e eventos sucessivos, como por exemplo, o aparecimento dos botões florais (Fernández et al., 1982).

O feijoeiro é uma leguminosa (ou fabácea) anual, herbácea, de habito de crescimento determinado ou indeterminado e duração média de ciclo variando de 80 a 110 dias. Seu desenvolvimento é acentuadamente dependente de condições climáticas favoráveis, como temperaturas entre 15 e $27^{\circ} \mathrm{C}$ e precipitação pluvial mensal de cerca de 100 a $150 \mathrm{~mm}$ (Bulisani et al, 1987; Vieira, 1978). É uma planta $C_{3}$. saturando-se fotossinteticamente a intensidades de luz relativamente baixas (Portes, 1996; White, 1988), como 40 klux para folhas isoladas (Tanaka \& Fujita, 1979). Isso significa que a assimilação do $\mathrm{CO}_{2}$ atmosférico, o qual é metabolizado em compostos orgânicos formadores da estrutura das plantas, é menos rápida do que aquela verificada em plantas $\mathrm{C}_{4}$ (Monteith, 1978), o que pode limitar consideravelmente o seu cultivo em regiōes tropicais e subtropicais, em relação aos processos de fotossintese, respiração, aproveitamento de água, competitividade, saturação lumínica e fotorrespiração (Fancelli, 1990). 
O ciclo biológico do feijoeiro é caracterizado por duas fases distintas e sucessivas: a vegetativa e a reprodutiva. Estas compreendem diferentes estádios de desenvolvimento, com diferenciações morfo-fisiológicas. Não são fisiologicamente bem separadas, particularmente naquelas plantas de hábito de crescimento indeterminado, possibilitando à espécie, pela sobreposição das mesmas, a produção simultânea de folhas, flores e vagens (Fernández et al., 1982; Fernández et al., 1986; Gepts \& Fernández, 1982). Isso deve ser considerado quando da elaboração de recomendaçōes técnicas e de manejo (Fancelli \& Dourado-Neto, 1997).

Em 1750, Lineu, citado em Thornthwaite (1952) já havia caracterizado diversas fases do desenvolvimento das plantas e apresentado o objetivo da ciência fenológica, citando: "os calendários das plantas são anualmente comparados pela observação do clima, desenvolvimento das folhas e flores, amadurecimento dos frutos, queda das folhas, de modo que se dá a diferenciação das regiōes entre si".

Segundo Fancelli \& Dourado-Neto (1997), "a reunião desses conhecimentos, de forma ordenada e concisa, possibilita a determinação das relaçòes e o grau de influência dos fatores envolvidos no processo produtivo, favorecendo sobremaneira o estabelecimento de estratégias de manejo e de tomada de decisōes".

\subsubsection{PARTE AÉREA}

A fase vegetativa do feijoeiro tem seu inicio na germinação da semente, prosseguindo até $o$ aparecimento dos primeiros botões florais. $\dot{E}$ favorecida pela ocorrência de temperaturas moderadamente elevadas (entre 21 e $29,5^{\circ} \mathrm{C}$ ), disponibilidade hídrica adequada e luminosidade abundante. Já a fase reprodutiva é delimitada pela emissão dos botôes florais e pleno enchimento de vagens e maturidade das sementes (Fernández et al., 1982). É extremamente sensível à deficiência hidrica e ao excesso de água (Fancelli \& Dourado-Neto, 1997).

Gepts \& Fernández (1982) propuseram a utilizaçào de uma escala fenológica para o feijoeiro, em que o ciclo dessa leguminosa é constituído por dez estádios de desenvolvimento, identificados por um código de letras $(V=$ fase vegetativa $e$ $\mathrm{R}=$ fase reprodutiva), combinadas com coeficientes ( 0 a 9$)$ que indicam a posiçào da 
etapa de desenvolvimento da planta na escala. A duração dessas etapas pode ser afetada por diversos fatores, tais como o genótipo, determinante do hábito de crescimento e da precocidade; o clima, incluida a luminosidade, assim como as caracteristicas de umidade, físicas e de fertilidade do solo.

À exceção do primeiro estádio de desenvolvimento $\left(V_{0}\right)$, os demais estádios são descritos quase que exclusivamente com base nas alteraçôes observadas na parte aérea das plantas.

$\mathrm{O}$ estádio $\mathrm{V}_{0}$ (germinação) caracteriza-se pelo aparecimento da radicula (geralmente pelo lado do hilo) após a absorção da água pela semente, seguido pela elongação do hipocótilo, e finalizando com o aparecimento dos cotilédones na superficie do solo. Essa fase é sensível à falta de água e, segundo Magalhães \& Carelli (1972), valores superiores a 3,5 atm podem reduzir drasticamente a germinação e a elongação das células. Ainda, temperaturas inferiores a $12^{\circ} \mathrm{C}$ reduzem significativamente a taxa e a velocidade de germinação das sementes, enquanto que valores proximos a $25^{\circ} \mathrm{C}$ favorecem muito o processo (Fancelli \& Dourado-Neto, 1997).

No estádio $V_{1}$ (emergência), os cotilédones encontram-se acima da superficie do solo, com a "alça" do hipocótilo em fase de desdobramento. Há o alongamento do epicótilo e a expansão das folhas primarias. Estas são simples, unifolioladas, opostas e estão inseridas no segundo nó da haste principal.

Em $V_{2}$ (desdobramento das folhas primárias) verifica-se a completa expansão das folhas primárias, sendo que o seu tamanho potencial esta relacionado ao tamanho das sementes.

$\mathrm{O}$ estádio $\mathrm{V}_{3}$ (emissão da primeira folha trifoliolada) inicia-se quando a primeira folha verdadeira ou trifoliolada está completamente desdobrada e na posição horizontal. Nessa fase, os cotilédones encontram-se exauridos e, em geral, há a sua abscisão. A partir desse ponto observa-se um rápido desenvolvimento vegetativo da planta, a qual passa a depender diretamente dos nutrientes disponiveis no solo. No período entre os estádios $V_{0}$ e $V_{3}$ a planta de feijoeiro é mais tolerante a estresses hidricos e baixas temperaturas, desde que em niveis moderados. Segundo Caixeta (1978), o consumo de água pelo feijoeiro quase nunca excede $3,0 \mathrm{~mm} /$ dia nessas fases. 
No estádio $V_{4}$ (emissão da terceira folha trifoliolada), a terceira folha trifoliolada está completamente expandida e o ritmo de desenvolvimento vegetativo é máximo. Inicia-se também a ramificação da planta, sendo que o número e o tamanho dos ramos são influenciados pelo genótipo, condições ambientais, sistemas de produção e densidade de semeadura. Nesse período, segundo Fancelli \& Dourado-Neto (1997), a ocorrência de deficiência hídrica pode reduzir drasticamente a altura e o indice de área foliar do feijoeiro, com consequente efeito restritivo à produtividade da cultura. $\mathrm{O}$ consumo de água pode variar entre 4,0 a $4,5 \mathrm{~mm} /$ dia (Caixeta, 1978).

A altura da planta de feijoeiro é considerada um parâmetro importante pela sua relação com a produtividade, com o controle de plantas infestantes e eficiência na colheita mecânica. Nas plantas de hábito de crescimento indeterminado (tipos II, III e IV), há emissão de folhas e de ramos vegetativos mesmo após o início do florescimento.

O crescimento em altura depende da elongação ascendente da haste principal, que é função do número de nós ou posições para partes reprodutivas, e do comprimento de internódios. O número de nós e o comprimento das plantas são muito influenciados pelas condições do ambiente, como luz, temperatura e umidade (Emerson, 1916). Portanto, seria necessário um crescimento vegetativo vigoroso para se obter uma produtividade elevada.

Observou-se correlação positiva entre a produtividade da cultura do feijoeiro e a densidade de nós, ou seja, o número de nós/metro quadrado, na haste principal e nos ramos (CIAT, 1975). Entretanto, Davis \& Evans (1977) demonstraram haver correlação fenotípica negativa entre o rendimento e o número de nós por planta.

A altura do feijoeiro também pode ser influenciada pela população de plantas utilizada. Assim é que Brandes et al. (1973) obtiveram valores máximos de altura de plantas de feijoeiro aos 40 e 50 dias após a emergência, respectivamente nas maiores e menores densidades de semeadura (um milhão e 125 mil plantas/hectare). Com o aumento da densidade de semeadura tem-se uma redução do numero de ramos por planta, como demonstrado por Costa et al. (1983), um maior IAF e, conseqüentemente. menor luminosidade disponivel para cada planta. 
Em estudos de acamamento induzido realizados no Centro Internacional de Agricultura Tropical-CIAT, na Colômbia, observaram-se perdas de ate 20\% no rendimento do feijoeiro quando a redução da altura das plantas ocorreu em épocas críticas do seu desenvolvimento, como o enchimento de vagens (White, 1988).

$\mathrm{O}$ índice de área foliar (IAF), por sua vez, é uma medida de área foliar correspondente à superficie de tecido foliar produzida sobre determinada area de solo. Como a folha é o principal local da fotossintese, a taxa de produção de matéria seca pelas comunidades vegetais é função da superficie foliar, conforme estabelecido por Shibles \& Weber (1965).

Segundo Kûet \& Marshall (1971), o IAF reflete a capacidade produtiva atual de uma comunidade vegetal, sendo que esse indice, o arranjo das folhas e a altura das hastes são usualmente os fatores mais importantes na competição por luz.

Embora a área foliar seja uma característica genética, o IAF pode ser modidicado pela densidade populacional e pela aplicação de água e de fertilizantes (Yoshida, 1972). A produção de matéria seca é função do IAF até um determinado valor. Brougham (1958) observou um aumento de produção ate um certo valor do IAF, por ele denominado de "crítico", correspondendo àquele em que há interceptação de $95 \%$ da luz solar incidente ao meio dia. Por conveniência, o IAF critico é definido como o valor alem do qual a taxa de produção de matéria seca não aumenta ou aumenta muito pouco.

Em feijoeiro, o rendimento em grâos depende do IAF no florescimento. Um maior crescimento dos ramos resultará em aumento de area foliar. em maior interceptação de luz e, portanto, em maior produtividade tanto de materia seca quanto de grãos (Jones, 1971; White, 1988). A correlação entre área foliar e o rendimento, entretanto, pode ser positiva ou negativa, em função das condições climáticas na fase de florescimento e de formação de vagens (Davis, 1945). Dessa maneira, o LAF deverá se coadunar com o sistema de produção adotado e com os recursos disponiveis (Fancelli \& Dourado-Neto, 1997).

Resende et al. (1981) e Stone et al. (1988) observaram que o IAF no florescimento foi bastante afetado pelos niveis de estresse hidrico, concordando com resultados similares obtidos por Guimarães (1992), em observaram-se reduçōes de 11,6 e 
41,5\% no IAF do cultivar Carioca, sob estresses de moderado a severo, respectivamente Bascur et al. (1985) obtiveram maior manutenção da área foliar sob deficiência hídrica para o cultivar Negro Argel de feijoeiro, que é bem resistente à seca. com consequentes maiores pesos de matéria seca e de produtividade.

Alvim \& Alvim (1969) observaram valores de IAF variando de 1,4 a 7,6 na cultura exclusiva (solteira) do feijoeiro, enquanto que Portes (1996) relatou valores experimentais de IAF variando de 0,75 a 2,20 e de 0,80 a 4,00, respectivamente, durante o ciclo de plantas de feijoeiro dos cultivares Carioca e Aporé, ambos de hábitos de crescimento indeterminado tipo III, submetidos ou não a adubaçōes nitrogenadas foliares dos 25 dias até o final do florescimento. Para os dois cultivares o maximo valor de IAF foi observado ao redor dos 55 dias do ciclo, declinando rapidamente a partir dos 85 dias.

Valores máximos de IAF observados em feijoeiro são. em geral, entre 3,0 e 4,0 (White \& Izquierdo, 1991) ou, ainda, segundo White (1981). citado em White (1988) entre 3,5 e 4,5, podendo ser em torno de 4,0 com radiaçào solar entre 16 e 18 MJ m-2.dia-1 (Laing et al., 1984). Frequentemente, mostram-se inferiores ao IAF ótimo estimado como sendo o IAF na máxima taxa de crescimento da cultura (White \& Izquierdo, 1991).

O estádio $R_{5}$ (pré-florescimento ou inicio da fase reprodutiva) se inicia pelos aparecimento dos primeiros botões florais. Nos cultivares de hábitos de crescimento determinado há o desenvolvimento de botões florais no último nó da haste. enquanto que naqueles de hábito de crescimento indeterminado os rácimos florais se encontram primeiramente nos ramos inferiores, com concomitante emissão de novos nós. ramos e folhas. No final desse estádio há o alongamento dos pedunculos florais, a corola se sobressai entre as bractéolas, as pétalas adquirem a coloração tipica do cultivar e inicia-se o processo de expansão das flores (Fernández et al., 1982).

Esta fase do desenvolvimento do feijoeiro é considerada uma das mais críticas à deficiência de água, por diversos autores citados em Fancelli \& Dourado-Neto (1997). Em decorrência de um possível estresse hídrico pode haver a suspensão brusca da emissão de novas folhas nas plantas de hábito de crescimento indeterminado. com perdas de produtividade ente 15 até $30 \%$ (Fancelli \& Dourado-Neto, 1997). O consumo de água 
nessa fase varia entre 4,0 e $4,5 \mathrm{~mm} /$ dia, podendo exceder $5 \mathrm{~mm}$ quando as condições ambientais forem de intenso calor e baixa umidade relativa do ar (Caixeta, 1978).

O recobrimento total da área de cultivo no inicio do florescimento das plantas é uma medida prática do acerto da população de plantas na cultura do feijoeiro Esse fato é indicador da interceptação da energia radiante em época e quantidade adequadas aos processos fisiológicos posteriores, além do estabelecimento de competição com plantas infestantes emergentes, pela ação da cobertura do solo (Bulisani et al., 1987).

A relação entre a área de solo coberta pela vegetação e a área total disponivel para o seu crescimento é denominada cobertura vegetal ou percentagem de cobertura vegetal. Sua determinação nem sempre é muito fácil na experimentação agrícola, porém é particularmente útil aos estudos de evapotranspiração, erosão do solo e produtividade das culturas (Arruda, 1984).

Dentre os métodos descritos na literatura para a determinação da cobertura vegetal durante o ciclo das culturas, Arruda (1984) observou serem os do sensor de radiação e o da largura do dossel vegetativo como os mais adequados para a cultura do feijoeiro. Sloneker e Moldenhauer (1977) fazem referências também ao método da corda para essa leguminosa.

$O$ estádio $R_{6}$ (florescimento) se inicia pelo aparecimento das primeiras flores, correspondentes aos primeiros botões florais. Nas plantas de hábito de crescimento determinado o florescimento principia no último nó da haste principal, sendo descendente em direção aos nós inferiores, enquanto que nas de hábito de crescimento indeterminado o sentido do florescimento é ascendente (Fernández et al., 1982). Nestas últimas, as primeiras flores, que estão situadas na parte mais baixa da planta, são as mais importantes para o rendimento. Isso se deve à ordem de prioridade de formação de vagens e ao fato das últimas flores e vagens estarem sujeitas a uma elevada taxa de abscisão, abortamento ou chochamento (CIAT, 1975; Smith e Pryor, 1962). A queda natural de flores pode variar de 40 a $75 \%$, em função das condições climáticas vigentes no período (Fancelli \& Dourado Neto, 1997). 
Nesse estádio as plantas de hábito de crescimento indeterminado deverão estar com aproximadamente 20 a 22 trifoliolos completamente expandidos e fotossinteticamente ativos, de maneira que os eventos fisiológicos relacionados ao mesmo não sejam comprometidos (Fancelli, 1990). A ocorrência de baixas temperaturas poderá reduzir o crescimento do tubo polínico (quando inferiores a $10^{\circ} \mathrm{C}$ ), com consequeencias negativas no processo de fertilização, conforme mencionado em Fancelli \& DouradoNeto (1997), além de causar redução no número de vagens por planta e no número de sementes por vagem.

O consumo de água pelo feijoeiro nessa fase pode variar entre 4,0 e 4,5 $\mathrm{mm} / \mathrm{dia}$, sendo que a ocorrência de periodos de falta de água por cerca de uma semana poderá acarretar redução de $48 \%$ no rendimento (Garrido et al., 1979). Por outro lado, o excesso de água pode colaborar igualmente para a redução do rendimento em 48 a $68 \%$, se a situação de encharcamento do solo se prolongar por dois a seis dias (Silva, 1982)

$\mathrm{Em} \mathrm{R}_{7}$ (formação das vagens), a planta apresenta a primeira vagem com a corola da flor murcha e desprendida, observando-se, ainda, a emissào de novas flores. Há o desenvolvimento das vagens e nos primeiros 10 a 15 dias apos o florescimento observase principalmente o seu crescimento longitudinal e um pequeno crescimento das sementes. Esse estádio finaliza quando as vagens atingem seu tamanho final e peso máximo, iniciando-se o seu enchimento (Fernández et al. 1982).

Esta fase é extremamente sensivel à deficiència hidrica. porque pode provocar a diminuição da produtividade pela redução da fotossintese e do metabolismo das plantas (Fancelli \& Dourado-Neto, 1997). Essa diminuição na produtividade foi de $58 \%$ no periodo efetivo de formação de vagens, conforme observado por Garrido et al.(1979). Podem contribuir também para o aumento da queda de vagens imaturas (abortamento), além de causar a retração no tamanho das vagens em crescimento (Fancelli \& Dourado-Neto, 1997). O consumo de água pelo feijoeiro durante essa fase pode ser de 4,0 a $4,5 \mathrm{~mm} / \mathrm{dia}$, chegando a exceder $5 \mathrm{~mm}$ em condiçòes de intenso calor e baixa umidade relativa (Caixeta, 1978)

A ocorrência de temperatura noturna elevada (superior a $24^{\circ} \mathrm{C}$ ) pode favorecer o florescimento, devido ao incremento na atividade metabolica da planta. 
Porém, é prejudicial para a formação e retenção de vagens (Fischer \& Weaver, 1974), enquanto que a máxima taxa de abortamento de vagens imaturas ocorre quando as temperaturas diurnas são superiores a $35^{\circ} \mathrm{C}$ (Stobbe et al, 1966).

Nesse estádio, a planta pode emitir flores, vagens e até mesmo folhas, evidenciando um eficiente mecanismo de translocação de carboidratos. Assim, no manejo da lavoura feijoeira dever-se-á preservar o equilíbrio entre as fases de desenvolvimento da planta, tendo em vista o não favorecimento da produção exacerbada de folhas em detrimento das estruturas reprodutivas e a minimização das relações de competição, tanto entre folhas novas e vagens imaturas quanto entre parte aérea e sistema radicular (Fancelli \& Dourado-Neto, 1997).

$O$ estádio $R_{8}$ (enchimento das vagens) se inicia pelo enchimento da primeira vagem, que já se encontrava em seu tamanho definitivo, seguido pelo crescimento ativo das sementes e finalizado pela alteração na coloração da semente e, em sequência, da vagem. Ao final dessa fase observa-se um amarelecimento e início de abscisão das folhas inferiores e, ainda, emissão de novas folhas pelas plantas de hábito de crescimento indeterminado (Fernández et al., 1982).

A ocorrência de estresse hídrico e também nutricional pode reduzir bastante o número e o peso das sementes e portanto, a produtividade (Fancelli \& Dourado-Neto, 1997). O consumo de água nessa fase pode ser de 4,0 a $4,5 \mathrm{~mm} /$ dia. A redução no número de sementes/vagem também pode ser provocada por temperaturas elevadas (superior a $30^{\circ} \mathrm{C}$ ), que podem ainda promover um aumento na taxa respiratória (Dickson \& Boettger, 1984) e na concentração de etileno na planta, composto esse relacionado ao processo de abscisão ou queda de folhas, flores e vagens (Abeles \& Gahagan, 1968). Entretanto, se houver redução de peso na planta com a perda de algumas de suas partes, sempre hverá uma translocação da maior quantidade possivel de nutrientes e carboidratos dessas partes para a planta remanescente (White, 1988).

$O$ estádio $R_{9}$ (maturidade das vagens) é a última fase de desenvolvimento do feijoeiro, caracterizando-se pela alteração na coloração das vagens (para amarelada ou pigmentada, conforme o cultivar) e em seu teor de água. Este também se reduz até $15 \%$ nas sementes, que então adquirem sua coloração final e seu brilho típicos. O processo de 
senescência da planta se acentua, com o amarelecimento e queda abundantes das folhas. O ciclo biológico da planta se encerra e a cultura pode então ser colhida (Fernández et al., 1982). Nessa etapa do desenvolvimento a necessidade em água pela cultura é mínima a quase nula.

\subsubsection{Sistema radicular}

A distribuição de raizes no solo resulta de uma série de processos complexos e dinâmicos, incluindo-se aqui as interações entre o ambiente, o solo e as plantas em pleno crescimento. Como as raizes são imprescindiveis no processo de absorção de água e de nutrientes, os estudos sobre seu desenvolvimento, sua concentração, distribuição e atividade (taxa de crescimento e longevidade) no perfil do solo são fundamentais ao entendimento da produção das culturas (Brown \& Scott, 1984; Glinski \& Lipiec, 1990; Pearson, 1974; Taylor \& Arkin, 1981), bem como das alterações provocadas no solo e na planta por condições naturais e pelo manejo fisico-quimico do solo (Pearson, 1974).

Weaver et al., já em 1922, escreveram: "um conhecimento exato do desenvolvimento do sistema radicular das plantas cultivadas, de sua posição, extensão e atividade como elemento absorvedor de água e solutos em várias etapas do crescimento é de importância superior para o conhecimento cientifico da produção vegetal..."

A conformação do sistema radicular de uma planta depende, primeiramente, de sua constituição genética e pode se desenvolver plenamente em condições favoráveis. Porém, em condições adversas poderá haver sensiveis alterações na maneira de sua distribuição.

O feijoeiro possui um sistema radicular pivotante ramificado e sua amplitude varia de acordo com as condições fisicas do solo, tais como estrutura, porosidade, aeração, capacidade de retenção de umidade e temperatura. Em condições muito favoráveis, as raizes podem atingir mais de um metro de comprimento (Ospina, 1981; Vilhordo et al., 1996). Seu sistema radicular lateral é extenso e concentra-se principalmente nos primeiros 0,30 metros no perfil do solo. Podem ser atingidas as 
profundidades de cerca de 0,07 metros na emergência; 0,30 a 0,90 metros por ocasiâo do início do florescimento e 1,00 a 1,50 metros na maturidade das plantas, sendo que a absorção de água ocorre sobretudo até 0,50 a 0,70 metros de profundidade (Doorenbos \& Kassam, 1994).

Os trabalhos pioneiros sobre a distribuição do sistema radicular dessa leguminosa foram realizados em São Paulo, no Instituto Agronômico de Campinas (IAC), por Inforzato \& Miyasaka (1963) e Inforzato et al.(1964) e, posteriormente por Reichardt et al. (1974). As determinações desses autores, entretanto, não foram suficientemente informativas sobre as condições de solo e de cultivo.

Com o advento do uso de equipamento de irrigação por pivô central viabilizou-se um novo sistema de produção de grãos, cujas condições são diferentes daquelas tradicionais de cultivo de sequeiro. Com tal irrigação há uma exploração intensiva do solo, com pelo menos duas culturas por ano, com turno de rega de 2 a 5 dias e aplicações de lâminas reduzidas de água. As informações sobre sistema radicular até então existentes e utilizadas para orientação das irrigações foram compiladas por Arruda (1987), principalmente em condições de sequeiro ou com irrigações esporádicas.

A profundidade efetiva das raízes constitui um dos parâmetros necessários à realização de projetos e ao manejo da irrigação. O seu conhecimento possibilita a determinação da profundidade para instalação de sensores de umidade no solo para o controle das irrigações e armazenamento de água no solo (Koffler, 1986; Pires et al., 1991). Ela vem a ser a camada desde a superficie do solo em que se concentra a maioria das raizes absorventes ou finas (Daker, 1984), ou ainda, é uma fração da profundidade real máxima do sistema radicular observável em condiçôes de campo, quando a cultura se encontra no quarto estádio de desenvolvimento (Driessen, 1986).

De acordo com Dourado-Neto \& van Lier (1991), a profundidade efetiva do sistema radicular pode aumentar linearmente, conforme também sugerido por Driessen (1986), potencial ou sigmoidalmente a partir de um valor inicial até atingir um valor máximo, ao final do terceiro estádio de desenvolvimento, permanecendo constante e igual ao valor máximo até ser atingido o ponto de maturidade fisiológica ao final do quarto estádio. No quinto estádio, a profundidade efetiva do sistema radicular também pode 
decrescer linear, potencial ou sigmoidalmente, o que não fora anteriormente previsto por Driessen (1986). A profundidade máxima efetiva do sistema radicular do feijoeiro, segundo Driessen (1986), ocorre no momento em que a planta apresenta o máximo valor de IAF, entre 0,90 e 1,50 metros, corroborando com observações de Halterlein (1983).

No Brasil, em condições de sequeiro e por ocasião do florescimento das plantas, Inforzato \& Miyasaka (1963) determinaram que cerca de $84 \%$ e $97 \%$ das raizes do feijoeiro se distribuiam até $20 \mathrm{~cm}$ de profundidade, respectivamente em solo podzólico vermelho-amarelo de Monte Alegre do Sul e em solo podzolizado de Lins e Marilia, em Pindorama, São Paulo. A profundidade máxima atingida pelas raizes nos dois tipos de solo foi 0,90 metros. Resultados similares foram posteriormente obtidos por AvilanRovira (1975) e Caixeta et al. (1983), enquanto que Reichardt et al. (1974) e, mais recentemente, Pires et al. (1991) verificaram que $90 \%$ e $80 \%$ das raizes de feijoeiro situavam-se, respectivamente, nos primeiros $30 \mathrm{~cm}$ do perfil de um latossolo roxo e de um podzólico vermelho-amarelo latossólico eutrófico, este em Votuporanga, na regiào noroeste do Estado de São Paulo e em três ocasiões após o florescimento das plantas (aos 45, 62 e 78 dias após a semeadura).

Nos estudos de Avilan-Rovira (1975) a máxima profundidade atingida pelo sistema radicular do feijoeiro, cultivar Carioca, foi de $50 \mathrm{~cm}$, sendo $25 \mathrm{~cm}$ a expansão lateral máxima de concentração de raizes nas camadas superiores do perfil do solo. Ainda, a distribuição das raizes foi influenciada pelas condições fisicas do solo. Garrido et al. (1978), por sua vez, observaram $90 \%$ das raizes do feijoeiro nos primeiros $60 \mathrm{~cm}$ de profundidade

O desenvolvimento das raízes e sua atuação como superficie absorvente depende de muitos fatores relativos ao solo que as circunda. A resistência mecânica, a umidade, a aeração e a fertilidade do solo podem impor fortes restriçôes ao crescimento das raizes em regiões tropicais (Kramer, 1969; Jung, 1978).

Em função dos processos pedogenéticos ou de problemas decorrentes do manejo inadequado de um solo, podem aparecer camadas com diferentes graus de compacidade no seu perfil, as quais podem até mesmo limitar a penetração e o desenvolvimento das raizes ou restringir o fluxo de água e ar (Sakai, 1996). Em trabalho 
sobre compactação de solo em condições não naturais, Bacchi (1976) concluiu que camadas no perfil do solo apresentam mais distúrbios ao crescimento das raizes do que perfis homogêneos com maior densidade. A camada compactada induziu a uma concentração de raizes na superficie do solo. Não houve, porém, efeito de restrição ao rendimento em grãos, uma vez que as condições de umidade e de fertilidade daquele solo eram satisfatórias. Isso demontra que nem sempre se verifica uma relação direta entre produção e crescimento de raízes.

Taylor et al. (1966) observaram que a penetraçào radicular está linearmente relacionada à resistência à penetração no solo, avaliada por penetròmetro, até $2 \mathrm{MPa}$. Em seus trabalhos, Yapa et al. (1988) obtiveram valores médios de RP entre 0,75 $\pm 0,40 \mathrm{MPa}$ e 3,30 $\pm 1,72 \mathrm{MPa}$, para todas as combinações de solos e culturas (soja, Vigna mungo, V. radiata) em que, respectivamente, observaram-se $80 \%$ e $20 \%$ de penetração radicular.

Em estudos a campo, com três cultivares de feijoeiro ("Fleetwood", "Kentwood" e "Seafarer"), em solo argiloso, observou-se redução significativa da quantidade de matéria fresca tanto da parte aérea quanto das raizes, com o aumento induzido da densidade do solo de $1,22 \mathrm{~g} / \mathrm{cm}^{3}$ até $1,44 \mathrm{~g} / \mathrm{cm}^{3}$, até $14 \mathrm{~cm}$ de profundidade. Para um mesmo nível de compactação, foram relatadas maiores quantidades de materia fresca em solo argiloso do que em arenoso, possivelmente devido à sua maior disponibilidade de nutrientes e matéria orgânica e melhor capacidade de retenção de agua (Tu \& Tan, 1991).

Em plantas de feijoeiro com 14 a 28 dias de idade. sob condiçōes de avaliação em minirizotron, tanto com tubos flexíveis quanto rigidos, houve uma redução acentuada e significativa da densidade radicular com o aumento da densidade do solo de $1,5 \mathrm{~g} / \mathrm{cm}^{3}$ para $1,7 \mathrm{~g} / \mathrm{cm}^{3}$ (Volkmar, 1993).

Phillips \& Kirkhan (1962) observaram redução linear na velocidade de crescimento de raizes de milho quando a densidade do solo variou de $0,94 \mathrm{~g} / \mathrm{cm}^{3}$ para $1,30 \mathrm{~g} / \mathrm{cm}^{3}$, sendo que o comprimento das raizes foi reduzido de $52 \mathrm{~cm}$ para $10 \mathrm{~cm}$. Para essa mesma cultura, Shienlaw \& Alston (1984) verificaram uma paralisação da penetração radicular quando a densidade do solo atingiu o valor de $1.55 \mathrm{~g} / \mathrm{cm}^{3}$. 
Na cultura do arroz, Grohmann \& Queiroz Neto (1966) verificaram um impedimento físico ao desenvolvimento das raizes quando a densidade do solo foi superior a $1,42 \mathrm{~g} / \mathrm{cm}^{3}$, enquanto que Taylor \& Ratliff (1969) observaram redução da taxa de elongação do sistema radicular de amendoim de $1,9 \mathrm{~mm} / \mathrm{h}$ para $0,8 \mathrm{~mm} / \mathrm{h}$ quando os valores de RP, avaliada por penetrômetro, aumentaram, respectivamente, de $1 \mathrm{MPa}$ para $3 \mathrm{MPa}$.

Cintra \& Mielniczuck (1983) relataram redução de $50 \%$ no comprimento de raízes da soja sob densidade de solo superior a $1,3 \mathrm{~g} / \mathrm{cm}^{3}$, embora não houvesse outros efeitos negativos à cultura em situação de compactação até a densidade de de $1,4 \mathrm{~g} / \mathrm{cm}^{3}$, devido a um melhor arranjo das partículas, melhor retenção de água e de nutrientes. Moraes et al. (1991) obtiveram uma redução de cerca de $60 \%$ da massa de raizes de soja, cultivar IAS-5, em colunas de PVC com anéis cilindricos, preenchidas com latossolo roxo com densidade de $1,23 \mathrm{~g} / \mathrm{cm}^{3}$. Baligar et al. (1975), por sua vez, verificaram inclusive uma alteração da anatomia das raizes de plantas de soja submetidas a densidade de solo de $1,95 \mathrm{~g} / \mathrm{cm}^{3}$.

Em alguns trabalhos tem sido evidenciada a relação entre diminuição da penetração de raizes com a resistência que o solo compactado oferece ao ser deslocado por estas, e não às diferenças em sua densidade, teor de água ou de ar (Black, 1975; Tackett \& Pearson, 1964). Em certos casos, a aeração pode atingir niveis tão reduzidos e a resistência ser tão elevada que qualquer desses fatores, separadamente, pode ser impeditivo à penetração (Tackett \& Pearson, 1964).

$\mathrm{O}$ aumento da infiltração de água nos solos, seja por meios mecânicos ou biológicos, é uma das mais importantes medidas no controle da erosão hídrica, sendo que essa infiltração pode ser afetada pela vegetação, pela umidade antecedente ou pela estrutura dos solos (Lal, 1979). A taxa de infiltração da água é a caracteristica que, isoladamente, melhor reflete a boa qualidade estrutural de um solo. Por sua vez, esta relaciona-se a uma qualidade do espaço poroso (tamanho e distribuição dos poros), que geralmente é função do estado de agregação dos solos e de sua textura, determinando maior infiltração e redução do escoamento superficial com conseqüentemente, melhor controle da erosão (Monegat, 1991). 
As determinações obtidas com infiltrômetro reproduzem bem a proporção dos poros existentes no solo, havendo correlações significativas entre proporção de macroporos e infiltração. O processo de selamento superficial, que pode ser decisivo para a formação da erosão, não ocorre nos anéis do infiltrômetro (Sidiras \& Vieira, 1984).

$\mathrm{Na}$ situação de preparo convencional do solo verifica-se uma ação fisica do impacto das gotas de água (da chuva ou da irirgação) sobre um solo desestruturado pelo preparo. Com isso pode ocorrer uma maior desagregação de suas partículas e na ocupação dos espaços porosos pelas mesmas. Assim, apesar da maior porosidade aparente verificada no preparo convencional, pode haver uma maior dificuldade à infiltração da água, com conseqüente escoamento superficial de quantidade apreciável de água não absorvida no solo. A presença de resíduos, nesse caso e, sobretudo, como cobertura vegetal, pode minimizar esse problema, colaborando, ainda, para a manutenção da capilaridade do solo (Castro, 1995; Ehlers, 1975; Sidiras et al., 1984).

A qualidade e também a quantidade de resíduos componentes da cobertura morta estão diretamente relacionadas com a intensidade de infiltração da água em um solo. Para aquelas culturas com elevada produção de fitomassa seca, formada por material mais fino, espera-se obter uma cobertura morta densa e espessa, que confira uma boa proteção ao solo e que favoreça a infiltração (Castro, 1995). Embora as gramineas e as leguminosas possam produzir quantidades semelhantes de fitomassa, a decomposição dessas últimas é muito mais rápida, devido à sua menor relação $\mathrm{C} / \mathrm{N}$, não havendo, por muitas vezes, uma boa cobertura do solo (Castro \& De Maria, 1993).

$\mathrm{O}$ conteúdo de água no solo é um dos fatores que mais afeta o crescimento radicular (Barber et al., 1988). A água não afeta diretamente as raizes, como mostra o seu crescimento vigoroso em soluções nutritivas, adequadamente aeradas. Um excesso de água no solo desloca o ar do espaço poroso não capilar, induzindo a uma deficiência de oxigênio e, em decorrência, à morte de muitas raizes (Kramer, 1969).

$O$ feijoeiro é sensivel tanto à deficiência hidrica quanto ao excesso de água no solo, principalmente nas fases de florescimento e de desenvolvimento das vagens. $O$ consumo de água pela cultura varia basicamente com o estádio de desenvolvimento, cultivar e condições climáticas locais. Em geral, o consumo total de água pode variar de 
300 a $500 \mathrm{~mm}$ por ciclo, quando cultivado no sistema de preparo de solo convencional e de 250 a $400 \mathrm{~mm}$, em plantio direto (Moreira \& Stone, 1995).

Essa leguminosa necessita de baixa tensão de água no solo para que o seu potencial produtivo seja manifestado (Peloso et al., 1996). Garrido et al. (1978) não observaram diferenças significativas no rendimento dessa leguminosa quando a umidade nos primeiros $30 \mathrm{~cm}$ do solo esteve a 20,40 e 60 centibares. Stone \& Moreira (1986) sugeriram o reinício da irrigação quando a tensào da água do solo, medida com tensiômetro, atingisse a faixa de 25 a $30 \mathrm{kPa}$ e, Saad et al. (1992) recomendam a irrigação quando o potencial mátrico apresentar valores de -700 a $-300 \mathrm{~cm}$ de água.

O controle da irrigação por aspersão, no sistema convencional, autopropelido e, sobretudo, via pivô central, deve ser feito por meio de metodos precisos, sendo mais utilizados os do tanque evaporimétrico (tanque classe A) e o de tensiômetros associados a curvas de retenção de agua (Peloso et al.. 1996).

Ao avaliarem a otimização do uso da água, Dourado-Neto et al (1992) relataram as vantagens do tensiometro em relação aos demais metodos, por conferir uma boa estimativa do armazenamento de água no solo, alem de ser de simples operacionalização, barato e de fácil tranferência. Tambem Saad et al. (1992) obtiveram um controle eficiente da água disponivel no solo utilizando o metodo do tensiòmetro para controle da irrigação sob pivô central.

Em condições de deficiência hidrica foram observadas maiores densidades radiculares dos cultivares Carioca e BAT 477 nas camadas mais profundas do solo (Guimarães, 1992; Guimarães \& Zimmermann, 1985). Isso implica em economia do uso de carboidratos em detrimento do crescimento radicular nas camadas mais profundas, em que há maior disponibilidade de água (Guimarães, 1992). A eficiència radicular na absorção de água aumenta com a profundidade do solo, provavelmente devido à maior concentração de raizes novas nas camadas mais úmidas e profundas do solo (Stone et al., 1976). Sugere-se que a área superficial e a atividade fisiologica sejam elevadas nas camadas mais profundas, onde as raizes estão em menor quantidade (Follett et al., 1974)

Para o cultivar Carioca foi observada uma eficiencia radicular média de $3,06 \mathrm{~mm}^{3} /$ dia na mesma camada de solo, onde se concentraram $66^{\circ} \%$ do seu sistema 
radicular. A manutenção de absorção de água, sob condições de deficiência hídrica no solo, por meio de uma melhor distribuição do seu sistema radicular, com uma reduçâo maior na camada superficial e menor na camada mais profunda, juntamente com uma maior eficiência radicular nessas camadas, são fatores determinantes das melhores condições hídricas para aquele cultivar (Guimarães, 1992).

White et al. (1990) verificaram que aqueles genótipos com maior densidade radicular apresentaram maior discriminação isotópica do ${ }^{13} \mathrm{C} e$, consequentemente, maiores concentração intercelular de $\mathrm{CO}_{2}$ e produtividade.

Como o estudo da morfologia e do crescimento do sistema radicular das plantas cultivadas, a campo, em geral apresenta um certo grau de dificuldade, hả poucos estudos nessa área em relação à parte aérea. Em muitos trabalhos, realizou-se a avaliação quantitativa das raizes por meio de coletas a diferentes profundidades com cilindros de volume e peso conhecidos, seguidas de separação das raízes por lavagens (Guimarães et al., 1997a).

O método do trado tem sido bastante utilizado por sua simplicidade, baixo custo $\mathrm{e}$ por permitir um grande número de amostragens no campo, sem comprometimento da área amostrada. É um método bem trabalhoso, principalmente quanto à limpeza final das raízes porém, fornece avaliações coerentes em relação aos métodos, por exemplo, de avaliação "de presença e ausência" e de filmagem do perfil com análise direta por meio do software SIARCS (Guimarães et al., 1997b).

Há também outros métodos, relacionados em Guimarães et al. (1997a), como o da avaliação por meio da retirada horizontal de monolitos do solo, que permite integrar os gradientes horizontais e obter uma avaliação mais precisa do desenvolvimento das raizes em profundidade; o da prancha de pregos, com a qual se obtém melhor ilustração da morfologia das raízes no solo; o da relação de notas visuais para diferentes tipos de raizes e o peso desse material seco, particularmente para milho, obtendo-se uma correlação entre o aspecto qualitativo (visual) e o quantitativo (quantidade de raizes secas); o da observação direta a partir de uma trincheira aberta no solo, que fornece informações essencialmente qualitativas e permite o estudo das relações entre o perfil cultural e o enraizamento, bem como o diagnóstico do estado fisico do solo. 


\subsection{Rotação de culturas e adubação verde}

O manejo racional do solo é primordial para o aperfeiçoamento da agricultura, pois a obtenção de elevados índices de produtividade e maior rentabilidade agrícola dependem, fundamentalmente, da manutenção de sua capacidade produtiva.

No Estado de São Paulo, cultivado em sua quase totalidade, o processo de degradação dos solos é acentuado, particularmente pela sua utilização inadequada e pelo seu manejo de maneira imprópria. Segundo Costa (1985), as perdas médias por erosão em áreas cultivadas com o feijoeiro nesse Estado, na safra de 1982/83, foram de 38 tha.

Entende-se como sistema de manejo a associação de práticas agricolas como calagem, rotação de culturas e adubação verde, entre outras, que podem ser utilizadas em uma área de modo a aumentar e manter sua capacidade produtiva. O processo erosivo, um dos mais relevantes problemas da agricultura intensiva no Brasil, é a consequência maior das modificações que os sistemas de manejo provocam no solo, principalmente aquelas relacionadas com sua estrutura, como densidade do solo, porosidade e agregação, que atuam diretamente na infiltração e retenção de água (Castro \& De Maria, 1993). A principal causa da erosão é o impacto direto da gota de água de chuva no solo descoberto, sendo que a maneira mais racional para o seu controle é a interposição de camadas de resíduos vegetais (Wünsche \& Denardin, 1978).

A intensidade de erosão é também influenciada pela textura, pelo teor de matéria orgânica, pela declividade do terreno, pelo sistema de preparo de solo, pelas práticas culturais utilizadas, pela rugosidade superficial do solo, pela qualidade e quantidade de cobertura vegetal e pela própria cultura (Castro \& De Maria, 1993).

A rotação de culturas é uma prática agricola conservacionista antiga e deve ser efetuada de acordo com um planejamento adequado, no qual são considerados diversos fatores, tais como as culturas econômicas predominantes da região, em torno das quais será programada a rotação, além dos fatores de ambiente que influenciarão as culturas escolhidas para a alternância na mesma área (Rosa, 1980; Santos, 1990). Segundo Castro (1956), a rotação de culturas pode ser definida como uma "sucessão recorrente e mais ou menos regular de diferentes cultivos no mesmo terreno", 
Como objetivos previstos para sua utilização tem-se a diversificação da renda; a melhoria do aproveitamento das máquinas e mão-de-obra disponiveis na propriedade; a contribuição para manutenção e melhoria da fertilidade do solo; a diminuição significativa de moléstias, pragas e plantas infestantes; a redução de perdas do solo pelo controle da erosão e o aumento e estabilidade da produtividade das espécies (Mascarenhas \& Tanaka, 1993; Rosa, 1980; Santos et al, 1987; Tomazini, 1987; Viegas \& Machado, 1990), além da manutenção da biodiversidade na área cultivada.

Conforme Derpsch (1984), na sucessão devem ser considerados os efeitos negativos e positivos de uma cultura em relação à outra, mais especificamente os efeitos das substâncias tóxicas; do fornecimento de nutrientes; do incremento de matéria orgânica; na estrutura do solo; sobre a população de microorganismos e umidade residual do solo, assim como do cultivo alternado de culturas para as quais ha diferentes necessidades de mão-de-obra, de máquinas, implementos e de água. em epocas distintas.

$\mathrm{O}$ uso de um sistema de rotação eficiente permite a escolha de periodos de preparo de solo, de semeadura, de tratos culturais e de colheita com vistas à melhor distribuição das exigências de mão-de-obra em relação à monocultura. A escolha de espécies que poderão constituir um sistema de rotaçâo depende de vários fatores, entre os quais incluem-se a peculiaridade para solucionar problemas especificos. como o controle de moléstias radiculares; a finalidade de uso (grâos, forragem ou recobrimento do solo) e, principalmente, os aspectos econômicos (Santos, 1992).

A rotação de culturas é recomendada para o controle de praticamente todas as moléstias do feijoeiro induzidas por fungos, bactèrias e nematóides. Essa prática agricola não chega a erradicar fungos de solo como Rhizoctonia solami e Fusarium solani f. sp. phaseoli, mas permite reduzir o potencial de seu inoculo. Para fungos causadores de podridões radiculares há recomendações de uso da area por 6 a 12 meses com culturas não hospedeiras como o milho e o trigo, em alternância com o feijoeiro, visando a redução da severidade da doença. Para áreas com histórico de danos severos é recomendável um maior tempo de rotação de culturas (Abawi e Pastor Corrales. 1990).

A rotação de culturas pode ser recomendada, ainda para o controle das doenças mofo-branco (Sclerotinia sclerotiorum), mancha-parda-da-folha (Aliernaria 
spp.), mancha angular (Isariopsis griseola), mancha de ascoquita (Ascochyta phaseolorum) e mela em feijoeiro (Thanatephorus cucumeris, fase sexual da $R$. solami), conforme diversos autores mencionados em Vieira et al. (1993).

Sharma et al. (1982) constataram que a manutenção da matéria orgânica do solo é muito importante também para o controle de nematóides, sendo que as leguminosas crotalária (C. juncea L., C. spectabilis, C. paulina e C. grantiana), labelabe, mucuna (preta, anã e cinza), guandu e outras espécies foram altamente eficientes na redução da população ativa de nematóides fitoparasitas e saprófitas. O seu controle pareceu estar mais associado à produção de toxinas pelos adubos verdes do que pela produção de matéria seca, constituindo-se num método muito barato para o controle de nematóides.

Diversos estudos comprovaram a eficiência da utilização de Crotalaria spp., da mucuna preta (Mucuna aterrima Piper \& Tracy) e da mucuna anã (Mucuna deeringiana Bort.) para a redução de população de nematóides (Cameiro \& Carneiro, 1992; Pinto \& Vasconcelos, 1992; Reddy et al., 1986), sendo que a adubação verde com C. paulina, além de possibilitar a diminuição acentuada da população de diversos fitonematóides, também permitiu obter um maior lucro/hectare na cultura do feijoeiro, subseqüentemente (Sharma \& Scolari, 1994).

A cobertura vegetal do solo pode proporcionar efeitos tanto positivos quanto negativos sobre os sistemas de produção. Aqueles são observados no controle de plantas infestantes e da erosão e na oportunidade de semeadura das culturas em sua melhor época. Estes últimos relacionam-se aos efeitos alelopáticos sobre 0 desenvolvimento e sobre a diminuição do rendimento de grãos das culturas em sucessão (Almeida, 1988; Kronstad et al., 1978; Patrick et al., 1964; Santos \& Reis, 1991). Para Almeida (1988), esse efeito relaciona-se diretamente com a quantidade de palha da cultura anterior. No controle de plantas infestantes, Abboud \& Duque (1986) observaram efeitos alelopáticos aparentemente negativos da mucuna preta sobre o feijoeiro e benéficos sobre o milho.

A influência da cultura na proteção do solo depende da densidade de cobertura que lhe é proporcionada, uma vez que as perdas de solo ocorrem 
essencialmente no periodo inicial de crescimento das plantas. A quantidade e a qualidade da cobertura vegetal vai depender da adequação do sistema de rotação ou sucessão de culturas, objetivando a estabilidade produtiva e a redução das perdas de solo pelo controle da erosão (Santos, 1992).

Alguns cereais como aveia, cevada, milho, trigo e triticale apresentam elevada densidade populacional, desenvolvimento relativamente rápido $\mathrm{e}$, depois de desintegrados ou colhidos, deixam residuos abundantes, densos e de decomposição lenta no terreno (Santos et al., 1990). Além disso, as gramineas possuem sistema radicular abundante, que funciona como uma rede, mantendo os agregados do solo, tornando-os mais resistentes à ação do impacto da gota de água da chuva e ao transporte pela enxurrada (Dechen et al.,1981). Os resíduos do feijoeiro, soja, colza e de girassol, por sua vez, são produzidos em pequena quantidade e com elevada percentagem de folhagem, decompondo-se rapidamente e resultando em cobertura desuniforme e pouco densa (Santos et al., 1990).

A matéria orgânica do solo é muito importante para o condicionamento do solo e para o pleno desenvolvimento do feijoeiro, afetando muito significativamente as características fisicas daquele. Além de ser fonte de nutrientes, ao se decompor, permite a formação de uma série de compostos orgânicos complexos, que vão sendo liberados à medida em que são hidrolisados e postos à disposição da planta (Oliveira et al., 1996).

Particularmente nas áreas tropicais e sub-tropicais e, nos sistemas de produção em que há decomposição e queima acelerada dos componentes orgànicos do solo, verifica-se maior predisposição a alteraçôes e variaçôes rápidas que afetam negativamente o desenvolvimento das plantas (Bulisani et al., 1987). Em estudos realizados por Muzilli (1983), observou-se que, tanto em preparo convencional de solo quanto em plantio direto, a camada arável teve seu teor de matéria orgânica aumentado com o tempo de cultivo, sendo similares os efeitos proporcionados pelos dois sistemas de preparo, em esquemas de rotação ou de sucessão.

O fornecimento e ou a conservação de matéria orgànica no solo. com vistas à manutenção ou à elevação da sua fertilidade, compreendem a adição de estercos, compostos, tortas e outros resíduos orgânicos e a utilização da adubação verde e ou da 
rotação de culturas (Bulisani et al., 1987). As leguminosas têm sido utilizadas desde a antiguidade para diversas finalidades, sendo úteis para o controle de molestias, de plantas infestantes e de insetos-praga (Lorenzi, 1984), para a diminuição da erosão do solo (Wischmeier, 1960) ou, ainda, com a finalidade de fornecimento de nitrogênio à cultura subseqüente (Bruulsema \& Christie, 1987; Gallo et al., 1981; Hesterman et al., 1986; Mascarenhas \& Tanaka, 1993; Sutherland et al., 1961).

No Estado de São Paulo foi possivel estabelecer as bases do zoneamento ecológico para o feijoeiro a partir de alguns trabalhos sobre adubaçào verde na cultura dessa leguminosa, quando foram privilegiadas aquelas regiões com maior probabilidade de se obterem elevados rendimentos (Bulisani et al., 1992).

Os resultados mais relevantes em adubação orgânica tèm sido observados quando a fitomassa, especialmente de leguminosas, é incorporada ao solo, procedendo-se à semeadura do feijoeiro (Almeida et al., 1971; Bulisani et al., 1987: Mascarenhas et al., 1967a,b; Miyasaka et al, 1965;1966a,d). Nessa situação, expressam-se com intensidade os efeitos de cobertura da superficie do solo ("mulch"); de maior aeraçào; penetração de raízes; maior capacidade de retenção de água e sensivel redução na variação da temperatura diária do solo. Este último parâmetro, inclusive, pode alcançar amplitudes bastante largas, com valores elevados o suficiente para paralisar o crescimento do feijoeiro, o que ocorre com relativa frequência na safra "da seca"(Bulisani et al.. 1987).

Nos primeiros trabalhos sobre essa pratica agricola em nosso Estado, observou-se que a incorporação de 16 t/ha de fitomassa mista de capim gordura e de soja-perene $(50 / 50 \%)$ imediatamente antes da semeadura do feijoeiro. na safra "das águas", em solo arenoso, além do efeito de cobertura morta de parte da fitomassa deixada sobre a superficie do solo ( $8 \mathrm{t} / \mathrm{ha}$ ), resultou em aumento de $79 \%$ no rendimento dessa leguminosa (Miyasaka et al., 1965).

Miyasaka et al., (1966d) obtiveram um efeito bastante expressivo da adubaçâo verde em feijoeiro, refletido em aumentos da ordem de $39.46,52$ e $91 \%$ no seu rendimento, quando se incorporaram, respectivamente, plantas com 2.5 a 3 meses de idade de labelabe, tefrósia, guandu e crotalária, imediatamente antes da sua semeadura. 
Nos estudos de Mascarenhas et al. (1967b) houve um aumento de 30\% no rendimento do feijoeiro "da seca" semeado imediatamente após a incorporação da fitomassa total ou com extração dos caules de $C$. juncea L., mesmo com redução na população de plantas daquela leguminosa.

Segundo Miyasaka et al. (1967), o efeito da adubação mineral com nitrogênio no feijoeiro foi sempre maior quando se realizou incorporação de matéria orgânica não decomposta de capim-gordura, soja perene e serrapilheira. Mascarenhas et al., (1967a), por sua vez, obtiveram aumentos de 91 e $23 \%$ no rendimento do feijoeiro "da seca", em latossolo vermelho escuro, com incorporação de fitomassa de caupi (Vigna unguicullata), respectivamente na ausência e na presença de nitrogênio mineral.

Em seus estudos, Almeida et al. (1971) observaram aumento de rendimento variando entre 19 e $38 \%$ no feijoeiro "da seca" semeado um mês após a incorporação de 40 a 51 t/ha de fitomassa de $C$. juncea $L$. Nessa mesma época de semeadura, Bulisani et al. (1972) obtiveram aumentos de 82 e $66 \%$ no rendimento com a incorporação de fitomassa respectivamente de soja-perene e de capim-gordura, imediatamente antes da semeadura do feijoeiro. Os autores atribuiram esses resultados positivos à melhoria das condições fisico-químicas do solo, particularmente daquelas relacionadas à aeração. Também foram relatados efeitos positivos da incorporação de fitomassa de soja sobre o rendimento do feijoeiro "das águas", nas mais distintas condições ecológicas do Estado de São Paulo (municípios de Botucatu, Jaú, Mococa, Monte Alegre do Sul, Ribeirão Preto, São Simão e Tietê) e em dois anos de avaliaçôes, sendo verificados alguns resultados superiores a $1.000 \mathrm{~kg} / \mathrm{ha}$ (Almeida et al., 1972).

Ainda no Estado de São Paulo, Almeida et al. (1975) observaram efeitos muito positivos da incorporação de 25 t/ha de fitomassa não decomposta de soja-perene no rendimento do feijoeiro "da seca", particularmente em Pindorama e Ribeirão Preto, independentemente do espaçamento entre-linhas $(0,30$ e 0,40 metro) ou da utilização de adubação mineral NPK

A adubação verde com aveia preta ou nabo forrageiro, em valores absolutos, pode determinar rendimentos mais elevados para as culturas do feijoeiro e da soja. As gramíneas apresentam relação $\mathrm{C} / \mathrm{N}$ superior à das leguminosas, ou seja, a 
decomposição de seus restos vegetais é mais lenta, o que pode facilitar o seu aproveitamento pelas espécies subsequentes (Derpsch et al., 1985).

Também Mello (1986) obteve resultados satisfatónios em seus diversos estudos sobre sistemas de produção envolvendo as culturas do feijoeiro, do milho e da soja, com preparo convencional do solo no Estado de Santa Catarina.

Um exemplo típico de deficiência de incorporação de restos vegetais na cultura do feijoeiro é aquele observado em extensas áreas de cerrado no Brasil Central e no oeste paulista, onde a produtividade das plantas só é razoável em solos que anteriormente receberam fitomassa, particularmente de leguminosas. Esse efeito é tão mais benéfico quanto mais insuficientes forem as condições de cultivo do feịoeiro. Incluem-se como principais fatores de risco a ocorrència de veranicos nos estádios iniciais de desenvolvimento e de temperaturas elevadas na superficie do solo. fatores estes que são atenuados pela presença de materiais orgânicos volumosos em mistura ou sobre a superficie do solo (Bulisani et al., 1987).

Em área correspondente a 300 ha irrigados, em esquema de plantio direto, em Colômbia, São Paulo, vêm sendo utilizadas, com sucesso, as rotaçòes: milho superprecoce ou precoce (julho-dezembro)/soja, cultivar IAC-15 (dezembro-abril)/ aveia-preta e ou trigo (maio-agosto) no primeiro ano; milho (agosto-janeiro)/soja (janeiroabril)/aveia-preta, feijoeiro e ou adubos verdes como a $C$. juncee $L$. e o guandu $\left(2^{8}\right.$ quinzena de abril-julho) no segundo ano, sendo então reiniciado o cicio de rotaçòes (Formiga Júnior, 1995). ${ }^{3}$

Mais recentemente, Arf et al (1996) obtiveram rendimento quase duplicado do feijoeiro quando anteriormente se procedeu à incorporaçào de mucuna preta e também resultados benéficos com a incorporação de labelabe e de milho + mucuna preta. Silveira \& Silva (1996), por sua vez, obtiveram aumento significativo na produtividade do feijoeiro, com as rotações arroz + calopogònio-feijoeiro. milho-feijoeiro e arroz-feijoeiro no primeiro ano; com soja-trigo-soja-feijoeiro-arroz-feijoeiro e arroz + calopogônio-feijoeiro no segundo ano e arroz + calopogônio-feijoeiro e soja-trigo-sojafeijoeiro-arroz-feijoeiro no terceiro ano.

\footnotetext{
${ }^{3}$ Formiga Júnior, J. Fazenda Continental, Colômbia. São Paulo. Comunicaço pessaal. 1995
} 
Como opção de culturas em rotação, em esquema de plantio direto, em latossolo roxo na região de Santa Helena, Goiás, Merola (1997) relaciona as seqüências milho (setembro-fevereiro)/crotalária (fevereiro-abril)/feijoeiro (abril-agosto) no primeiro ano; milho (setembro-fevereiro)/sorgo forrageiro ou milheto (fevereiro-abril)/feijoeiro (abril-agosto) no segundo ano; soja (setembro a janeiro-fevereiro)/sorgo para sementes (fevereiro a julho-agosto) no terceiro ano e soja (setembro-outubro a janeirofevereiro)/milho para sementes (fevereiro-julho) e feijoeiro (julho a setembro-outubro) no quarto ano. Nesse situação agrícola, a fitomassa de crotalária nào é roçada e sim manejada com rolo-faca no sentido da próxima semeadura.

Considerando-se a rotação do ponto de vista econòmico. Martin et al. (1984) obtiveram aumento no rendimento de culturas com o uso dessa prática agricola. Conforme mencionado em Calegari (1992), concluiu-se que a cultura da aveia-preta antecedendo a do feijoeiro e da soja, assim como a de nabo forrageiro antecedendo a do feijoeiro ou a do milho e, ainda, a de tremoço-branco antecedendo a do milho sào alternativas mais econômicas do que a sucessão soja-trigo.

Diante do exposto, verifica-se a diversidade de resultados, alguns deles até mesmo contraditórios, no rendimento do feijoeiro em esquema de rotaçào de culturas. Isto evidencia a necessidade e, sobretudo, a importància de realização de experimentação, como a proposta no presente estudo, com vistas à definição tanto de culturas mais adequadas, agronomica e economicamente, em situações agricolas especificas, quanto de parâmetros fitotécnicos relacionados à obtenção de resultados positivos nestas mesmas condições. 


\section{MATERIAL E MÉTODOS}

\subsection{Local, clima e solo}

O presente trabalho foi desenvolvido a campo, no periodo compreendido entre 25 de maio de 1992 a início de janeiro de 1996, na Estação Experimental do Instituto Agronômico do Estado de São Paulo/IAC, em Ribeirão Preto, São Paulo, localizada a $21^{\circ} 11^{\prime}$ de latitude sul e $47^{\circ} 48^{\prime}$ ' de longitude oeste e altitude de 621 metros.

O clima da região é do tipo Aw, definido como tropical de baixa altitude, com verão chuvoso e inverno seco, com temperatura média mensal nunca inferior a $18^{\circ} \mathrm{C}$ e com precipitação pluvial do mês mais seco inferior a $30 \mathrm{~mm}$ e temperatura média do mês mais quente superior a $22^{\circ} \mathrm{C}$. A sucessão de periodos umidos e secos se faz abruptamente, marcando com nitidez duas estações: uma seca "de inverno" (23\% da precipitação anual), que se estende de abril a setembro, apresentando nos meses de junho, julho e agosto, precipitações inferiores a $30 \mathrm{~mm}$ e outra chuvosa "de verào", que se estende de outubro a março (77\% da precipitaçào anual) (Oliveira \& Noniz, 1975).

A precipitação pluvial anual é de aproximadamente $1.400 \mathrm{~mm}$ e a evapotranspiração potencial de $1.050 \mathrm{~mm}$, com excedente hídrico de $459 \mathrm{~mm}$ e deficiência hidrica de $108 \mathrm{~mm}$. Os dados meteorológicos relativos ao periodo de desenvolvimento da cultura do feijoeiro e coletados no Posto Agrometeorológico localizado na Estação Experimental do IAC estão na tabela 1.

O solo está classificado como latossolo roxo e sua composição granulométrica foi determinada pelo método da "pipeta" modificado por Grohmann \& Raij (1974) e disperso com $\mathrm{NaOH}$ a $0,1 \mathrm{~N}$, a partir de amostras compostas de vinte pontos, tomadas ao acaso, em três profundidades na area experimental (tabela 2). 
Tabela 1: Temperaturas máxima, mínima e média e precipitação pluvial obtidas no posto meteorológico da Estação Experimental do Instituto Agronômico, em Ribeirão Preto, São Paulo, em períodos decendiais de julho a novembro de 1993, agosto a novembro de 1994 e setembro de 1995 a janeiro de 1996.

\begin{tabular}{|c|c|c|c|c|c|}
\hline \multirow[t]{2}{*}{ Mês/Ano } & \multirow[t]{2}{*}{ Decêndio } & \multicolumn{3}{|c|}{ Temperatura } & \multirow[t]{2}{*}{ Chuva } \\
\hline & & Máxima & Mínima & Média & \\
\hline & & & $-{ }^{\circ} \mathrm{C}-$ & & $-\mathrm{mm}$ \\
\hline \multirow{3}{*}{ Julho/93 } & 1 & 28,2 & 13,4 & 20.8 & 0 \\
\hline & 2 & 25,1 & 13,1 & 19.1 & 0.6 \\
\hline & 3 & 26,4 & 12,7 & 19.6 & 0 \\
\hline \multirow{3}{*}{ Agosto/93 } & 1 & 28,1 & 12,4 & 20.2 & 1.6 \\
\hline & 2 & 24,6 & 11,9 & 18.3 & 30.1 \\
\hline & 3 & 28,7 & 14,2 & 21.4 & 11.5 \\
\hline \multirow{3}{*}{ Setembro/93 } & 1 & 30,7 & 16,7 & 23.7 & 92 \\
\hline & 2 & 28,4 & 15,4 & 21.9 & 14.6 \\
\hline & 3 & 28,0 & 17,9 & 23,0 & 63.4 \\
\hline \multirow{3}{*}{ Outubro/93 } & 1 & 29,7 & 17,1 & 23.4 & 1.6 \\
\hline & 2 & 31,6 & 18,1 & 24.9 & 42,9 \\
\hline & 3 & 30,3 & 19,2 & 24.8 & $\$ 4.1$ \\
\hline \multirow[t]{2}{*}{ Novembro/93 } & 1 & 32,2 & 19.2 & $25=$ & 13.5 \\
\hline & 1 & $-\overline{2}, \overline{7}$ & 10,1 & $\overline{18} . \overline{9}$ & $\overline{8} . \overline{3}$ \\
\hline \multirow{2}{*}{ Agosto/94 } & 2 & 28,9 & 12,8 & 20.8 & 10.6 \\
\hline & 3 & 32,5 & 14,0 & 232 & 11.0 \\
\hline \multirow{3}{*}{ Setembro/94 } & 1 & 32,0 & 13,6 & 22.8 & 0 \\
\hline & 2 & 33,1 & 16,2 & $24:-$ & 0 \\
\hline & 3 & 33,0 & 19,4 & 26.2 & 1.4 \\
\hline \multirow{3}{*}{ Outubro/94 } & 1 & 34,1 & 19.2 & $26 .-$ & 0.5 \\
\hline & 2 & 34,1 & 20,2 & 26.5 & 0.5 \\
\hline & 3 & 30,5 & 19,6 & 25.0 & 90.1 \\
\hline \multirow[t]{2}{*}{ Novembro/9 94} & 1 & 33,7 & 20.7 & 272 & 32.0 \\
\hline & $i$ & 31,2 & $-15,7$ & $-23,5$ & $0^{-}$ \\
\hline \multirow[t]{2}{*}{ Setembro/95 } & 2 & 31,7 & 17,4 & 24,5 & 19,3 \\
\hline & 3 & 30.2 & 18,0 & 24,1 & 17.0 \\
\hline \multirow{3}{*}{ Outubro/95 } & 1 & 31,9 & 18,6 & 25,3 & 9.8 \\
\hline & 2 & 27,8 & 17,4 & 22,6 & 102.2 \\
\hline & 3 & 28,0 & 16,9 & 22.4 & 14.2 \\
\hline \multirow{3}{*}{ Novembro/95 } & 1 & 30,4 & 17.4 & 23.9 & 28.0 \\
\hline & 2 & 28,5 & 18,5 & 23.5 & 32.4 \\
\hline & 3 & 30,7 & 17,9 & 243 & 22.7 \\
\hline \multirow{3}{*}{ Dezembro/95 } & 1 & 32,6 & 18,9 & 25.7 & 1.2 \\
\hline & 2 & 28,8 & 20,1 & 245 & 1.4 .1 \\
\hline & 3 & 28,7 & 19.2 & 24.0 & 123.3 \\
\hline Janeiro/96 & 1 & 27.7 & 19.6 & 23.6 & 191.1 \\
\hline
\end{tabular}


Tabela 2: Composição granulométrica e análise textural de amostra de latossolo roxo utilizada em experimento na Estação Experimental do Instituto Agronômico, Ribeirão Preto, São Paulo. 1992.

\begin{tabular}{|c|c|c|c|c|c|c|c|}
\hline \multirow{2}{*}{$\begin{array}{l}\text { Profun- } \\
\text { didade }\end{array}$} & \multicolumn{7}{|c|}{ Teores } \\
\hline & $\begin{array}{l}\text { Areia } \\
\text { grossa }\end{array}$ & $\begin{array}{l}\text { Areia } \\
\text { fina }\end{array}$ & Argila & Silte & $\begin{array}{c}\text { Densidade } \\
\text { aparente }\end{array}$ & $\begin{array}{c}\text { Densidade } \\
\text { real }\end{array}$ & Class \\
\hline$--\mathrm{cm}-$ & & & & $\bar{n}$ & 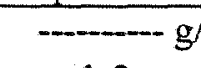 & $\mathrm{cm}^{2}-$ & \\
\hline $0-20$ & 2,9 & 11,7 & 57,1 & 28,3 & 1,2 & 2.9 & \\
\hline $20-40$ & 2,0 & 11,9 & 61, & 25,1 & 1,2 & 2.9 & Muito argilosa \\
\hline $40-60$ & 2,3 & 11,6 & 63,2 & 22,9 & 1,2 & 2.9 & Muito argilosa \\
\hline
\end{tabular}

\subsection{Tratamentos e cultivares utilizados}

Os esquemas de rotação compreenderam quatro ciclos de cultivo do feijoeiro IAC-Carioca (Carioca $80 \mathrm{SH}$ ), de hábito de crescimento indeterminado. tipo III, sob irrigação, de maio a janeiro, seguido por milho precoce, hibrido duplo C -701 , de dezembro a abril e, posteriormente, por pousio, milho híbrido C-701 e pelos adubos verdes aveia preta (Avena strigosa Schieb.), Crotalaria juncea L. cultivar IAC-1, guandu [Cajamus cajan (L.) Millsp.], cultivar IAC-Fava Larga e mucuna preta (Afucuna aterrima), de março a agosto como segue: Tratamento 1 = Feijoeiro-Milho-Pousio: Tratamento 2 = Feijoeiro-Milho-Milho; Tratamento 3 = Feijoeiro-Milho-Aveia Preta; Tratamento 4 = Feijoeiro-Milho-Crotalaria juncea, Tratamento 5 = Feijoeiro-MilhoGuandu; Tratamento 6 = Feijoeiro-Milho-Mucuna Preta.

\subsection{Delineamento experimental e análise estatística}

O delineamento experimental adotado foi o de blocos ao acaso com os seis tratamentos e seis repetições, perfazendo 36 parcelas e $5.480 \mathrm{~m}^{2}$ de area total. A distribuição dos tratamentos em cada bloco foi realizada no primeiro ano e mantida em todos os anos do experimento. 
Cada parcela foi constituída de doze linhas de 30,0 metros de comprimento, espaçadas de 0,50 metro entre si, com uma área de $180,0 \mathrm{~m}^{2}$ e área útil de $30,0 \mathrm{~m}^{2}$, correspondendo a 6 linhas de 10,0 metros de comprimento. Apenas para a cultura do milho as parcelas tiveram seis linhas de 30,0 metros de comprimento, espaçadas 1,0 metro entre si.

O desenvolvimento do sistema radicular foi analisado como parcela subdividida em que as parcelas corresponderam aos tratamentos $e$ as sub-parcelas às diferentes profundidades. Os dados foram comparados pelo teste de Duncan a $5 \%$, sendo que aqueles obtidos em percentagem foram primeiramente transformados em arcoseno de $\sqrt{ } \%$ (Pimentel-Gomes, 1984).

Foram realizadas análises de correlação simples entre algumas características, em cada ano da experimentação, realizando-se o ajuste de equaçôes aos dados experimentais por meio de programa computacional (Zullo Jr. \& Arruda. 1987).

\subsection{Manejo do solo e das culturas}

O solo foi preparado pelo sistema convencional, com uma araçào (arado de discos em 1992 e 1993 e de aiveca em 1994 e 1995) seguida de gradagem niveladora. tendo recebido cerca de 2,0 t/ha de calcário dolomítico para manter a saturaçào por bases a $60 \%$, em uma áunica vez, no ano anterior ao início do presente estudo. A operação de semeadura das culturas foi mecanizada, sendo que o feijoeiro irrigado foi semeado uma semana após o corte e incorporação da fitomassa das plantas de cobertura.

A adubação mineral foi feita de acordo com a necessidade de cada cultura, corforme Raij et al.(1985). Na cultura do feijoeiro esta constou da aplicação de 16, 56 e $32 \mathrm{~kg} / \mathrm{ha}$ de $\mathrm{N}, \mathrm{P}_{2} \mathrm{O}_{5}$ e $\mathrm{K}_{2} \mathrm{O}$, respectivamente, na forma de $400 \mathrm{~kg} / \mathrm{ha}$ da formula de adubo 04-14-08 e, ainda, de $50 \mathrm{~kg} / \mathrm{ha}$ de nitrogênio na forma de sulfato de amònio, em cobertura, aos 20 dias após a semeadura, para manutenção dos niveis de fertilidade constatados na análise química prévia do solo. As demais culturas. à exceçào do milho, não receberam adubação química. 
A cultura do feijoeiro recebeu os tratos culturais recomendados pela pesquisa (Bulisani \& Almeida, 1987), constando de capinas manuais (duas a três durante o seu ciclo), de aplicação de fungicidas e inseticidas e de irrigações, sempre que necessário. Antes da implantação do experimento a área total foi cultivada com a cultura do milho, de setembro de 1991 a fevereiro de 1992.

As datas de semeadura e de colheita do feijoeiro estào relacionadas na tabela 3. Na programação inicial, o feijoeiro seria cultivado no inverno, de abril/maio a julho/agosto, entretanto, anualmente houve um atraso nas datas de semeadura previamente estabelecidas e, conseqüentemente, das demais culturas envolvidas nos esquemas de rotação. Com isso, algumas espécies, incluindo-se o feijoeiro, foram estabelecidas em condições climáticas nem sempre as mais favoraveis ao seu desenvolvimento. Desse modo, o milho que sucedeu ao feijoeiro foi semeado em 05/10/92, 17/11/93 e 02/12/94 e colhido, respectivamente em 25/02/93, 28/03/94 e 11/04/95. O milho e os adubos verdes que antecederam o feijoeiro foram semeados em 23/03/93, 08/04/94 e 25/04/95 e colhidos, respectivamente, em 23/07/93, 27/07/94 e $06 / 09 / 95$.

A fitomassa produzida pelas culturas que antecederam o feijoeiro, bem como da vegetação espontânea no pousio, foi roçada e incorporada por ocasiào do preparo do solo para aquela leguminosa (tabela 4). As culturas graniferas foram colhidas manualmente, incluindo-se o feijoeiro.

Tabela 3: Datas de semeadura, florescimento e colheita do feijoeiro após a rotação com milho/milho e adubos verdes no periodo 25/05/1992 a 07/01/1996, na Estação Experimental do Instituto Agronômico, em Ribeirão Preto, São Paulo.

\begin{tabular}{lccc}
\hline $\begin{array}{l}\text { Ciclo da } \\
\text { rotação }\end{array}$ & Data de semeadura & $\begin{array}{c}\mathbf{5 0 \%} \text { de } \\
\text { forescimento }\end{array}$ & Data de colheita \\
\hline Início & $25 / 05 / 92$ & $20 / 07 / 92$ & $10 / 09 / 92$ \\
$\mathbf{1}^{\mathbf{0}}$ Ano & $27 / 07 / 93$ & $27 / 09 / 93$ & $03 / 11 / 93$ \\
$\mathbf{2}^{\mathbf{0}}$ Ano & $08 / 08 / 94$ & $06 / 10 / 94$ & $11 / 11 / 94$ \\
$\mathbf{3}^{\mathbf{o}}$ Ano & $27 / 09 / 95$ & $27 / 11 / 95$ & $07 / 01 / 96$ \\
\hline
\end{tabular}


Tabela 4: Fitomassa verde de culturas antecedendo o feijoeiro em rotação. Ribeirão Preto, São Paulo. 1993, 1994 e 1995.

\begin{tabular}{lrrr}
\hline Cultura & 1993 & 1994 & 1995 \\
\hline Pousio ${ }^{(1)}$ & 6,0 & 5,3 & 5,5 \\
Milho & 29,0 & 19,0 & 23,2 \\
Aveia preta & 18,0 & 15,1 & 10,9 \\
Crotalária júncea & 26,4 & 22,4 & 14,0 \\
Guandu & 10,5 & 8,8 & 5,5 \\
Mucuna preta & 19,2 & 21,0 & 17,7 \\
\hline
\end{tabular}

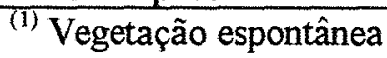

\subsection{Manejo da irrigação}

Para o manejo da irrigação foram utilizados tensiòmetros com manômetro de mercúrio. No local do experimento foram instaladas cinco estaçôes tensiométricas, constando cada uma de seis tensiômetros, sendo dois a $15 \mathrm{~cm}$, dois a $30 \mathrm{~cm}$ e dois a 45 $\mathrm{cm}$ da superficie do solo. O manejo propriamente dito das irrigaçōes foi baseado na leitura dos dois tensiômetros instalados a $15 \mathrm{~cm}$ e o momento de aplicaçào da água foi definido quando o potencial da água no solo atingiu 0,05 MPa de tensào (Arruda, 1987; Bernardo et al., 1970; Bulisani et al., 1987; Daker, 1984). Os demais tensiômetros tiveram por objetivo o controle da frente de molhamento do solo.

\subsection{Parâmetros avaliados}

Para o presente estudo, os parâmetros foram avaliados sempre na cultura do feijoeiro, nos anos agrícolas de 1993, 1994 e 1995, conforme descritos a seguir:

\subsubsection{Avaliações de solo}

\subsubsection{Avaliações químicas}

Antes da instalação do experimento realizou-se uma amostragem de solo na área, na profundidade de $0-20 \mathrm{~cm}$, em pontos representativos tomados ao acaso. Os resultados estão relacionados na tabela 5 . 
Tabela 5: Teores de nutrientes em amostra de latossolo roxo utilizado em experimento, na profundidade de 0-20 cm. Ribeirão Preto, São Paulo, 1992.

\begin{tabular}{|c|c|c|c|c|c|c|c|c|c|}
\hline $\begin{array}{r}\text { Matéria } \\
\text { orgânica }\end{array}$ & pH & $\mathbf{P}$ & $\mathbf{K}$ & $\mathrm{Ca}$ & $\mathbf{M g}$ & $\mathbf{H}+\mathbf{A} \mathbf{l}$ & $S$ & $T$ & V \\
\hline$-\mathrm{g} / \mathrm{dm}^{3}-$ & & $\mathrm{mg} / \mathrm{dm}^{3}$ & & & $=m$ & $\mathrm{~d} d \mathrm{dm}$ & & & $\%$ \\
\hline 38,0 & 5,4 & 54,0 & 3,7 & 46,8 & 12,5 & 35,0 & 63,5 & 98,59 & 64,3 \\
\hline
\end{tabular}

A fertilidade do solo foi determinada anualmente, em cada tratamento, em amostras compostas coletadas em cinco sub-amostras por parcela, no florescimento do feijoeiro (estádio R6), nas profundidades de 0-20, 20-40 e 40-60 cm. As análises foram realizadas conform metodologia descrita por Raij et al. (1987) e as unidades estão expressas no Sistema Internacional (Cantarella \& Andrade, 1992).

\subsubsection{Avaliações físicas}

\subsection{Densidade do solo}

A densidade do solo foi determinada com quatro repetições em todos os tratamentos, a $0-20 \mathrm{~cm}$ e a $20-40 \mathrm{~cm}$, ao final do experimento, como indicadora de variação no condicionamento do espaço poroso a agregação nos sistemas de cultivo. As amostras de solo foram coletadas por meio de anéis volumétricos de $250 \mathrm{~cm}^{3}$, sendo posteriormente secas em estufa elétrica com ventilação forçada a $105^{\circ} \mathrm{C}$ e pesadas para $\mathrm{o}$ cálculo da relação massa/volume do solo (Camargo et al., 1986).

\subsection{Avaliação do perfil de resistência à penetração}

A avaliação do perfil de resistência à penetração foi realizada em cada tratamento, por meio de testes com penetrômetros de impacto, modelo IAA/PLANALSUCAR (Stolf et al., 1983), por ocasião do florescimento das plantas do feijoeiro e inicio de formação de vagens (estádio R7), de 1993 a 1995, com quatro a oito repetições. Os resultados foram analisados segundo Stolf (1991) e Stolf et al.(1983). 


\subsection{Velocidade de infiltração básica (VIB)}

A velocidade de infiltração básica foi avaliada em janeiro de 1996 por meio de infiltrômetro de nivel constante, constituído por um anel metálico de 1,20 metro de diâmetro, conforme recomendação de Bower (1986), para reduçào de erros, com 0,20 metro de altura e um dispositivo para alimentação de água e determinação da lâmina infiltrada. $\mathrm{O}$ aparelho foi instalado ao término do experimento, na profundidade de $10 \mathrm{~cm}$, com quatro repetições por tratamento. $\mathrm{O}$ anel foi preenchido com água, sendo mantido um nivel máximo de $5 \mathrm{~cm}$ de altura.

\subsubsection{Avaliações na planta}

\subsubsection{Teor de macronutrientes}

Para a determinação do teor de macronutrientes na parte aerea. coletaramse ao acaso, por parcela, em 1994 e 1995, todas as folhas de dez plantas de feijoeiro na fase de florescimento pleno e início de formação de vagens (inicio do estádio R7), com seis repetições por tratamento, conforme os critérios de amostragem recomendados por Trani et al. (1983). As amostras foram analisadas segundo metodologia descrita por Bataglia et al. (1983) e, à exceção do nitrogênio, para os demais nutrientes utilizou-se o ácido clorídrico como extrator, conforme variaçâo proposta por Mịasawa et al. (1984).

\subsubsection{Cobertura vegetal do solo}

A cobertura vegetal do solo foi determinada pelo metodo da corda (Sloneker \& Modenhauer, 1977), na fase de florescimento pleno e inicio de formação de vagens no feijoeiro (estádio R7), em 1994 e 1995. Utilizou-se para tanto a identificaçào

de pontos sem ou com vegetação, numa corda graduada de $10 \mathrm{em} 10 \mathrm{~cm}$. esticada transversalmente às linhas de semeadura, com duas repetições por parcela com doze amostragens por tratamento. 


\subsubsection{Quantidade de matéria seca}

A quantidade de matéria seca total na parte aerea foi determinada em plantas de feijoeiro cortadas rente à superficie do solo, em área de $1.0 \mathrm{~m}^{2}$, equivalente a duas linhas de 1,0 metro de comprimento, espaçadas 0,50 metro entre si, tomadas ao acaso, no florescimento pleno e início de formação de vagens do feijoeiro (estádio R7), com seis repetições por tratamento, em 1994 e 1995. A quantidade de matéria seca foi determinada após secagem em estufa elétrica com ventilação forçada a $80^{\circ} \mathrm{C}$, até valor constante.

\subsubsection{4. Índice de área foliar (IAF)}

$O$ indice de área foliar (IAF) foi determinado em plantas de feijoeiro amostradas em 2,0 metros lineares por parcela, com seis repetiçoes, no florescimento pleno e início de formação de vagens (estádio R7), em 1994 e 1995. Imediatamente após a coleta as plantas foram levadas ao laboratório, onde se mediu a area foliar pelo método de disco de folha de área conhecida, utilizando-se um vazador de $1.1 \mathrm{~cm}$ de diàmetro para amostragem de 100 discos por repetição.

\subsubsection{Altura média de plantas}

A altura média foi obtida, medindo-se 20 plantas amostradas ao acaso no canteiro, com régua graduada em $\mathrm{cm}$, em seis repetiçòes por tratamento. na fase de enchimento de vagens do feijoeiro (estádio R8). Nessa avaliaçào mediu-se a altura desde a superficie do solo até a extremidade da guia.

\subsubsection{Avaliação do sistema radicular}

O sistema radicular foi avaliado segundo a metodologia de Gottingen (Bohm, 1979). Esta avaliação foi realizada em 1994 e 1995. no florescimento pleno e inicio de formação de vagens nas plantas (estádio R7). utilizando-se um trado tipo caneca de bordo serrilhado e com $7 \mathrm{~cm}$ de diâmetro, descrito por Fujiwara et al. (1994)

Foram coletadas amostras de solo com raizes em uma area a cerca de 15 $\mathrm{cm}$ da linha de semeadura, de $10 \mathrm{em} 10 \mathrm{~cm}$ ate $60 \mathrm{~cm}$ de profundidade. conforme 
determinado em feijoeiro, por Avilan-Rovira (1975) e Pires et al. (1991), com quatro repetições por tratamento. No ano de 1993 não foram amostrados os canteiros anteriormente cultivados com guandu. As amostras foram acondicionadas individualmente em sacos plásticos, com uma solução alcoólica a 5\% para desagregação dos torrões, e mantidas em repouso por 24 horas. Após sucessivas lavagens, fez-se a separação das raízes em peneiras com malha de 0,5 mm de largura (Bohm, 1979). As impurezas foram retiradas manualmente com uma pinça, antes da secagem a $60^{\circ} \mathrm{C}$, em estufa por 48 horas, sendo então estimada a densidade de comprimento das raizes finas pelo método de intersecção de linhas (Tennant, 1975). Foram consideradas como raizes finas, ou absorventes, aquelas com diâmetro inferior a pelo menos $1 \mathrm{~mm} e$ abundantemente dotadas de pelos radiculares (Portas, 1970). Considerou-se como profundidade efetiva do sistema radicular aquela em que se concentraram pelo menos $80 \%$ do total das raizes finas (Arruda, 1989; Noordwijk, 1983), por meio de interpolações entre a somatória dos valores de duas profundidades consecutivas.

\subsubsection{Estande final}

O estande de plantas foi determinado por ocasião da colheita. sendo contadas as plantas amostradas para rendimento de grãos, em area útil de $9,0 \mathrm{~m}^{2}$. convertendo-se os dados para valores de mil plantas/hectare

\subsubsection{Rendimento de grãos}

No início do experimento, em 1992, determinou-se o rendimento de grãos em sub-áreas representativas de $9,0 \mathrm{~m}^{2}$ cada, tomadas ao acaso na área experimental total. Nos anos de 1993, 1994 e 1995, esse parâmetro foi determinado em area útil de 9,0 $\mathrm{m}^{2}$ por canteiro, correspondendo a seis linhas de 3,0 metros de comprimento, espaçadas 0,50 metro entre si, perfazendo seis repetições por tratamento. As plantas foram colhidas e trilhadas manualmente e os grãos pesados, corrigindo-se a umidade para $13 \%$. Os dados foram convertidos em $\mathrm{kg} / \mathrm{ha}$. 


\section{RESULTADOS E DISCUSSÃO}

\subsection{Fertilidade do solo}

As características químicas do solo, componentes da sua fertilidade, observadas anualmente em cada tratamento estão relacionados nas tabelas 6,7 e 8 , respectivamente para os anos agrícolas de 1993, 1994 e 1995

Tabela 6: Características químicas de um latossolo roxo, em três profundidades, cultivado com feijoeiro em rotação de culturas. Ribeirão Preto, SP, 1993.

\begin{tabular}{|c|c|c|c|c|c|c|c|c|c|c|c|}
\hline $\begin{array}{l}\text { Trata- } \\
\text { mento }\end{array}$ & $\begin{array}{c}\text { Profun- } \\
\text { didade }\end{array}$ & 0 & & $\mathbf{P}$ & $\mathbf{K}$ & $\mathrm{Ca}$ & Mg & $+A I$ & $\mathbf{s}$ & $T$ & $v$ \\
\hline \multirow{4}{*}{ Pousio } & $\mathrm{cm}$ & $\mathrm{g} / \mathrm{dm}^{3}$ & & $\mathrm{mg} / \mathrm{dm}^{3}$ & & & & & & & $\%$ \\
\hline & $0-20$ & 33,0 & 5,1 & 36,0 & 2,1 & 28,0 & 9.0 & 43.0 & 39.1 & 82.1 & 47.7 \\
\hline & $20-40$ & 30,0 & 5,1 & 36,0 & 2,3 & 31,0 & 10.0 & 43,0 & 43.0 & 86,0 & 50,0 \\
\hline & $40-60$ & 25,0 & 5,2 & 23,0 & 1,4 & 30.0 & 8.0 & 34.0 & 39.0 & 73.0 & 54.0 \\
\hline \multirow{3}{*}{ Milho } & $0-20$ & 32,0 & 5,1 & 42,0 & 2,4 & 33.0 & 10.0 & 43.0 & 45.0 & 88.0 & 1.0 \\
\hline & $20-40$ & 26,0 & 5,2 & 36,0 & 1,7 & 29,0 & 6. & 34.0 & 40.0 & 74.0 & 54,0 \\
\hline & $40-60$ & 23,0 & 5,3 & 22,0 & 1,6 & 26,0 & 9.0 & 34.0 & 36.6 & 71.6 & 51.1 \\
\hline \multirow{4}{*}{ preta } & $0-2$ & 33,0 & 4,9 & 38,0 & 2,3 & 34,0 & 9,0 & 52,0 & 45.0 & 97.0 & 47,0 \\
\hline & $20-40$ & 26,0 & 5,0 & 20,0 & 1,9 & 27,0 & 8.0 & 43,0 & 37.0 & 80.0 & 46,0 \\
\hline & $40-60$ & 18,0 & 5,3 & 16,0 & 1,1 & 27.0 & 7.0 & -31.0 & 35.0 & 66,0 & 53.0 \\
\hline & 0 & 30,0 & 5,0 & 51,0 & 3,5 & 39,0 & 10,0 & 7,0 & 53.0 & 99.0 & 53,0 \\
\hline \multirow{3}{*}{ juncea } & 20 & 26,0 & 5,1 & 23,0 & 2,3 & 33,0 & 9.0 & 43,0 & 44.0 & 87.0 & 51,0 \\
\hline & $40-60$ & $20,0$. & $-5,1$ & 11,0 & $-1,9$ & 25,0 & 7.0 & -34.0 & 34.0 & 68.0 & 50,0 \\
\hline & $0-20$ & 36,0 & 5,0 & 38,0 & 2,5 & 37,0 & 10,0 & 47.0 & 50.0 & 97,0 & 51.0 \\
\hline \multirow{2}{*}{$\begin{array}{l}\text { Mucuna } \\
\text { preta }\end{array}$} & $20-40$ & 25,0 & 5,3 & 20,0 & 1,7 & 34,0 & 12.0 & 34,0 & 48.0 & 82.0 & 58,0 \\
\hline & $40-60$ & 19,0 & 5,4 & 14,0 & 1,1 & 26.0 & 8.0 & 31.0 & 35.1 & 66.1 & 53.1 \\
\hline
\end{tabular}


Tabela 7: Características químicas de um latossolo roxo, em três profundidades, cultivado com feijoeiro em rotação de culturas. Ribeirão Preto, SP, 1994.

\begin{tabular}{|c|c|c|c|c|c|c|c|c|c|c|c|}
\hline $\begin{array}{l}\text { Trata- } \\
\text { mento }\end{array}$ & $\begin{array}{l}\text { Profun- } \\
\text { didade }\end{array}$ & M.O. & $\mathrm{H}_{2}$ & $\mathbf{P}$ & $\mathbf{K}$ & $\mathrm{Ca}$ & $\mathbf{M g}$ & $\mathrm{H}+\mathrm{Al}$ & $s$ & $\mathrm{~T}$ & $v$ \\
\hline & $\mathrm{cm}$ & $\mathrm{g} / \mathrm{dm}^{3}$ & & $\mathrm{mg} / \mathrm{dm}^{3}$ & & & -1 & $d d \mathrm{dm}^{3}-$ & & & $\%$ \\
\hline & $0-20$ & 31,7 & 4,9 & 36,8 & 2,5 & 29,6 & 8,9 & 42,5 & 41.0 & 83,5 & 49,1 \\
\hline \multirow[t]{3}{*}{ Pousio } & $20-40$ & 28,8 & 5,1 & 28,0 & 2,2 & 28,9 & 9,3 & 38,9 & 40,4 & 79,3 & 50,9 \\
\hline & $40-60$ & 18,1 & 5,2 & $-19,4$ & 1,3 & 24,0 & 8.2 & 33,3 & 33.5 & 66.8 & 50,1 \\
\hline & $0-20$ & 31,4 & 5,1 & 37,3 & 2,4 & 32,6 & 9,5 & 43.9 & 44.5 & 8.4 & 50,3 \\
\hline \multirow[t]{3}{*}{ Milho } & $20-40$ & 25,1 & 5,1 & 34,1 & 1,7 & 30,0 & 9 & .5 & 40.8 & 78.3 & 52.1 \\
\hline & $40-60$ & $-18,5$ & $-5,3$ & $2 \underline{2}, \underline{8}$ & 1,4 & 26.5 & 9.2 & 33.4 & 37.1 & 70.5 & 52.6 \\
\hline & $0-20$ & 32,0 & 4,9 & 37,2 & 2,4 & 32,3 & 8,8 & 49.8 & 43.5 & 93.3 & 46,0 \\
\hline Aveia & $20-40$ & 24,9 & 5,0 & 21,4 & 1,8 & 29,5 & 8,6 & 41.7 & 39.9 & 81.6 & 48,0 \\
\hline \multirow[t]{2}{*}{ preta } & $40-60$ & $-16,1$ & 5,2 & 1 & 1,1 & 26,7 & 8,3 & 9 & 6.1 & .0 & .0 \\
\hline & $0-20$ & 31,0 & 5,0 & 47,7 & 2,9 & 37,1 & 9.6 & 45.5 & 49.6 & 95.1 & 52,2 \\
\hline Crotal. & $20-40$ & 25,2 & 5,1 & 23,2 & 2,3 & 33,3 & 9,1 & 37,9 & 4.7 & 82,6 & 54,0 \\
\hline \multirow[t]{2}{*}{ juncea } & $40-60$ & 19,1 & 5,2 & $15, \underline{3}$ & $-1,5$ & 30,0 & 8.0 & 29.8 & -39.5 & 69.3 & 56.0 \\
\hline & $0-20$ & 31,5 & 4,7 & 36,5 & 2,5 & 30,2 & 7,7 & 48.6 & 40.4 & 89.0 & 45,0 \\
\hline \multirow[t]{3}{*}{ Guandu } & $20-40$ & 26,8 & 4,9 & 21,9 & 1,9 & 29.8 & 8,1 & 41.0 & 39.8 & 80.8 & 49,0 \\
\hline & $40-60$ & 18,4 & 5,2 & 17,0 & 1,3 & 28.4 & 7.6 & 31.8 & 37.3 & 69.1 & 53.0 \\
\hline & $0-20$ & 34,2 & 5,0 & 37,8 & 2,6 & 35.4 & 9,0 & 46.6 & $\$ 7,0$ & 93.6 & 50,0 \\
\hline Mucuna & $20-40$ & 24,8 & 5,1 & 21,7 & 1,8 & 34.2 & 9,4 & 34.1 & 45,4 & 79.5 & 57.0 \\
\hline preta & $40-60$ & 18,3 & 5,4 & 16,0 & 1.4 & 29.3 & 7.9 & 29.5 & 38.6 & 68.1 & 56.0 \\
\hline
\end{tabular}


Tabela 8: Características químicas de um latossolo roxo, em três profundidades, cultivado com feijoeiro em rotação de culturas. Ribeirão Preto, SP, 1995.

\begin{tabular}{|c|c|c|c|c|c|c|c|c|c|c|c|}
\hline $\begin{array}{l}\text { ata- } \\
\text { ento }\end{array}$ & $\begin{array}{c}\begin{array}{c}\text { Profun- } \\
\text { didade }\end{array} \\
\end{array}$ & M.o. & $\begin{array}{c}\mathrm{pH} \\
\mathrm{CaCl}_{2} \\
\end{array}$ & $\mathbf{P}$ & K & $\mathrm{Ca}$ & $\mathbf{M g}$ & $\mathbf{H}+\mathbf{A I}$ & s & $\mathrm{T}$ & $v$ \\
\hline & $\mathrm{cm}$ & $\mathrm{g} / \mathrm{dm}^{3}$ & & $\mathrm{mg} / \mathrm{dm}^{3}$ & & & $-\mathrm{mm}$ & $\mathrm{l} / \mathrm{dm^{3 }}-$ & & & $\%$ \\
\hline & $0-20$ & 30,7 & 4,9 & 37,3 & 2,6 & 32,8 & 9.0 & 44.3 & 44.4 & 88,7 & 50,2 \\
\hline \multirow[t]{3}{*}{ Pousio } & $20-40$ & 24,5 & 5,0 & 22,5 & 1,9 & 28,8 & 9,2 & 37.8 & 39.8 & 77,7 & 51,3 \\
\hline & $\begin{array}{r}40-60 \\
-\end{array}$ & $17,0$. & 5,2 & 16,0 & 1,1 & -21.7. & 8.2 & 32.2 & 31.0 & 63.2 & 49.0 \\
\hline & $0-20$ & 30,0 & 5,0 & 35,5 & 2,3 & 32,0 & 8,3 & 44.2 & 42.7 & 86,8 & 49,0 \\
\hline \multirow[t]{3}{*}{ Milho } & $20-40$ & 24,7 & 5,1 & 27,2 & 1,8 & 31,0 & 8.8 & 38,8 & 41.7 & 80,5 & 51.8 \\
\hline & $40-60$ & 17,2 & 5,3 & 20,5 & 1,2 & 27,7 & 9.7. & 30.2 & 38.5 & 68.7 & 55.7 \\
\hline & $0-20$ & 30,8 & 4,9 & 34,6 & 2,6 & 31,7 & 8.0 & 46.5 & 42.3 & 88.8 & 47.3 \\
\hline Aveia & $20-40$ & 23,2 & 5,1 & 25,2 & 1,7 & 30,2 & 8.7 & 39.2 & 40.3 & 79.5 & 51.0 \\
\hline \multirow[t]{2}{*}{ preta } & $40-60$ & $-15,2$ & $-5,3$ & 1722 & $-1,3$ & -25.5 & 8.5 & 30.7 & $35: 2$ & 65.8 & 53.7. \\
\hline & $0-20$ & 30,0 & 4,9 & 36,5 & 2,3 & 32,0 & 8.5 & 43.5 & 43.0 & 86.5 & 49.3 \\
\hline Crot & $20-40$ & 24,0 & 5,2 & 27,8 & 1,9 & 32,3 & 9.7 & 36.7 & 44.0 & 80.7 & 54.0 \\
\hline \multirow[t]{2}{*}{ juncea } & $40-60$ & 17,8 & 5,5 & 25,2 & 1,5 & -35.2 & 9.2 & $=26.8$ & +6.0 & 72.8 & 61.2 \\
\hline & $0-20$ & 29,0 & 4,8 & 32,5 & 2,5 & 28,7 & 7.3 & 47,7 & 38.5 & 86.2 & 44.5 \\
\hline \multirow[t]{3}{*}{ Guandu } & $20-40$ & 25,5 & 5,0 & 25,5 & 2,0 & 31,5 & 8.5 & 40.8 & 42.2 & 83.0 & 50.3 \\
\hline & $40-60$ & 17,5 & 5,3 & 17,2 & $-1,3$ & 28.3 & -7.3 & 31.2 & 37.0 & 68.2 & 53.5 \\
\hline & $0-20$ & 30,8 & 5,0 & 36,3 & 2,5 & 34.3 & 8.7 & 45.7 & 45.3 & 91,0 & 49.8 \\
\hline Mucuna & $20-40$ & 25,0 & 5,1 & 24,5 & 2,1 & 34.2 & 9.5 & 36.7 & 46.0 & 82.7 & 55.5 \\
\hline preta & $40-60$ & 17,3 & 5,4 & 16,8 & 1,5 & 29.8 & 9.0 & 28.0 & 40.3 & 68.3 & 58.5 \\
\hline
\end{tabular}

O teor de matéria orgânica obtido nos très anos pode ser considerado normal na profundidade de $0-20 \mathrm{~cm}$, conforme Raij et al. (1996), para solos com textura argilosa e muito argilosa (maior que $30 \mathrm{~g} / \mathrm{dm}^{3}$ ). Apos os quatro anos do presente trabalho, o teor nos diferentes tratamentos manteve-se proximo ao inicialmente determinado e também considerado normal ( $38 \mathrm{~g} / \mathrm{dm}^{3}$ ) (tabela 5)

Nas profundidades de $20-40 \mathrm{~cm}$ e de $40-60 \mathrm{~cm}$, o teor de materia orgànica foi menor, sendo equivalente ao encontrado na camada aravel em solos de textura média. 
variando de 25 a 30 e de 18 a $25 \mathrm{~g} / \mathrm{dm}^{3}$, respectivamente. Apresentou-se também normal em todas as profundidades, tratamentos e anos, de acordo com Malavolta (1995).

O poder da matéria orgânica como condicionadora do solo é de relevante importância para o desenvolvimento do feijoeiro, especialmente em relação aos parâmetros físicos do solo, tendo em vista a distribuiçào superficial de seu sistema radicular, o seu ciclo curto e a alta dependência de suas plantas às condiçōes ambientais. Ainda, a conservação da matéria orgânica é extremamente importante para a manutenção ou elevação do nível de fertilidade do solo (Bulisani et al., 1987).

Em todos os anos e em todos os tratamentos houve um pequeno decréscimo no teor de matéria orgânica em profundidade (tabelas 6.7 e 8). Essa mesma tendência foi observada ano a ano em cada tratamento e profundidade. sendo verificado um decréscimo mais acentuado na profundidade de $40-60 \mathrm{~cm}$. sobretudo em 1995 , concordando com observações de Castro (1995) e De Maria \& Castro (1993). Diante disso, pode-se afirmar que não houve produção de um volume suficiente de residuos para se ter a compensação das perdas ocorridas.

Os valores obtidos a $0-20 \mathrm{~cm}$ foram idènticos ou superiores a $30 \mathrm{~g} / \mathrm{dm}^{3}$ (tabelas 6, 7 e 8). Em estudos realizados em outras condições, mas também em um latossolo roxo, sob preparo convencional, Castro (1995) obteve valores superiores. Arf et al. (1996) relataram valores inferiores (entre 23.0 e $25.7 \mathrm{~g} \mathrm{dm}^{3}$ ). em um latossolo vermelho-escuro, textura argilosa, cultivado com feijoeiro irrigado em rotação con milho, mucuna preta e lablabe contínuos e milho - mucuna preta e milho - lablabe.

Em geral, esperam-se maiores teores de materia orgànica nas camadas superficiais em solos com menor mobilização mecànica como no plantio direto, em relação aos demais sistemas de preparo do solo (Eltz et al., 1989; Muzilli. 1983). mas isso pode depender de vários fatores, tais como: tipo de solo, clima e quantidade de fitomassa produzida pelas culturas (Castro, 1995). Os dados obtidos no presente trabalho estão de acordo com as constatações de Castro et al. (1987b), em um latossolo de textura média, sob preparo convencional.

Em média, tanto nos tratamento em pousio quanto naqueles com a presença de leguminosas e de gramineas, antecedendo o feijoeiro, obteve-se teor 
semelhante de matéria orgânica. Alves (1992) também não observou diferenças no teor de matéria orgânica, com a utilização de diversas coberturas vegetais de inverno, porém em plantio direto. Em feijoeiro têm sido observados efeitos muito positivos no rendimento de grãos, em função da adição de adubos orgànicos, de fitomassa incorporada ou não ao solo, ou também, da rotação de culturas com conservação ou incorporação de restos vegetais. Isso se verifica particularmente, quando se faz a semeadura do feijoeiro logo após a incorporação de fitomassa notadamente de leguminosas (Bulisani et al., 1987).

Em algumas situações, a inclusão de gramineas em um sistema de produção pode ser fundamental à manutenção de altos niveis de matéria orgànica no solo, conforme apresentado por Castro (1995). Na profundidade de $0-20 \mathrm{~cm}$ do presente trabalho entretanto, o teor de matéria orgânica foi maior no tratamento com mucuna preta, seguido por aveia preta e ou pousio (tabelas 6, 7 e 8).

A vegetação espontânea observada ao longo dos anos no tratamento com pousio foi composta principalmente por diferentes populaçōes de plantas de milho (ressemeadura natural da cultura anterior), picão branco (Galinsoga parviflora), picão preto (Bidens pilosa), beldroega (Portulacca oleracea), carrapicho-de-cameiro (Acanthospermun hispidum), capim-colchão (Digitaria sanguinalis) e tiririca (C.yerus rotundus). Cabe destacar que algumas destas, particularmente as duas ultimas apresentam uma nítida superioridade fisiológica, sendo consideradas plantas fotossinteticamente eficientes. Essa fitomassa diversificada, quando incorporada pode ter contribuido para a manutenção de um teor normal de matéria orgânica na camada superficial do solo.

Ainda, na profundidade de $0-20 \mathrm{~cm}$, o teor de materia orgànica relatado no tratamento com aveia preta foi sempre ligeiramente superior ao do tratamento com crotalária juncea (tabelas 6 e 7 e 8), confirmando os resultados tambem observados nessa camada arável por De Maria \& Castro (1993).

Conforme critérios adotados em Raij et al. (1996), para a camada aravel, o valor de $\mathrm{pH}$ para todas as profundidades e tratamentos em 1993 revelou uma acidez média ( $\mathrm{pH}$ entre 5,1 e 5,5), que foi a mesma observada antes do inicio da experimentação (tabela 5). Esse valor se situou no limite de acidez alta na profundidade de $0-20 \mathrm{~cm}$, 
quando a cultura da aveia preta antecedeu a do feijoeiro(tabela 6). Em 1994 (tabela 7) e em 1995 (tabela 8), os valores de $\mathrm{pH}$ a $0-20 \mathrm{~cm}$ estiveram no limite da categoria alta de acidez e média nas demais profundidades, para todos os tratamentos. à exceção do tratamento com milho, em que o índice se manteve médio nos três anos de estudo. Essa redução nos valores de $\mathrm{pH}$ certamente deveu-se à perda do efeito residual do calcário. aplicado antes do início do experimento.

Os valores de $\mathrm{pH}$ observados em todos os anos na profundidade de $0-20$ $\mathrm{cm}$ (tabela 6 e 7 e 8 ) não foram considerados adequados, segundo Malavolta (1995), mas o foram nas demais profundidades. Em geral, a faixa adequada de $\mathrm{pH}$ do solo para a cultura do feijoeiro é entre 5,5 e 6,5, com uma saturaçào por bases correspondente em torno de 70\% (Oliveira et al., 1996; Stone \& Sartorato, 1994). No Estado de São Paulo. com poucas exceções, não se obtiveram respostas positivas à utilização de calagem no feijoeiro quando o valor de $\mathrm{pH}$ foi superior a 5,5 (Feitosa et al. 1980; Mascarenhas et al., 1969 e Miyasaka et al, 1966a,b,c).

Segundo Raij et al. (1996), os parâmetros relacionados à acidez dos solos. $\mathrm{pH}$ em $\mathrm{CaCl}_{2}$ e saturação por bases $(\mathrm{V} \%$ ) são direta e estreitamente correlacionados entre si, para amostras coletadas da camada arável. Independente do tratamento, observou-se uma tendência para diminuição da acidez em profundidade, com conseqüente aumento nos valores de saturação por bases (tabelas 6, 7 e 8), confirmando a observaçào anterior Castro (1995) porém, verificou o contrário em seus trabalhos em um latossolo roxo. sob plantio convencional.

No primeiro ciclo de rotações, em 1993 e, de acordo com criterios de Raij et al. (1996) para a camada arável, o índice de saturação por bases não foi adequado para os tratamentos pousio e aveia preta, sendo observados valores baixos para esses tratamentos nas profundidades de $0-20 \mathrm{~cm}$. Também o foram a $20-40 \mathrm{~cm}$ e a $40-60 \mathrm{~cm}$ para a crotalária júncea. Nessas profundidades e para os demais tratamentos esse indice foi médio (tabela 6 ).

Em 1994 predominaram valores baixos de $\mathrm{V} \%$ em todas as profundidades para o tratamento com pousio; a 0-20 cm para os tratamentos com milho e mucuna preta e a $0-20 \mathrm{~cm}$ e a $20-40 \mathrm{~cm}$ para os tratamentos com aveia preta e guandu. Somente para o 
tratamento com a mucuna preta é que os valores foram considerados médios em todas as profundidades (tabela 7). No último ciclo de rotações, em 1995. os valores de V\% foram baixos para todos os tratamentos a $0-20 \mathrm{~cm}$ e médios a $20-40$ e $40-60 \mathrm{~cm}$. A exceção do pousio, os valores foram crescentes em profundidade, sendo superiores a $58,0 \%$ para mucuna preta e crotalária a 40-60 cm (tabela 8 ).

Por sua vez, de acordo com os criterios de Malavolta (1995) para o feijoeiro, os valores de V\% na camada de $0-20 \mathrm{~cm}$ foram considerados adequados, embora muito próximos do limite inferior da faixa mas apenas nos tratamentos com milho, crotalária juncea e mucuna preta, tanto em 1993 quanto em 1994. Em 1995 esse patamar não foi atingido em nenhum tratamento nessa mesma camada. Em relação às demais profundidades, entretanto, os valores de $\mathrm{V} \%$ foram adequados. independente do tratamento e do ano (tabelas 6,7 e 8).

Como os latossolos, em geral, apresentam boa drenagem e predominància de baixa capacidade de troca de cátions (CTC), esperava-se que não ocorresse acúmulo de bases trocáveis nas camadas superficiais, conforme mencionado em Castro (1995). Os valores tanto de soma de bases (S) quanto de CTC, entretanto, foram maiores na camada superficial de $0-20 \mathrm{~cm}$, havendo uma diminuição em profundidade. sobretudo dos valores de CTC na camada de 40 a $60 \mathrm{~cm}$ (tabelas 6,7 e 8 )

$\mathrm{O}$ maior acúmulo de matéria orgànica na camada superior de $0-20 \mathrm{~cm}$ (tabelas 6, 7 e 8), aliado aos residuos da adubação qumica. pariculamente de fertilizantes nitrogenados nas camadas superficiais. contribuiu para uma maior acidificação em relação às demais camadas, conforme obsenado por Oliveira (1996) e por Shear \& Moschler (1969). Ainda, nos tratamentos em que as leguminosas antecederam o feijoeiro, os valores de $\mathrm{pH}$ e de $\mathrm{V}^{\circ} \mathrm{o}$. em profundidade, foram um pouco maiores do que nos tratamentos com gramineas, sendo que não se realizou adubação nitrogenada em cobertura nas leguminosas

Essa situação foi mais freqüentemente observada em sistema de plantio direto por Castro et al. (1987b), Juo \& Lal (1979): Oliveira et al. (1990) e Shear \& Moschler (1969), em que há a manutenção prolongada de quantidades bem maiores de restos de fitomassa seca sobre a superficie do solo 
Em relação ao fósforo e, conforme os limites estabelecidos em Raij et al. (1996) para a camada arável, os valores foram considerados, em sua maioria, adequados e médios para todos os tratamentos e profundidades em 1993, respectivamente (entre 16 e $40 \mathrm{mg} / \mathrm{dm}^{3}$ ); altos para os tratamentos com milho e crotalária juncea a $0-20 \mathrm{~cm}$ e baixos nos tratamentos com crotalária juncea e mucuna preta a $40-60 \mathrm{~cm}$ (tabela 6 ).

Em 1994 os teores foram considerados médios em todos os tratamentos e profundidades, à exceção do tratamento com crotalária juncea, em que os valores foram altos, médios e baixos, respectivamente nas camadas de $0-20 \mathrm{~cm}, 20-40 \mathrm{~cm}$ e $40-60 \mathrm{~cm}$. Em 1995 os teores foram médios para todos os tratamentos e profundidades (tabela 7).

$\mathrm{Na}$ adubação realizada nos três anos do presente trabalho, a dose de $\mathrm{P}_{2} \mathrm{O}_{5}$ aplicada foi até superior ao recomendado por Ambrosano et al. (1996). tanto para feijoeiro de verão (safras "das águas" e "da seca") quanto de inverno irrigado. tendo em vista um determinado nível de produtividade esperado.

Conforme os critérios de Malavolta (1995) e ainda em valores compilados por Rosolem (1996), todos os teores de fósforo observados (tabelas 6. 7 e 8). independente do tratamento, profundidade e ano, tambem foram adequados. Em pesquisas realizadas por Castro (1995), em um latossolo roxo. sob preparo convencional. os resultados foram superiores, sobretudo nas profundidades de $20-40 \mathrm{~cm}$ e $40-60 \mathrm{~cm}$.

Segundo Kornelius et al. (1976). com um teor de cerca de $35 \mathrm{ppm}$ ( 35 $\left.\mathrm{mg} / \mathrm{dm}^{3}\right)$ de fósforo no solo, pode-se atingir $80 \%$ da produtividade máxima do feijoeiro Embora a exigência do feijoeiro por esse nutriente seja por quantidades relativamente pequenas, obtém-se respostas em maior numero e mais freqüentemente à aplicação desse nutriente na cultura do feijoeiro (Rosolem, 1987).

Os teores de fósforo foram decrescentes em profundidade. tanto para tratamentos quanto para anos, sendo bem maiores na camada superficial (tabelas 6, 7 e 8), seguindo uma tendência observada em latossolo roxo por Castro et al. (1987b) e por De Maria \& Castro (1993), após três anos de cultivo em latossolo roxo argiloso

Também, de modo geral, foram decrescentes de ano para ano. em todos os tratamentos, à exceção do pousio na camada de $0-20 \mathrm{~cm}$ (tabelas 6.7 e 8 ). Esses 
resultados, porém, são discordantes daqueles observados por Oliveira (1996), em estudos de sucessão de culturas (soja, trigo e milho) com adubaçào verde (crotalária juncea).

Esse maior acúmulo de fósforo nas camadas superficiais, em que o nutriente é colocado por meio de adubadoras, deve-se, em parte, à menor mobilidade do elemento no solo, à sua reposição anual na forma de fertilizante quimico e também, à adição apenas superficial dos produtos resultantes da mineralização da matéria orgânica, conforme observado por Castro \& De Maria (1993) e por Oliveira (1996).

No caso do tratamento com pousio, em que os teores de fosforo foram um pouco maiores na camada superficial $(0-20 \mathrm{~cm})$ e crescentes a cada ano (tabelas 6, 7 e 8), pode-se fazer uma analogia com a situação observada em esquema de plantio direto ou reduzido por Centurion et al. (1985); De Maria \& Castro (1993); Eltz et al. (1989); Muzilli (1983) e Shear \& Mochler (1969). Diante da menor mobilização do solo nesse tratamento em relação aos demais, as chances de adsorçào especifica do fosforo residual, especialmente pelo contacto com os sesquióxidos de ferro e de aluminio sào reduzidas e então o elemento estaria mais disponivel.

Os teores médios de potássio estavam adequados nos très anos, situandose na faixa considerada média nas profundidades de $0-20 \mathrm{~cm}$ e $20-40 \mathrm{~cm}$ e baixa a $40-60$ $\mathrm{cm}$ (tabelas 6, 7 e 8), conforme critérios de Malavolta (1995) e Raij et al. (1996), para a camada arável. Esses teores de potássio foram decrescentes em profundidade e de ano para ano, não sendo muito diferentes na comparação dos tratamentos (tabelas 6, 7 e 8) Mostraram-se ainda, superiores aos observados por Castro (1995) em latossolo roxo, sob preparo convencional.

$\mathrm{O}$ acúmulo de potássio em solos de baixa CTC. como os latossolos, é dependente do regime de chuvas e da sua drenagem. A lixiviaçào desse elemento no perfil do solo ocorre mediante a existência de condições favoraveis para esta drenagem, conforme destacado por De Maria \& Castro (1993).

Como os niveis de potássio no presente estudo. entretanto, foram considerados médios e ou adequados, ao longo dos anos. havendo acumulo sobretudo na camada de $0-20 \mathrm{~cm}$, verifica-se que a quantidade do nutriente adicionada anualmente por 
meio da adubação química foi adequada, estando de acordo com a recomendação de Ambrosano et al. (1996) para a cultura do feijoeiro no Estado de São Paulo.

Nos três anos, os teores de cálcio e também de magnésio foram sempre altos e adequados, conforme critérios de Malavolta (1995) e Raij et al. (1996), para a camada arável, e também em todas a profundidades e tratamentos. Com a aplicação de 2,0 toneladas de calcário dolomítico/hectare, antes da instalação do experimento, houve garantia de suprimento desses nutrientes em função das necessidades do feijoeiro (tabelas $6,7$ e 8$)$.

Cabe ressaltar que os níveis observados de magnésio nos très últimos anos da experimentação (tabelas 6,7 e 8) foram bem superiores ao estabelecido por Ambrosano et al. (1996). Segundo os autores, a utilizaçào de calagem em feijoeiro também objetiva elevar o teor de magnésio a um minimo de $5 \mathrm{mmol}_{\mathrm{c}} / \mathrm{dm}^{3}$.

Ao longo dos anos, observou-se uma pequena reduçào nos teores de cálcio na camada arável $(0-20 \mathrm{~cm}$ ) (tabelas 6, 7 e 8), fato esse justificado pela nào adição de calcário à área experimental, com continuada remoção desse elemento pelos grãos das culturas. Como o solo em questão apresenta boas condições naturais de drenagem, observou-se, também, uma correção em profundidade, uma vez que os niveis desses elementos nas camadas menos superficiais foram adequados (tabelas 6.7 e 8). Isso se refletiu no aumento dos valores de $\mathrm{pH}$ e de $\mathrm{V} \%$ em profundidade.

Resultados semelhantes foram obtidos por Muzilli (1981). em latossolo roxo no Paraná e por Centurion et al. (1985), em latossolo vermelho escuro argiloso.

A relação cálcio-magnésio considerada ideal para a cultura do feijoeiro é 4:1 (Oliveira et al., 1996). Neste trabalho, esta esteve proxima desse valor, notadamente nos tratamentos com leguminosas nos três anos de avaliação (tabelas 6.7 e 8).

De maneira geral, pode-se dizer que as caracteristicas quimicas do solo no presente estudo não foram impeditivas ao cultivo do feịoeiro (tabelas 6,7 e 8 ) Entretanto, devido à acidez média observada na camada aravel $(0-20 \mathrm{~cm})$ e. independente do tratamento utilizado, não houve condições para a expressão maxima do potencial produtivo desta leguminosa. 


\subsection{Densidade do solo e resistência à penetração (RP)}

Os valores obtidos na determinação da densidade do solo. realizada ao final do experimento, em janeiro de 1996, constam da tabela 9. Não se observaram diferenças significativas entre os tratamentos em cada profundidade. entre as médias de profundidades e nem na interação tratamento $x$ profundidade

Esses resultados assemelham-se aos obtidos por Castro (1991). em um latossolo roxo, sob preparo convencional, até $40 \mathrm{~cm}$. Em estudos de manejo de culturas em rotação, também em latossolo roxo e sob preparo convencional. Castro (1995) relatou valores de $1,30 \mathrm{~g} / \mathrm{cm}^{3}$ e $1,32 \mathrm{~g} / \mathrm{cm}^{3}$, na media das profundidades de $0-20 \mathrm{~cm}$ e 20 $45 \mathrm{~cm}$, respectivamente.

À exceção do observado nos tratamentos com guandu e milho e. embora não tenha sido significativo, houve um aumento dos valores de densidade do solo da profundidade de $0-20 \mathrm{~cm}$ para a de $20-40 \mathrm{~cm}$, notadamente nos tratamentos com pousio e aveia preta $\mathrm{e}$, em menor intensidade, com mucuna preta. $\mathrm{O}$ maior valor, que foi da ordem de $1,42 \mathrm{~g} / \mathrm{cm}^{3}$ e obtido no tratamento com aveia preta a $20-40 \mathrm{~cm}$ (tabela 9), assemelhou-se ao citado por Castro (1995), a $20 \mathrm{~cm}$. em um latossolo roxo. sob preparo convencional

Também em um latossolo roxo na regiào de Assis. SP. arribuiram-se as reduções nas produções das culturas à presença constatada de uma camada compactada a $20 \mathrm{~cm}$ de profundidade com densidade variável entre $1.20 \mathrm{~g} \mathrm{~cm}^{*} \mathrm{e} 1.45 \mathrm{~g} / \mathrm{cm}^{3}$. em apenas $50 \mathrm{~cm}$ de distância horizontal (Nogueira \& Manfredini. 1983)

Essa tendência para aumento da densidade do solo na transiçào da camada de $0-20 \mathrm{~cm}$ para $20-40 \mathrm{~cm}$ (tabela 9) caracteriza uma situação de compactação subsuperficial, abaixo da camada mobilizada, ocasionada pela açào de implementos agricola (arado e grade) e pelo trânsito de máquinas. que e denominada "pe-de-arado". Segundo Camargo (1983), "pode-se dizer, com certa restriçào. que a densidade global é a medida quantitativa mais direta da compactação". 
Tabela 9: Densidade de um latossolo roxo, em duas profundidades, após cultivo do feijoeiro, cultivar IAC-Carioca, em rotação com milho/culturas graniferas e adubos verdes. Ribeirão Preto, SP, janeiro de 1996.

\begin{tabular}{|c|c|c|c|c|c|c|c|}
\hline \multirow{2}{*}{$\begin{array}{l}\text { Profun- } \\
\text { didade }\end{array}$} & \multicolumn{6}{|c|}{ Cultura anterior ao feijoeiro } & \multirow[b]{2}{*}{ Média } \\
\hline & Pousio & Milho & $\begin{array}{l}\text { Aveia } \\
\text { preta }\end{array}$ & $\begin{array}{c}\text { Crotalaria } \\
\text { juncea }\end{array}$ & Guandu & $\begin{array}{c}\text { Mucuna } \\
\text { preta }\end{array}$ & \\
\hline$--\mathrm{cm}-$ & & & & $-\mathrm{g} / \mathrm{cm}^{3}$ & & & \\
\hline $0-20$ & $1,28 \mathrm{~A}$ & $1,40 \mathrm{~A}$ & $1,30 \mathrm{~A}$ & $1,31 \mathrm{~A}$ & $1,34 \mathrm{~A}$ & $1,31 \mathrm{~A}$ & $1,33 \mathrm{a}$ \\
\hline $20-40$ & $1,39 \mathrm{~A}$ & $1,40 \mathrm{~A}$ & $1,42 \mathrm{~A}$ & $1,34 \mathrm{~A}$ & $1,31 \mathrm{~A}$ & $1,39 \mathrm{~A}$ & $1.37 \mathrm{a}$ \\
\hline
\end{tabular}

$\mathrm{CV} \%$ para profundidade $=5,2 \% ; \mathrm{CV} \%$ para tratamento $=9,9 \%$.

Médias seguidas pelas mesmas letras minúsculas nas colunas e maiusculas nas linhas não diferem entre si pelo teste de Duncan a $5 \%$.

A compactação do solo constitui um problema serio em àreas irrigadas, particularmente naqueles solos onde se cultiva mais de uma cultura por ano (Pires et al., 1991). Ela pode reduzir os fluxos de ar e de água, pela redução dos espaços vazios, bem como diminuir a resistência mecânica dos solos, sendo prejudicial ao crescimento e desenvolvimento do sistema radicular das plantas.

Segundo Greacen (1986), em geral a taxa de elongação radicular é inversamente proporcional ao impedimento mecânico em um solo. Além disso. o intensivo uso agrícola dos latossolos roxos pode até mesmo destruir a estrutura original dos seus horizontes superficiais (Oliveira \& Moniz, 1975).

Os resultados da avaliação da compactação do solo, realizada com penetrômetro de impacto, em 1993, 1994 e 1995, em diferentes profundidades e tratamentos, encontram-se, respectivamente, nas figuras 1, 2 e 3.

Os valores de resistência à penetraçâo (RP) representam a combinaçào das características fisicas do solo, particularmente da sua densidade e da sua umidade (Mirreh \& Ketcheson, 1972). Analisando-se os resultados de todos os tratamentos em todos os anos, verifica-se a presença de uma camada mais compactada em todas as determinaçòes no perfil do solo. Há um aumento crescente dos valores de RP em profundidade ate uma determinada camada, com posterior redução gradual (figuras 1 a 3 ). 
Resistência à penetração. $\mathrm{MPa}$

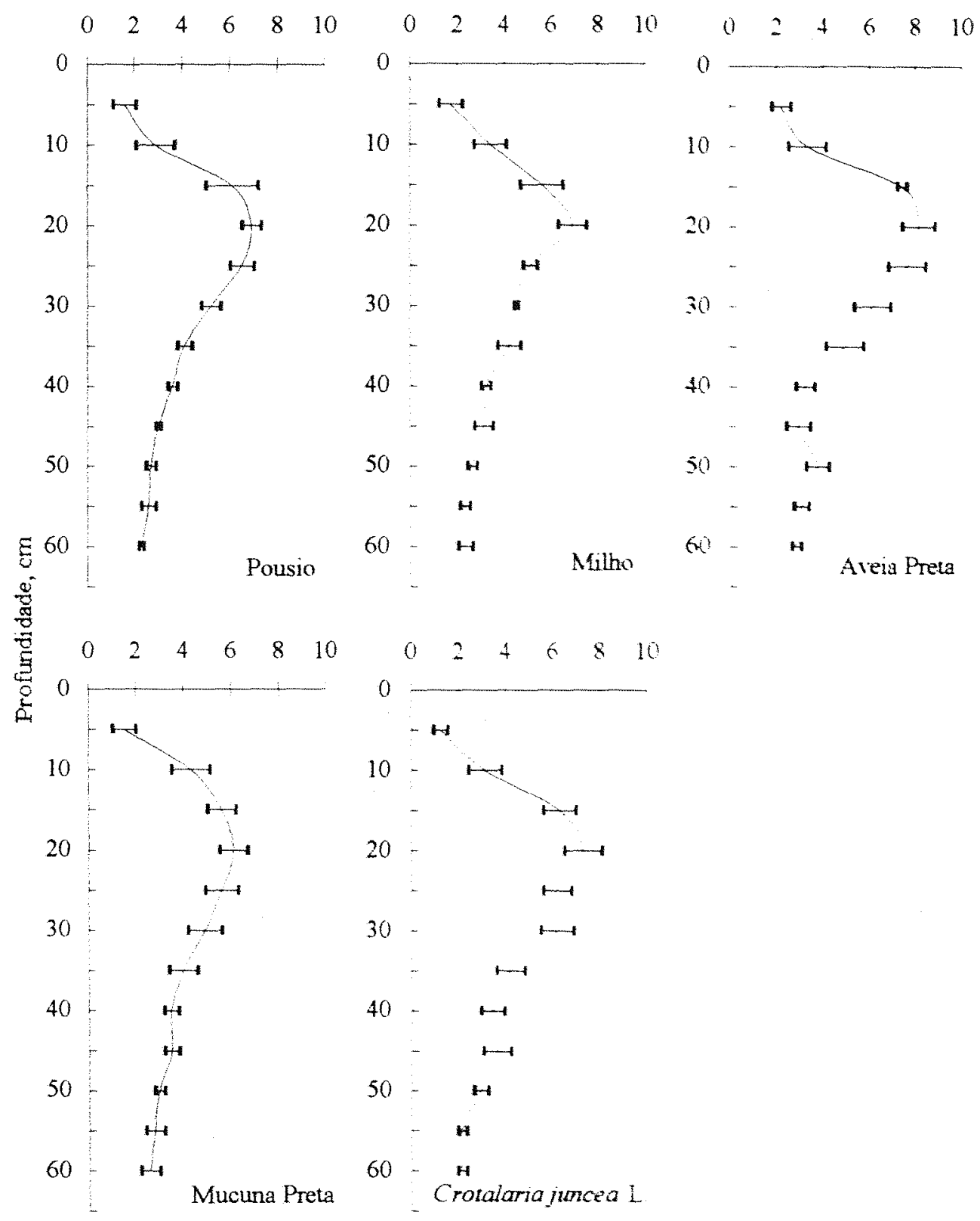

Figura 1: Valores médios de resistència a penetraçào $(R P)=$ emo padrào da media (epm), em MPa, com pentrômetro de impacto modelo LAAPLANALSUCAR. em diferentes profundidades, em latossolo roxo culturado com feijiciro e apos rotação com culturas graniferas e adubos verdes. Ribeurà Prero. SP. 1993. 
Resistência à penetraçào. $\mathrm{MPa}$

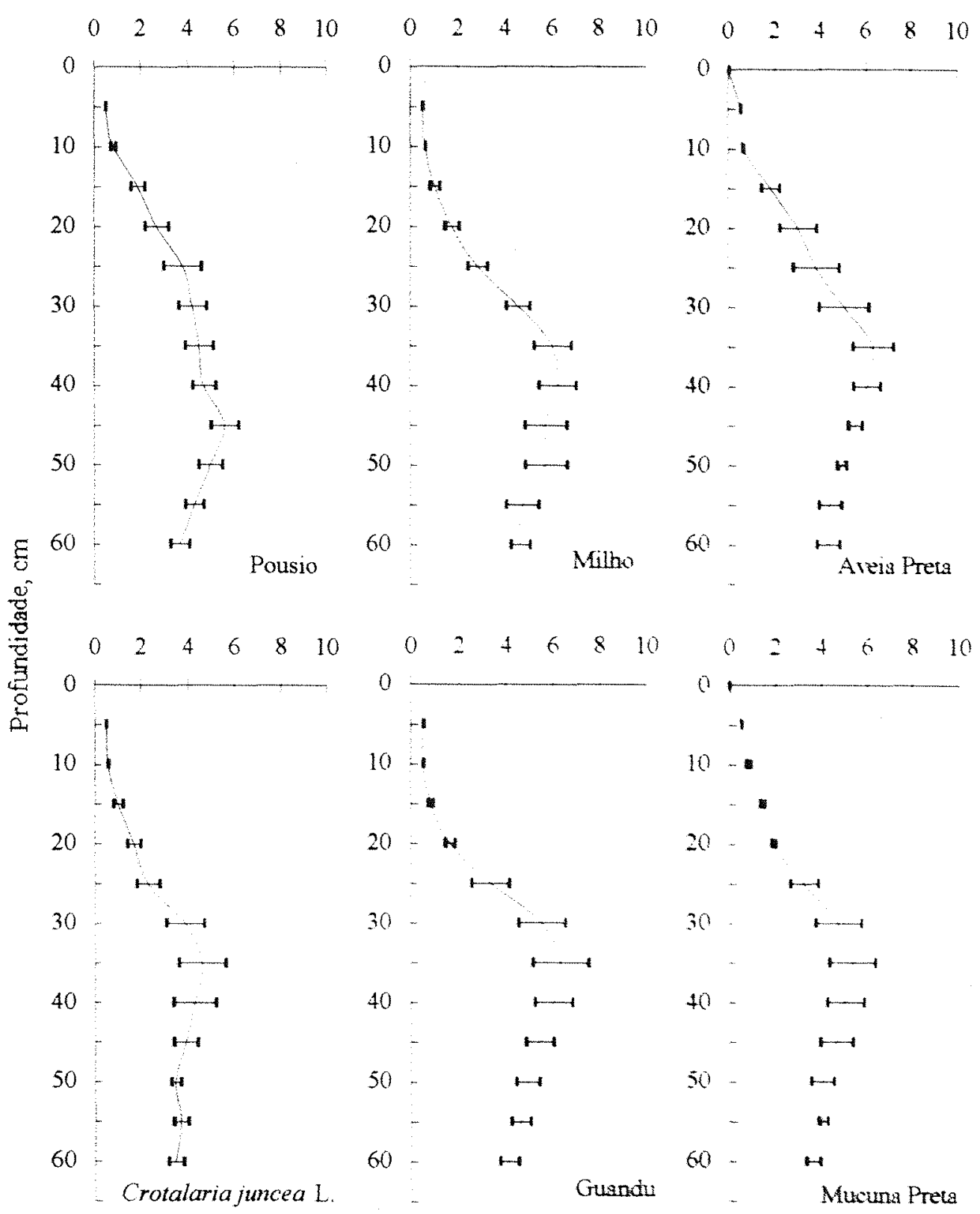

Figura 2: Valores médios de resistência à penetraçăo $(R P)=$ erro padrào da media (epm), em MPa, com pentrómetro de impacto modelo LAAPLANALSUCAR em diferentes profundidades, em latossolo roxo cultivdo con feicoeiro e após rotação com culturas graniferas e adubos verdes Rikeirão Preto. SP. 1994. 
Resistência a penetraçào. MPa

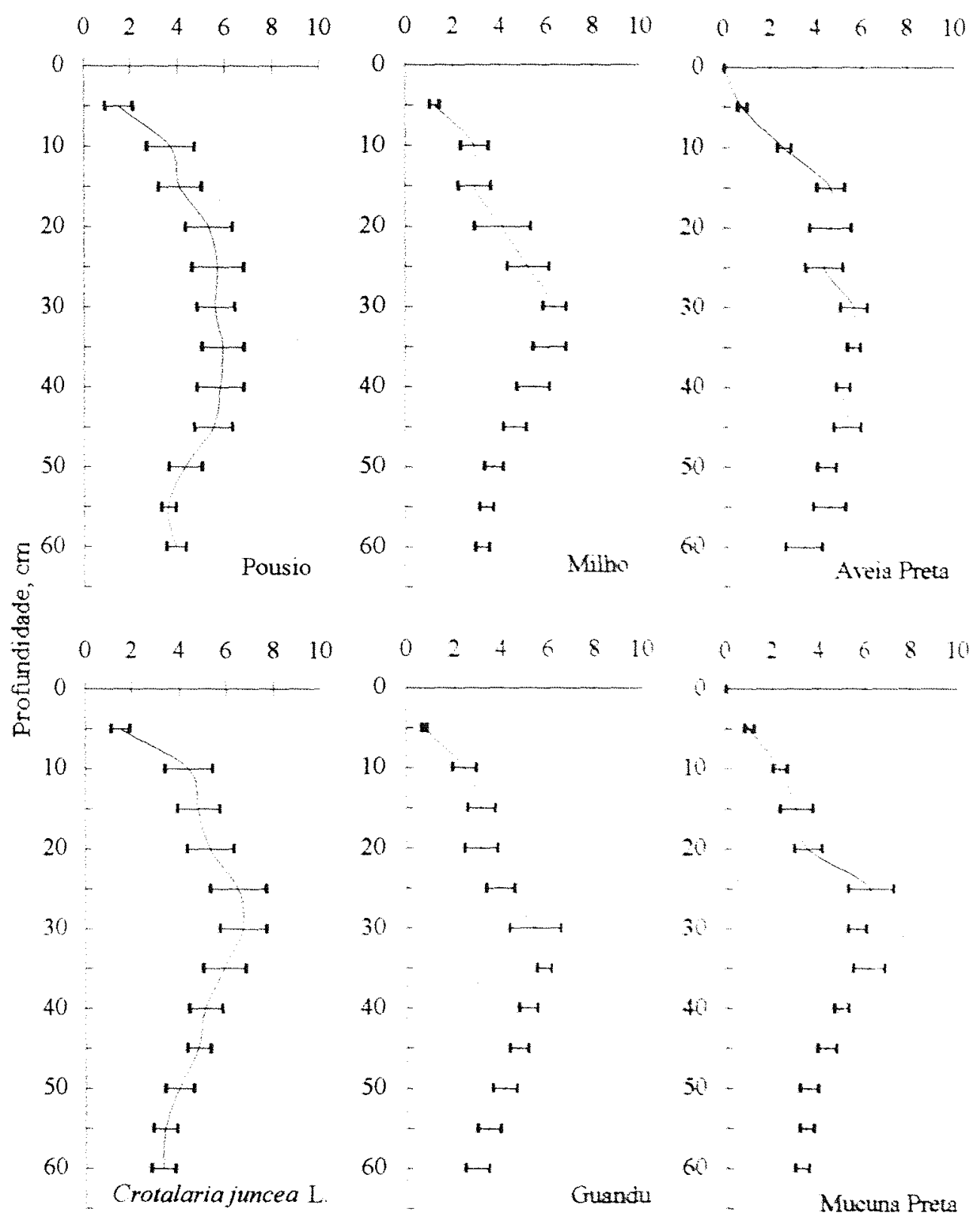

Figura 3: Valores médios de resistência à penetraçào $(R P)=$ ero padrão da media (epm), em MPa, com pentrômetro de impaco modelo LAA PLANALSUCAR. em diferentes profundidades, em latossolo roxo cultrvado om feifoeion a apos rotaçâo com culturas graniferas e adubos verdes. Ribeiráo Preto. SP. 1995 
Em 1993, os maiores valores de RP, independente do tratamento, localizaram-se na camada de 15 a $30 \mathrm{~cm}$, sendo superiores no tratamento com aveia preta (figura 1). Como efeito prático da rotação com diferentes culturas, essa camada com maiores valores de RP localizou-se mais abaixo nos anos seguintes. Em 1994, esta situou-se na profundidade de $30-40 \mathrm{~cm}$ e novamente os valores no tratamento com aveia preta foram um pouco superiores aos demais (figura 2). No último ano da experimentação, em 1995, os valores observados nas camadas superficiais até cerca de 30 $\mathrm{cm}$ de profundidade foram um pouco maiores do que em 1994. particularmente no tratamento com crotalária juncea. A camada mais compactada situou-se na profundidade de 25 a $35 \mathrm{~cm}$, e os valores foram um pouco maiores no tratamento com crotalária juncea, particularmente a $25-30 \mathrm{~cm}$ (figura 3 )

Pires et al. (1991) também observaram maiores valores de RP, em medições com penetrômetro de impacto, na camada de $30-40 \mathrm{~cm}$ do perfil de um solo cultivado com feijoeiro irrigado por pivô central, em podzolico vermelho-amarelo latossólico eutrófico, textura arenosa/média, sob preparo convencional. em Votuporanga. SP. Castro (1995) relatou os maiores valores de RP, medidos com penetròmetro de bolso, na camada de 20 a $35 \mathrm{~cm}$, em latossolo roxo, sob preparo convencional. em seus estudos envolvendo rotação de culturas, em Campinas, SP. O maior valor de RP foi observado a $20 \mathrm{~cm}$, sendo da ordem de $4,3 \mathrm{MPa}$.

Como o solo do presente estudo apresenta uma composiçào granulométrica uniforme nos horizontes superficiais $(0-20 \mathrm{~cm}$ e $20-40 \mathrm{~cm}$ ) (tabela 2). as diferenças observadas em relação à RP ao longo do perfil do solo (figuras 1.2 e 3 ) podem ser atribuídas à compactação do solo e não a um possivel gradiente textural.

Ainda, conforme os resultados apresentados nas figuras 1 a 3 , observa-se um gradiente acentuado de RP, da profundidade inicial de $0-5 \mathrm{~cm}$ (menor valor em todos os tratamentos e anos) para a camada onde se obteve o maior valor de RP em cada tratamento e ano. Assim, em relação à primeira camada do solo, os valores aumentaram cerca de 3,7 a 6,1 vezes em 1993; de 9,2 a 12,6 vezes em 1994 e de 3.9 a 8.3 vezes em 1995 (figuras 1 a 3). Essa relação foi bem superior à observada por Castro (1995). em latossolo roxo, em que houve um aumento do valor de RP de 3.5 vezes na camada de 0 - 
$20 \mathrm{~cm}$ (maior valor) em relação à camada superficial de $0-5 \mathrm{~cm}$. sob preparo convencional. Esse gradiente de resistência assume importância quando se considera o desenvolvimento radicular de uma cultura (Taylor, 1974). Em seus estudos em solo argiloso, De Maria et al. (1993) mostraram uma elevada correlaçào entre gradiente de resistência e crescimento radicular de plantas de soja. Os resultados das avaliaçôes com o uso de penetrômetro, portanto, devem ser comparativos e não uma medida absoluta das forças exercidas sobre as raizes em sua penetração no solo (Russell \& Goss. 1974).

\subsection{Velocidade de infiltração básica - VIB}

Os valores de velocidade de infiltração basica (VTB). medida com infiltrômetro de nivel constante, estão relacionados na tabela $10 \mathrm{Em}$ relação ao pousio, destacaram-se significativamente $\mathrm{e}$, em ordem decrescente. aqueles obtidos nos tratamentos em que o feijoeiro foi antecedido sobretudo pela mucuna preta e crotalaria juncea e ainda, pelo milho. Esses valores foram muito superiores ao observado por Silva (1980), em área cultivada convencionalmente em latossolo roxo $(2.0 \mathrm{~mm} / \mathrm{h})$.

O menor valor de VIB foi obtido no tratamento com a aveia preta (11,0 $\mathrm{mm} / \mathrm{h}$ ), que só não diferiu significativamente do pousio. sendo cerca de $71.7^{\circ}$ o inferior ao maior relatado (tratamento com mucuna preta $=18.9 \mathrm{~mm} / \mathrm{h})($ tabela 10$)$.

Tabela 10: Infiltração básica (VIB) em um latossolo roxo. apos cultivo com feijoeiro. cultivar IAC-Carioca, em rotação com milho culturas graniferas e adubos verdes. Ribeirão Preto, São Paulo, janeiro de 1996

\begin{tabular}{lc}
\hline \multicolumn{1}{c}{ Cultura anterior ao feijoeiro } & VTB \\
\hline & $-\mathbf{m m} / \mathbf{h}-$ \\
Pousio & $13.6 \mathrm{~cd}$ \\
Milho & $16.6 \mathrm{ab}$ \\
Aveia preta & $11.0 \mathrm{~d}$ \\
Crotalaria juncea L. & $18.0 \mathrm{ab}$ \\
Guandu & $15.3 \mathrm{bc}$ \\
Mucuna preta & $18.9 \mathrm{a}$ \\
\hline Média & 15.6 \\
\hline CV (\%) & 11.0 \\
\hline
\end{tabular}

Médias seguidas pelas mesmas letras minúsculas nas colunas nào diferem entre si pelo teste de Duncan a $5 \%$. 
Em seus estudos em um latossolo roxo, Dalla Rosa (1981) determinou uma infiltração básica, com infiltrômetro, de $48 \mathrm{~mm} / \mathrm{h}, 8 \mathrm{~mm} / \mathrm{h}$ e $192 \mathrm{~mm} / \mathrm{h}$, respectivamente, na superficie, na camada compactada situada a $25-30 \mathrm{~cm}$ e em profundidades maiores que $30 \mathrm{~cm}$, em que praticamente não se observaram efeitos do manejo no solo.

Em determinações com chuva simulada, Arzeno (1990) e Roth \& Meyer (1983) obtiveram, respectivamente, uma infiltração básica de $29 \mathrm{~mm} / \mathrm{h}$ e $28 \mathrm{~mm} / \mathrm{h}$, em um latossolo roxo, sob preparo convencional. Castro (1995), por sua vez observou valores de infiltração, medida com permeâmetro de Guelph, da ordem de $11.88 \mathrm{~mm} / \mathrm{h}$ e 46,15 $\mathrm{mm} / \mathrm{h}$, respectivamente, na superficie e na profundidade de $20 \mathrm{~cm}$. também em um latossolo roxo, sob preparo convencional.

A variabilidade dos resultados anteriormente relatados pode ser devida tanto às condições locais quanto ao método de avaliação utilizado. No Paraná. Sidiras \& Roth (1984) encontraram essas relações diferenciadas entre avaliações de infiltração com chuva simulada e infiltrômetro. Castro et al. (1987a) e Vieira \& Muzilli (1984) também observaram a ocorrência dessas diferenças.

No presente trabalho, os menores valores de VIB foram obtidos no tratamento com restos vegetais incorporados de aveia preta (tabela 10). Contrariamente, Sidiras \& Roth (1987) observaram as maiores taxas de infiltraçào de agua no tratamento com restos culturais de aveia preta em relação a outras especies de gramineas e de leguminosas. Esse efeito mais positivo entretanto, deve-se ao fato desses restos não terem sido incorporados. No presente trabalho, alem da incorporaçào destes, a quantidade de fitomassa produzida pela aveia preta foi menor do que aquela produzida pela mucuna preta, pela crotalária júncea e pelo milho (tabela 4).

No tratamento com milho, os valores de VIB não diferiram significativamente daqueles em que as leguminosas mucuna preta e crotalária júncea antecederam o feijoeiro (tabela 10). Essa graminea em particular, geralmente apresenta valor elevado para a relação $\mathrm{C} / \mathrm{N}$, o que faz com que sejam observados efeitos benéficos dos restos de sua fitomassa, quer em cobertura ou quando incorporada. Alem disso. a 
quantidade de fitomassa produzida por esta graminea nos três anos do experimento foi superior ou assemelhou-se à produzida por essas duas leguminosas (tabela 4).

A obtenção de maiores valores de VIB nos tratamentos em que as leguminosas antecederam o feijoeiro, notadamente a mucuna preta e a crotalária juncea, está particularmente relacionada aos efeitos físicos positivos da incorporação de sua fitomassa, imediatamente antes da semeadura do feijoeiro, destacando-se, entre eles, aqueles relacionados com a melhoria da aeração. Esses efeitos já foram muito evidenciados na literatura e os resultados dos mais diversos estudos foram compilados por Bulisani et al. (1992). Inclusive, Miyasaka et al. (1966a) observaram que a incorporação de fitomassa semi-decomposta contribuiu para a manutenção de maior umidade no solo cultivado com o feijoeiro.

$O$ efeito benéfico da incorporação de grande quantidade de fitomassa não está relacionado apenas à estabilização da estrutura de um solo mas. sobretudo. ao aumento do seu volume, conforme demonstrado em avaliaçôes de densidade aparente (Joffe, 1955). Há um aumento da porosidade em favor da permeabilidade e, conseqüentemente, uma melhoria da estrutura (Bulisani et al, 1992). Ainda, as leguminosas apresentam um sistema radicular pivotante. com capacidade de crescimento em profundidade e o efeito da incorporação seja de suas raizes sẹa de sua parte aerea pode ser semelhante, conforme ressaltado por Camargo \& Herrmann (1928)

\subsection{Teor de macronutrientes nas folhas}

Os teores de macronutrientes em folhas de feijoeiro. quando as plantas se encontravam no início do estádio $R_{7}$, em 1994 e 1995. estão relacionados na tabela 11

Essa época de amostragem foi ao redor dos 55 dias de idade das plantas, durante o seu florescimento pleno e início de formação de vagens. quando. em média, verifica-se acúmulo mais intenso de nutrientes e de materia seca no fejijoeiro (Bulisani, 1994; Cobra Neto, 1967; Fageria \& Souza, 1995; Gallo \& Mryasaka. 1961: Haag et al. 1967). Muitas vezes, as variaçôes detectadas na absorção de nutrientes pelos mais diversos autores decorrem das diferenças entre os cultivares estudados e das condições agroclimáticas no local da avaliação (Oliveira \& Thung. 1988) 
Tabela 11: Teores de macronutrientes em folhas de feijoeiro, cultivar IAC-Carioca, no estádio $R_{7}$, em rotação com milho/culturas graniferas e adubos verdes. Ribeirão Preto, São Paulo, 1994 e 1995.

\begin{tabular}{|c|c|c|c|c|c|c|c|c|c|}
\hline \multirow{2}{*}{$\begin{array}{l}\text { Nutri- } \\
\text { ente }\end{array}$} & \multirow[t]{2}{*}{ Ano } & \multicolumn{6}{|c|}{ Cultura anterior ao feijoeiro } & \multirow[t]{2}{*}{ Médis } & \multirow[t]{2}{*}{$\mathrm{CV}$} \\
\hline & & Pousio & Milho & $\begin{array}{l}\text { Aveia } \\
\text { preta }\end{array}$ & $\begin{array}{c}\text { Crotaläria } \\
\text { juncea }\end{array}$ & Guandu & $\begin{array}{l}\text { Mucuna } \\
\text { preta }\end{array}$ & & \\
\hline & & \multicolumn{7}{|c|}{ - } & $-\%$ \\
\hline & 1 & 33 , & 34,1 & 34,4 & 34.6 & 35.3 & 35.2 & $34.5 \mathrm{~b}$ & - \\
\hline \multirow[t]{2}{*}{$\mathbf{N}$} & 1995 & 35,3 & 36,1 & 34,6 & 35.3 & 35.7 & 35,4 & $35 .+a$ & -- \\
\hline & Média & 34,4 A & $35,1 \mathrm{~A}$ & $34,5 \mathrm{~A}$ & $35,0 \mathrm{~A}$ & $35.5 \mathrm{~A}$ & $35,3 \mathrm{~A}$ & - & 2,5 \\
\hline & 199 & $2, \overline{1}$ & $2, \overline{3}$ & $\overline{1} . \overline{8}$ & 1.9 & 1.8 & 2.0 & $2.0 \mathrm{a}$ & - \\
\hline \multirow[t]{2}{*}{$\mathbf{P}$} & 1 & 1.4 & 1,8 & 1.6 & 1.6 & 1.5 & 1.7 & $1.6 \mathrm{~b}$ & -- \\
\hline & Média & $1,7 \mathrm{~A}$ & $2,0 \mathrm{~A}$ & $1,7 \mathrm{~A}$ & $1,8 \mathrm{~A}$ & $1.6 \mathrm{~A}$ & $1,8 \mathrm{~A}$ & & 7,9 \\
\hline & 199 & 18,2 & 21,2 & 18,6 & $\overline{21.5}$ & $20 . \overline{7}$ & 21.1 & $2.0 \mathrm{a}$ & $=$ \\
\hline \multirow[t]{2}{*}{$\mathbf{K}$} & 199 & 19.4 & 19.8 & 19.8 & 22.6 & 20.5 & 21.6 & $2.1 \mathrm{a}$ & -- \\
\hline & Média & $18,8 \mathrm{C}$ & $20,5 \mathrm{ABC}$ & $19,2 \mathrm{BC}$ & $21,9 \mathrm{~A}$ & $20,6 \mathrm{ABC}$ & $21,3 \mathrm{AB}$ & & 6.5 \\
\hline & 1994 & 17,0 & 19.4 & $\overline{18.2}$ & $\overline{19.7}$ & 19.3 & $\overline{18.2}$ & $18.6 \mathrm{~b}$ & - \\
\hline \multirow[t]{2}{*}{$\mathrm{Ca}$} & 1995 & 30,3 & 31,9 & 32.0 & 32.9 & 34.8 & 32.3 & $32.4 \mathrm{a}$ & - \\
\hline & Média & $23,7 \mathrm{~B}$ & $25,3 \mathbf{A B}$ & $24,7 \mathbf{A B}$ & $25,9 \mathrm{~A}$ & $26.5 \mathrm{~A}$ & $24,7 \mathbf{A B}$ & $=$ & 5.4 \\
\hline & 1994 & $\overline{3}, \overline{3}$ & $\overline{3}, \overline{6}$ & $\overline{3 .} \overline{1}$ & 3.4 & 3.6 & 3,3 & $3.4 \mathrm{~b}$ & - \\
\hline \multirow[t]{2}{*}{$\mathbf{M g}$} & 1995 & 5,3 & 5,9 & 5.5 & 5.3 & 5.6 & 5.6 & $5.5 \mathrm{a}$ & - \\
\hline & Média & $4,2 \mathrm{~A}$ & $4,7 \mathrm{~A}$ & $4,2 \mathrm{~A}$ & $4,3 \mathrm{~A}$ & $45 A$ & $4.4 \mathrm{~A}$ & $=$ & 55 \\
\hline \multirow{3}{*}{$\mathbf{S}$} & 1994 & $\overline{4}, \overline{3}$ & $4 . \overline{7}$ & $\overline{4} . \overline{9}$ & 4.4 & 4.1 & 5.1 & $4 . \bar{b}$ & - \\
\hline & 1995 & 6,1 & 5,8 & 6.2 & 5.9 & 5.8 & 6.8 & $6.1 \mathrm{a}$ & - \\
\hline & Média & $5,2 \mathrm{AB}$ & $5,2 \mathrm{AB}$ & $5,5 \mathrm{AB}$ & $5.1 \mathrm{~B}$ & $49 \mathrm{~B}$ & $59 \mathrm{~A}$ & - & 8.0 \\
\hline
\end{tabular}

Médias seguidas pelas mesmas letras minusculas nas colunas, para cada nutriente. e maiusculas nas linhas não diferem entre si pelo teste de Duncan a $5 \%$

No presente trabalho, à exceção do fósforo, houve um aumento dos teores de macronutrientes de 1994 para 1995. Os valores de nitrogènio observados em 1995 foram significativamente superiores aos de 1994. sendo superiores aos relatados por Arf et al (1996) e considerados adequados em ambos os anos e em todos os tratamentos, conforme Ambrosano et al. (1996); Benton Jones et al (1991): Cobra Neto et al. (1971); Gallo \& Miyasaka (1961); Haag et al. (1967); Hiroce et al. (1969); Malavolta (1969,1987); Piggot (1986); Rosolem (1987) e Wilcox \& Fageria (1976). Não se observaram diferenças significativas entre os tratamentos e tampouco efeito da interação tratamento $\mathrm{x}$ ano para os teores foliares deste nutriente. 
Em muitos dos trabalhos relacionados anteriormente, não se objetivou a determinação de níveis críticos porém, em estudos de Feitosa et al. (1980) o valor de $3,5 \%$ de nitrogênio, em amostras da $3^{\text {a }}$ folha de plantas de feijoeiro irrigado, no florescimento, correlacionou-se com produtividade elevada, ao redor de $3.100 \mathrm{~kg} / \mathrm{ha}$. Como os valores apresentados na tabela 11, sobretudo aqueles de 1995 são similares a este valor, pode-se dizer que algum possivel comprometimento da produtividade potencial do feijoeiro não se deveu a este nutriente.

No presente trabalho, a adubação quimica utilizada em todos os tratamentos foi suficiente para garantir o suprimento do nitrogènio, concordando com afirmações de Youngdahl et al. (1982). Segundo estes autores, para que o fornecimento de nitrogênio à planta não seja limitante, é necessaria a manutenção de adequada concentração desse elemento na região próxima à superficie radicular. Conforme Martin et al. (1976), tanto o nitrogênio total quanto as formas soluveis na planta se correlacionam com a quantidade fornecida de nitrogênio.

Em relação ao fósforo, não se observaram diferenças significativas entre os tratamentos nem efeito da interação tratamento $\mathrm{x}$ ano. Entretanto, os teores deste elemento foram significativamente maiores em 1994 em relaçào a 1995. sendo porém inferiores a $25 \mathrm{~g} / \mathrm{kg}$ em ambos os anos (tabela 11). São. portanto. não adequados, de acordo com Ambrosano et al. (1996); Benton Jones et al. (1991); Cobra Neto et al. (1971); Feitosa et al. (1980); Gallo \& Miyasaka (1961): Malavolta (1969. 1987); Piggot (1986); Rosolem (1987) e Wilcox \& Fageria (1976). Os valores obtidos caracterizaram uma situação de deficiência em fósforo, em ambos os anos. concordando com Hiroce et al. (1970), os quais determinaram ser necessário um teor foliar de $0,33 \%(3,3 \mathrm{~g} / \mathrm{kg})$ de fósforo em feijoeiro para se atingir uma produtividade equivalente a $80 \%$ da maxima. Em relação a 1995, entretanto, os resultados são discordantes do nivel de deficiência estabelecido por Cobra Neto et al. (1971), por serem um pouco superiores a este.

Os resultados, de modo geral, foram bem inferiores aos obtidos por exemplo, por Arf et al. (1996), em feijoeiro irrigado. cultivar LAC-Carioca em rotação com milho, mucuna preta, lablabe, milho + mucuna preta e milho - lablabe. 
Embora as diferenças entre os tratamentos não tenham sido significativas, nos tratamentos com pousio e guandu, particularmente em 1995, os teores de fósforo foram numericamente os menores (tabela 11). Assim é que, a cultura do feijoeiro após o guandu não pareceu ser beneficiada por uma possivel maior solubilizaçào do fósforo, combinado ao ferro e ao alumínio, por meio de ácidos piscídicos e seus derivados $\mathrm{p}+\mathrm{O}$ metil, exudados por este adubo verde, conforme relatado nos estudos de Ae et al., (1990). Ainda, apesar dos teores deste elemento no solo serem considerados médios, foram numericamente inferiores aos demais tratamentos em 1994 e 1995 (tabelas 7 e 8).

Cabe destacar que, em função do atraso verificado nas datas de semeadura das diferentes culturas durante $o$ ano e ao longo dos mesmos. contrariando a programação previamente estabelecida, o guandu foi cultivado de abril a julho em $1994 \mathrm{e}$ 1995. Nessa época o desenvolvimento de suas plantas não foi favorecido. concordando com Otani \& Ae (1997), segundo os quais, a exudação de àcidos orgànicos quelantes pelas raizes do guandu não seria controlada pela deficiência de fỏsforo e sim pelo estágio de desenvolvimento da planta. Para as demais leguminosas do presente trabalho, quais sejam, a crotalária júncea e a mucuna preta, admitem-se semeaduras mais tardias, conforme Bulisani \& Roston (1993).

No tratamento com pousio tambem houve uma interrupçào da adubação química com NPK neste ciclo de não ocupação da área. o que não ocorreu apenas no tratamento em que o milho antecedeu o feijoeiro.

Em relação aos teores foliares de potássio (tabela 11). estes podem ser considerados adequados, em concordância com Hiroce et al. (1969). Piggot (1986) e Wilcox \& Fageria (1976). Foram inferiores, entretanto, em relaçào aos niveis estabelecidos por Gallo \& Miyasaka (1961), Haag et al. (1967). Malavolta (1969). Ainda. em ambos os anos, nos tratamentos em que o feijoeiro sucedeu as leguminosas, e em 1994, no tratamento com milho, os teores foliares situaram-se um pouco acima do limite inferior da faixa considerada adequada por Ambrosano et al. (1996): Benton Jones et al. (1991) e Malavolta (1987).

Não houve diferenças estatisticas entre anos e nem entre tratamento $x$ ano. Entretanto, observaram-se diferenças entre os tratamentos. sendo que apenas os valores 
dos tratamentos em que a mucuna preta e a crotalária juncea antecederam o feijoeiro diferiram significativamente do pousio, indicando uma maior capacidade de aproveitamento deste elemento quando estas duas leguminosas são incluidas no esquema de rotação de culturas. Coincidentemente, tambem os teores de potássio determinados nas análises de solo (tabelas 6,7 e 8) apresentaram uma tendència para maiores valores nos tratamentos com as leguminosas, sobretudo em 1993 e 1994 e na média dos anos, corroborando os resultados obtidos por Miyasaka et al. (1966a). em pesquisas sobre efeitos da incorporação de matéria orgânica imediatamente antes da semeadura do feijoeiro, e também por Hiroce et al. (1969), em diagnose foliar, em estudos complementares aos de Miyasaka et al. (1966a).

Arf et al. (1996) obtiveram valores superiores em folhas de feijoeiro irrigado, cultivar IAC-Carioca, em rotação com gramineas e leguminosas. destacando-se o tratamento em que a mucuna preta, em cultivo exclusivo, antecedeu a cultura do feijoeiro.

Como os teores de potássio determinados no solo tambem foram considerados adequados (tabelas 6,7 e 8), assume-se que a adubação quimica garantiu a manutenção dos teores foliares do elemento, dentro de determinados limites (tabela 11) Ainda, como o teor de matéria orgânica no solo foi considerado normal (tabelas 6. 7 e 8). a solubilização do potássio e sua assimilação pelo feijoeiro podem ter sido favorecidas por essa matéria orgânica, conforme salientado por Aslander \& Armolik (1965)

Lunin et al. (1964b) determinaram que a adubaçào NPK nào afetava consideravelmente o acúmulo de cátions, exceto do potassio e que essa adubação. quando associada à calagem, não alterava substancialmente o teor dos elementos nitrogênio, fósforo e potássio nas plantas de feijoeiro. Hiroce et al (1969). entretanto. não observaram eficiência da adubação potássica no teor desse elemento nas folhas dessa leguminosa.

O crescimento normal do feijoeiro em condiçōes de baixos niveis de potássio disponivel estaria mais relacionado à eficiência no uso desse elemento no interior da planta do que a uma assimilação mais intensa (Shea et al. 1967). 
Os teores de cálcio e os de magnésio determinados na matéria seca das folhas de feijoeiro foram significativamente maiores em 1995 do que em 1994, em ambos os anos (tabela 11). Foram considerados adequados, em todos os tratamentos, conforme critérios de diversos autores (Ambrosano et al., 1996; Benton Jones et al., 1991: Gallo \& Miyasaka, 1961; Wilcox \& Fageria, 1976), sendo similares aos obtidos por Arf et al. (1996).

De acordo com outros autores porém, a adequaçào dos resultados foi variável. Assim, os teores de cálcio continuaram sendo adequados em ambos os anos, conforme Hiroce et al. (1970), Malavolta (1987) e Piggott (1986): apenas em 1995 para Fageria et al. (1991), Rosolem \& Marubayashi (1994) e Wilcox \& Fageria (1979), e inadequados em ambos os anos segundo Cobra Neto (1967) e Haag et al. (1967), embora não o fossem ao nivel de deficiência estabelecido por Cobra Neto (1967).

Como o cálcio é um elemento não sujeito à mobilização interna significativa a partir das folhas, espera-se que a quantidades acumulada nestas nào seja redistribuida a fim de suprir suficientemente outras folhas em periodos subsequentes. Esse fato indica a dependência do crescimento da planta em relaçāo ao cálcio absorvido continuadamente do meio, sendo pouco mobilizado de deposiçòes anteriores (Biddulph et al., 1959 e 1961).

Apesar da diminuição do teor de cálcio em profundidade no perfil do solo (tabelas 6, 7 e 8), não se observou decréscimo correspondente nas plantas. evidenciando teores acima do nivel exigido no solo para que as plantas atingissem seu crescimento. Não se verificou efeito da interação tratamento $x$ ano. mas observaram-se diferenças significativas entre os tratamentos, sendo que houve um maior acumulo foliar de calcio naqueles em que as leguminosas mucuna preta e guandu antecederam o feijoeiro. Estes valores foram superiores aos demais e estatisticamente diferentes do pousio, concordando com a tendência relatada por Igarashi et al. (1997).

Por sua vez, os teores de magnesio tambem foram adequados em ambos os anos, segundo Haag et al. (1967), Fageria et al. (1991). Rosolem \& Marubayashi (1994) e Wilcox \& Fageria (1979) e, apenas em 1995. de acordo com Hiroce et al. 
(1970), Malavolta (1987) e Piggott (1986). Segundo Cobra Neto (1967), foram inadequados em ambos os anos.

Não se observaram diferenças significativas entre os valores de magnésio dos tratamentos nem na interação tratamento $\mathrm{x}$ ano. Estes resultados foram cerca de 1,5 a 2,0 vezes superiores aos relatados por Arf et al. (1996) em feijoeiro irrigado, cultivar IAC-Carioca, após rotação com gramíneas e adubos verdes.

Em feijoeiro, cultivar Carioca, Bulisani (1994) observou acúmulo do cálcio e do magnésio absorvidos, este último em menor intensidade, principalmente nas folhas, os quais não são totalmente exportados. Segundo Carolus (1938), a adição de cálcio ao solo não apenas acentua sua absorção pelo feijoeiro como também pode colaborar para uma maior absorção do magnésio, sendo até mesmo ligeiramente benéfica à absorção de potássio. Bulisani (1994) observou absorção de quantidades quase semelhantes às de cálcio e potássio por plantas de feijoeiro, cultivar Carioca, tendência essa que foi observada também neste estudo para o ano de 1994 (tabela 11). Conforme Lunin et al. (1964 a,b), a quantidade de cálcio e de magnésio na planta aerea de plantas de feijoeiro está estreitamente relacionada aos seus teores no substrato.

Os teores foliares de enxofre foram considerados adequados em todos os tratamentos e anos de acordo com a maioria dos autores (Ambrosano et al., 1996; Fageria et al., 1991; Gallo \& Miyasaka, 1961; Haag et al., 1967: Piggott. 1986: Rosolem \& Marubayashi, 1994), sendo estatisticamente diferentes entre anos e entre tratamentos (tabela 11). Segundo critérios de Malavolta (1987) entretanto. so foram considerados adequados no tratamento com a mucuna preta em 1994 e em todos os tratamentos em 1995, sendo ainda deficientes em ambos os anos e em todos os tratamentos conforme Cobra Neto et al. (1971). A interação tratamento $\mathrm{x}$ ano não foi significativa e o tratamento com mucuna preta diferiu apenas daqueles com crotalária jüncea e guandu.

O principal reservatório de enxofre no solo é a matéria orgânica e, como no presente estudo os teores desta foram considerados normais (tabelas 6.7 e 8), pode-se dizer que os teores foliares detectados (tabela 11) coadunaram-se com o esperado, ou seja, a matéria orgânica do solo foi uma fonte adequada do elemento enxofre para o feijoeiro, independente dos tratamentos e dos anos. Coincidentemente, nos tratamentos 
com mucuna preta e aveia preta, o teor de materia orgânica no solo e também os de enxofre na matéria seca das folhas foram maiores em relação aos demais nos dois anos. Em suas pesquisas de rotaçâo com o feijoeiro irrigado. Arf et al. (1996) obtiveram valores foliares muito inferiores, tanto de enxofre quanto de materia orgânica.

\subsection{Cobertura vegetal do solo}

Os dados de cobertura percentual de solo pela fitomassa de feijoeiro estão relacionados na tabela 12 .

Não se observaram diferenças estatisticas entre tratamentos e nem entre anos. A interação tratamento $\mathrm{x}$ ano, entretanto, foi significativa fazendo com que os resultados de cada ano fossem interpretados separadamente.

Em 1994 os maiores valores foram verificados nos tratamentos em que a crotalária juncea e a mucuna preta antecederam o feijoeiro. diferindo significativamente do pousio e dos demais. No tratamento com a aveia preta houve a cobertura de solo menos eficiente $(74,1 \%)$.

Tabela 12: Cobertura do solo por plantas de feijoeiro. cultivar IAC-Carioca no estádio $\mathrm{R}_{7 \text {; }}$ após rotação com milho/culturas graniferas e adubos verdes. Ribeirão Preto, São Paulo, 1994 e 1995

\begin{tabular}{lccc}
\hline $\begin{array}{c}\text { Cultura anterior ao } \\
\text { feijoeiro }\end{array}$ & $\mathbf{1 9 9 4}$ & 1995 & Média \\
\hline Pousio & $83,6 \mathrm{~b}$ & $82.5 \mathrm{c}$ & $\mathbf{8 3 . 0}$ \\
Milho & $85,1 \mathrm{~b}$ & $83.7 \mathrm{bc}$ & $\mathbf{8 4 . 3}$ \\
Aveia preta & $74,1 \mathrm{c}$ & $85.7 \mathrm{bc}$ & $\mathbf{8 0 . 2}$ \\
Crotalaria juncea L. & $93,2 \mathrm{a}$ & $90,3 \mathrm{ab}$ & $\mathbf{9 1 . 8}$ \\
Guandu & $85,5 \mathrm{~b}$ & $87,7 \mathrm{abc}$ & $\mathbf{8 6 , 6}$ \\
Mucuna preta & $92,6 \mathrm{a}$ & $92.7 \mathrm{a}$ & $\mathbf{9 2 . 6}$ \\
\hline Média & $\mathbf{8 5 , 7}$ & $\mathbf{8 7 . 1 \mathrm { A }}$ & \\
\hline CV(\%) & $-\cdots$ & \\
\hline
\end{tabular}

Médias seguidas pelas mesmas letras minúsculas nas colunas e maiusculas nas línhas nào diferem entre si pelo teste de Duncan a $5 \%$. 
Em 1995 obteve-se uma cobertura mais eficiente do solo $(92,7 \%)$ no tratamento com a mucuna preta, cujo valor diferiu significativamente dos tratamentos com milho, aveia preta e, sobretudo do pousio, em que se observou o menor valor de cobertura $(82,5 \%)$.

De maneira geral, à exceção dos tratamentos cultivados anteriormente com mucuna preta e crotalária juncea, em que se observam valores de cobertura do solo superiores a $90,0 \%$ nos dois anos, nos demais tratamentos não houve uma cobertura eficiente, conforme preconizado por Bulisani et al. (1987), Fancelli $(1997)^{+}$e Lollato $(1997)^{5}$. Segundo esses autores, deve ocorrer o recobrimento total da area de cultivo no início do florescimento das plantas de feijoeiro. com vistas à manutenção da produtividade da cultura e otimização do seu rendimento.

De acordo com os resultados obtidos. obsena-se uma tendència para a obtenção de maiores valores de recobrimento de solo naquelas parcelas em que as leguminosas antecederam o feijoeiro, notadamente a crotalaria juncea e a mucuna preta. em relação às gramíneas e ao pousio. Coincidentemente, naqueles tratamentos em que houve destaque para essa característica (tabela 12), tambem o houve para os parâmetros quantidade de matéria seca (tabela 13), IAF (tabela 14). desenvolvimento do sistema radicular (tabela 16) e rendimento em grãos (tabela 19). sugerindo uma associação entre as mesmas.

Os coeficientes apresentados na tabela 20 e discutidos posteriormente entretanto, não apresentaram correlação linear para a maioria das comparaçôes com o parâmetro em questão, à exceção daquela com o rendimento em gràos. cujos valores. embora não significativos, aproximaram-se do limite de significància a $5 \%$.

Provavelmente, os efeitos físicos dos residuos vegetais incorporados, sobretudo das leguminosas anteriormente citadas, tenham propiciado condiçòes mais favoráveis para o crescimento e o desenvolvimento das plantas de feijoeiro, concordando com os resultados positivos obtidos nesta cultura por Almeida et al. (1971). Mascarenhas

\footnotetext{
${ }^{4}$ Fancelli. A. L. ESALQ/USP, Piracicaba. In: Simpósio sobre a cultura de feijào irngado. 4. Piracicaba. 1997 (Palestra).

${ }^{5}$ Lollato. M.A. IAPAR. Londrina. In: Simpósio sobre a cultura de fajiào irngado. 4. Piracicaba. 1997 (Palestra).
} 
et al (1967a,b), Menegario (1964), Miyasaka et al. (1966a d) e ainda, conforme literatura compilada por Vieira (1967).

O valor prático e de interesse agricola desse paràmetro consiste na contribuição efetiva dessa maior superficie foliar na interceptação de energia radiante incidente para a fotossíntese, até um determinado limite, com conseqüente conversão em matéria seca assimilada e incremento na taxa de crescimento total da planta Monteith, 1965; Wit, 1958). Ainda, evita-se tanto a perda de água sem uso pelas plantas e a de solo exposto por ação das chuvas e erosão (Wischmeier, 1975), quanto o estabelecimento de uma competição com plantas infestantes emergentes (Bulisani et al., 1987).

\subsection{Quantidade de matéria seca}

Os valores de quantidade de matéria seca da parte aerea de plantas de feijoeiro, na fase de florescimento pleno e inicio de formaçào de vagens (R7) estão relacionados na tabela 13 .

A época de amostragem adotada nos dois anos agricolas - ao redor dos 60 dias do ciclo das plantas, foi coincidente com as determinaçōes de diversos autores, nas mais variadas condições de cultivo (Brandes, 1971; Bulisani, 1994; Cobra Neto, 1967 ; Demattê et al., 1974; Haag et al., 1967; Mafra et al., 1971).

Segundo Lopes \& Miglioranza (1993) os maximos teores de carboidratos solúveis totais na folha foram verificados no estadio $R_{\text {-. }}$ cerca de duas semanas antes dos máximos relatados na raiz e no caule

Em suas pesquisas, Lucas et al. (1976) confirmaram que no feijoeiro. assim como em outras leguminosas, a principal fonte de assimilados para a produção de sementes é obtida no periodo de pós-florescimento, quando para alta produção, não sendo proveniente de material acumulado no caule ou nas raizes como reserva durante o periodo vegetativo. 
Tabela 13: Quantidade de matéria seca da parte aérea de plantas de feijoeiro,cultivar IAC-Carioca, no estádio $\mathrm{R}_{7}$, após rotação com milho/culturas graniferas e adubos verdes. Ribeirão Preto, São Paulo. 1994 e 1995.

\begin{tabular}{|c|c|c|c|}
\hline Cultura Anterior & $1994^{(1)}$ & $1995^{\text {(I) }}$ & MÉDIA \\
\hline Pousio & 209,88 & $\begin{array}{l}-\mathrm{g} / \mathrm{m}^{-} \\
169,91\end{array}$ & 189,89 \\
\hline Milho & 225,52 & 180,70 & $203,11 \mathrm{~g}$ \\
\hline Aveia preta & 216,20 & 196,10 & 206.15 \\
\hline Crotalaria juncea $\mathbf{L}$. & 223,98 & 203.82 & 213,90 \\
\hline Guandu & 203,81 & 165,77 & 184,79 \\
\hline Mucuna preta & 249,80 & 188.26 & $219.03 \mathrm{~g}$ \\
\hline Média & $221,53 \mathrm{~A}$ & $184.09 \mathrm{~B}$ & $\ldots$ \\
\hline CV $(\%)$ & 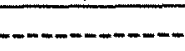 & m. & \\
\hline
\end{tabular}

Médias seguidas pelas mesmas letras minúsculas nas colunas e maiusculas nas linhas nào diferem entre si pelo teste de Duncan a $5 \%$.

(1) avaliação aos 59 dias após a semeadura: (2) avaliação aos 61 dias apos a semeadura.

No presente trabalho, o florescimento pleno das plantas ocorreu, em média, aos 60 dias após a semeadura (tabela 3), concordando com resultados obtidos também para o cultivar IAC-Carioca, por Lemos (1995) e tambem por Nogueira (1990) e Vieira (1988). As observações de Nogueira (1990) e de Lemos (1995). inclusive, foram realizadas na safra "de inverno", no municipio de Jaboricabal. que esta situado bem próximo ao de Ribeirão Preto, em São Paulo.

Não foram observadas diferenças significativas entre tratamentos e nem na interação tratamento $\mathrm{x}$ ano. Entretanto, os resultados obtidos em 1994 diferiram significativamente daqueles de 1995 (tabela 13).

Esse maior desenvolvimento vegetativo obseriado em 1994 se deve ao fato da semeadura do feijoeiro ter sido realizada no inicio de agosto. Em 1995, esta se deu somente no final de setembro em 1995, que é o prazo limitrofe para a safra "das águas" naquela região, conforme estabelecido mais recentemente no zoneamento ecológico para o feijoeiro no Estado de São Paulo (Pinzan et al. 1994).

Os resultados médios de 1994 assemelham-se aos valores observados por Gallo \& Miyasaka (1961), que variaram entre 227,5 a $218.0 \mathrm{~g} \mathrm{~m}^{2}$, aos 53 e 65 dias. 
respectivamente, sendo superiores aos $160 \mathrm{~g} / \mathrm{m}^{2}$ obtidos por Portes (1996), em cultivar Carioca que recebeu adubação e irrigação.

Por sua vez, Bulisani (1994), Haag et al. (1967) e Montojos \& Magalhães (1971) observaram resultados superiores. Entretanto, em uma das situações, apesar dos dados terem obtidos em condições de campo, a quantidade de matéria seca das raizes foi inclúida e não discriminada do total (300 a $350 \mathrm{~g} / \mathrm{m}^{2}$ ) (Montojos \& Magalhães, 1971). Nos outros trabalhos (Bulisani, 1994; Haag et al, 1967), as pesquisas foram desenvolvidas em casa de vegetação, com duas plantas por vaso, e provavelmente houve um efeito compensatório, sob certos limites, do crescimento individual a uma maior ou menor população de plantas. Conforme Brandes (1971), o crescimento individual de plantas de feijoeiro é inversamente proporcional às densidades de semeadura.

Em relação aos dois anos de estudos, a quantidade de materia seca determinada na parte aérea das plantas seguiu o mesmo padrào do indice de area foliar (IAF) (tabela 14) e do rendimento em grãos (tabela 19). Em média todos esses parâmetros apresentaram valores maiores em 1994 do que em 1995.

As correlações significativas entre quantidades de matéria seca e IAF nos dois anos (tabela 20) e entre IAF e rendimento em grãos em 1995 (tabela 20) são coerentes com a tendência observada, corroborando os resultados obtidos em feijoeiro (Stone et al., 1990) e também em soja (Nogueira, 1983).

A redução na produção de matéria seca em feijoeiro deve-se à diminuição em sua área foliar e portanto, na taxa assimilatoria liquida (Stone et al., 1990. Thung et al., 1990). Com isso, o IAF máximo é menor com conseqüente influència direta no rendimento em grãos, uma vez que este parâmetro é altamente correlacionado com a duração da área foliar (Stone et al., 1990).

Como a folha é o principal local da fotossintese na planta a taxa de produção de matéria seca pelas comunidades vegetais é função da superficie foliar produzida sobre determinada área de solo (Shibles \& Weber, 1965), porem, até um determinado valor (Brougham, 1958). 


\section{7. Índice de área foliar}

Os valores de indice de área foliar (IAF) estão relacionados na tabela 14 .

A avaliação nesse trabalho foi realizada aos 60 dias do ciclo, quando as plantas estavam no seu florescimento pleno e formação de vagens (R7). Jones (1971) afirmou ser o rendimento de Phaseolus dependente do valor de IAF no florescimento. Magalhães e Montojos (1971), Portes (1996) e Sondahl et al. (1971) obtiveram valores máximos desse parâmetro para o cultivar Carioca imediatamente após o pleno florescimento (cerca de 55 a 60 dias), quando as folhas estariam mais envolvidas no suprimento de reservas para os grãos, caracterizando uma situação de maior eficiència fotossintética com conseqüente maior rendimento em gràos (Magalhães e Montojos, 1971). Também Bulisani (1994) obteve maiores valores de area foliar para esse mesmo cultivar aos 60 dias.

No presente trabalho não houve diferenças significativas entre anos e nem para a interação tratamento $\mathrm{x}$ ano porém, estas foram obseradas entre os tratamentos. Os resultados médios nos tratamentos com mucuna preta e crotalaria juncea diferiram significativamente do pousio. Magalhães et al. (1971) tambem obtiveram valores de IAF bastante elevados quando havia incorporação de materia orgânica no solo.

Tabela 14: Índices de área foliar (IAF) de plantas de feijoeiro, cultivar IAC-Carioca no estádio $R_{6}$ para $R_{7}$, após rotação com milho culturas graniferas e adubos verdes. Ribeirão Preto, São Paulo, 1994 e 1995

\begin{tabular}{|c|c|c|c|}
\hline $\begin{array}{c}\text { Cultura anterior ao } \\
\text { feijoeiro }\end{array}$ & 1994 & 1995 & Média \\
\hline Pousio & 2,10 & 2,07 & $2.08 \mathrm{c}$ \\
\hline Milho & 2,13 & 2.20 & $2,16 \mathrm{bc}$ \\
\hline Aveia preta & 2,13 & 2.27 & $2.20 \mathrm{bc}$ \\
\hline Crotalaria juncea L. & 2,48 & 2,33 & $2.41 \mathrm{ab}$ \\
\hline Guandu & 2,04 & 1,91 & $1,97 \mathrm{c}$ \\
\hline Mucuna preta & 2,67 & 2.29 & $2.48 \mathrm{a}$ \\
\hline Média & $2,26 \mathrm{~A}$ & $2.18 \mathrm{~A}$ & $-\cdots$ \\
\hline $\mathrm{CV}(\%)$ & 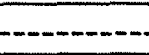 & $-\infty$ & \\
\hline
\end{tabular}

Médias seguidas pelas mesmas letras minúsculas nas colunas e maiusculas nas linhas não diferem entre si pelo teste de Duncan a $5 \%$. 
Considerando-se os dois anos e todos os tratamentos. a faixa de variação do IAF foi de 1,91 a 2,67 .

A planta de feijoeiro é considerada como de baixa eficiència fotossintética, apresentando valores de IAF inferiores a 4,0 (Alvim \& Alvin, 1969. Brandes, 1971) e os resultados apresentados na tabela 14 estão de acordo com aqueles obtidos por Alvim \& Alvim (1965), Portes (1996) e White \& Izquierdo (1991). São, ainda, superiores aos relatados por Bergamaschi et al. (1997), para plantas do cultivar Aroana de hábito de crescimento indeterminado, tipo II, na fase de pleno florescimento (1.80): por Jara (1985) (entre 1,57 e 1,93) e por Portes et al. (1980), para o cultivar Carioca, sob luz plena $(1,2)$. Faria et al. (1997), entretanto, obtiveram valores de LAF da ordem de 3.6 e 3.2 aos 69 dias, respectivamente para os cultivares IAPAR-14 e IAPAR-57. ambos com grãos do tipo Carioca e hábitos de crescimento do tipo II. semeados em um mès de agosto.

As altas correlações verificadas entre IAF e quantidade de materia seca na parte aérea das plantas de feijoeiro (tabela 20) sâo indicativas da tendència para mesmo padrão de variação desses parâmetros. Em relação ao rendimento. obseriou-se uma correlação positiva em 1995 e, embora não tenha sido significativa em 1994, seu valor se aproximou do limite de significância, sugerindo uma forte associação entre ambos, conforme observado por Duarte \& Adams (1972). Jones (1971) e por Montojos \& Magalhães (1971)

Estudando as bases fisiologicas dos diferentes rendimentos, por meio da análise de crescimento em seis cultivares de feijoeiro. Wallace \& Munger (1965) observaram que aqueles com maiores valores de rendimento tambem o foram para area foliar e razão de área foliar. Brougham (1956) mostrou que a percentagem de interceptação de luz e a taxa de produção de materia seca aumentam com a área foliar.

Embora as correlações entre IAF e altura de plantas nào tenham sido siginificativas (tabela 20), em 1994, concordando com as observaçooes de Silva et al (1982), em média, essas duas caracteristicas apresentaram valores um pouco maiores do que em 1995. Segundo Gabelmam \& Williams (1960). a maior causa da diminuição do rendimento em grãos em feijoeiro seria a redução em sua area foliar e na altura da planta. sendo então observada abscisão de elevada percentagem de flores e de vagens pequenas. 
Ainda, a correlação entre a área foliar e o rendimento em grãos pode ser tanto positiva quanto negativa, dependendo das condiçòes climáticas (Hunt, 1978), sobretudo na fase de formação de vagens (Davis, 1945). No presente trabalho, essa correlação não foi significativa apenas em 1994 (tabela 20), mas apresentou-se alta em 1995, concordando com Stone et al. (1990).

Segundo Portes \& Carvalho (1983), o ciclo de produção de folhas em feijoeiro, considerada como duração de área foliar (DAF) segue uma tendência de aumento no sentido dos cultivares com hábitos de crescimento do tipo I para o IV. O aumento correspondente em grãos, entretanto, nào ocorre na mesma proporçào (Laing et al., 1984). Isso porque essa relação depende da eficiència da area foliar. que relaciona as características mencionadas e o DAF. Segundo Davis (1945), a area foliar em feijoeiro no florescimento de suas plantas está sob grande influència de condiçòes ambientais, sobretudo da temperatura máxima e da umidade relativa minima.

Alguns autores discordam quanto à narureza da resposta fotossintética a uma possivel IAF excedente e àquele requerido para um maximo rendimento. Há os que apóiam a sua ocorrência e os que the são contrários, conforme Shibles \& Weber (1965) e diversos autores mencionados em Nogueira (1983), Segundo Shibles \& Weber (1965), na cultura da soja é importante que se saiba inclusive a resposta basica de cada cultivar ao IAF máximo e aquele de importância biologica e econòmica

\subsection{Altura de plantas}

Os resultados de avaliação de altura de plantas de feijoeiro ao final do enchimento de vagens (R8) estão relacionados na tabela 15. não sendo observadas diferenças estatísticas entre os tratamentos, entre anos e nem na interaçào tratamento $\mathrm{x}$ ano.

A correlação entre os valores de altura e os de rendimento em gràos para 1994 (tabela 20) foi positiva e elevada, concordando com observaçòes obtidas no CIAT, na Colômbia, em 1975. 
Tabela 15: Altura de plantas de feijoeiro, cultivar IAC-Carioca, no estádio $\mathrm{R}_{8}$, após rotação com milho/culturas graniferas e adubos verdes. Ribeirão Preto, São Paulo, 1993, 1994 e 1995.

\begin{tabular}{|c|c|c|c|c|}
\hline $\begin{array}{c}\text { Cultura anterior ao } \\
\text { feijoeiro }\end{array}$ & 1993 & 1994 & 1995 & Média \\
\hline Pousio & 70,8 & 68,7 & 69,5 & $69,7 \mathrm{a}$ \\
\hline Milho & 72,6 & 69,3 & 69.5 & $70,5 \mathrm{a}$ \\
\hline Aveia preta & 67,4 & 63,5 & 69.9 & $67,0 \mathrm{a}$ \\
\hline Crotalaria juncea L. & 71,5 & 73,4 & 67,3 & $70,7 \mathrm{a}$ \\
\hline Guandu & 70,9 & 68,9 & 65,3 & $68,4 a$ \\
\hline Mucuna preta & 72,0 & 70.0 & 67.9 & $70,0 \mathrm{a}$ \\
\hline Média & $70,8 \mathrm{~A}$ & $69.0 \mathrm{~A}$ & $68,3 \mathrm{~A}$ & $-\cdots-$ \\
\hline $\mathrm{CV}(\%)$ & $-\cdots$ & $-6,4-\cdots$ & $-\cdots$ & \\
\hline
\end{tabular}

Médias seguidas pelas mesmas letras minúsculas nas colunas e maiusculas nas linhas não diferem entre si pelo teste de Duncan a $5 \%$.

Segundo Gabelman \& Williams (1960). a altura de plantas em feijoeiro é um importante fator determinante do rendimento, tanto direta quanto indiretamente. Conforme Emerson (1916), o número de internódios e o comprimento das plantas de feijoeiro são características de herança quantitativa. estando esta ultima sujeita aos efeitos de condições ambientais. Por outro lado, esta correlação pode vir a ser negativa de acordo com informações de Davis \& Evans (1977) ou ainda nào significativa, conforme os resultados obtidos nos anos de 1993 e 1995 (tabela 20).

Ainda, embora não tenham sido observadas correlaçòes entre altura e quantidade de matéria seca e IAF (tabela 20), na maioria dos tratamentos e na média dos anos houve uma tendência para valores superiores entre essas comparaçōes. Segundo Thung et al. (1990), sob condições adequadas para um bom desenvokimento das plantas de feijoeiro, estas apresentam valores maiores para altura area foliar e produçào de matéria seca na parte aérea.

Em feijoeiro a altura pode variar entre 22 e $220 \mathrm{~cm}$ de acordo com estudos realizados em 2.216 introduções dessa especie no CIAT. Colòmbia. e mencionados em Pompeu (1987) e em Vieira (1978). Nos resultados obtidos por Paredes et al. (1989) a altura de plantas de feijoeiro com hábito de crescimento indeterminado do 
tipo III variou de 40 a $60 \mathrm{~cm}$. Para o cultivar IAC-Carioca SH, que apresenta porte médio e hábito de crescimento indeterminado do tipo III, há registros de valores desde 50 cm (DSMM, 1991) ${ }^{6}$ até $103 \mathrm{~cm}$ (Santos et al., 1988).

Como essas informações não precisaram a extensào da medida realizada, se na altura do dossel ou na extremidade da guia da planta os valores médios apresentados na tabela 15 , que estão ao redor de $70 \mathrm{~cm}$, encontram-se na amplitude de variação desse parâmetro. Cabe salientar, entretanto, que condiçôes ambientais como fertilidade do solo, fotoperiodo, luz, temperatura e disponibilidade de agua no solo, dentre outras, podem interferir na expressividade dessa caracteristica (Emerson, 1916) (Pompeu, 1997) ${ }^{7}$.

\subsection{Desenvolvimento do sistema radicular}

\subsubsection{Comprimento de raizes}

Os resultados da avaliação da densidade de comprimento do sistema radicular do feijoeiro, cultivar IAC-Carioca, em diferentes profundidades e. em très anos agricolas, estão apresentados na tabela 16 .

Essa avaliação foi realizada ao redor de 60 dias do ciclo. quando as plantas estavam em pleno florescimento e inicio de formação de vagens (estadio $R_{7}$ ) Nessa ocasião, o sistema radicular do feijoeiro está em seu desenvolvimento maximo. concordando com o observado por Pires et al. (1991).

Verificou-se uma maior concentração de raizes do feijoeiro nas camadas superficiais, com diminuição gradual em profundidade. independente do ano e das culturas antecedentes, similarmente ao observado por Pires et al. (1991) e por Guimaràes et al. (1996), em feijoeiro irrigado, respectivamente. cultivares Carioca-80 e Carioca, sob preparo convencional.

\footnotetext{
${ }^{6}$ DSMM - Departamento de Sementes. Mudas e Matrizes. CATI. Feiiào IAC-Carioca. Secretaria de Agricultura e Abastecimento. Campinas. São Paulo. 1991. (Folder)

Pompeu. A.S. Seção de Genética. IAC. Comunicação pessoal. 1997.
} 
Tabela 16: Densidade de comprimento e o respectivo erro padrão de raizes finas de feijoeiro, cultivar IAC-Carioca, no estádio $\mathbf{R}_{7}$, após rotação com milho/culturas graniferas e adubos verdes e em diferentes profundidades. Ribeirão Preto, SP, 1993, 1994 e 1995

\begin{tabular}{|c|c|c|c|c|c|c|c|}
\hline \multirow{2}{*}{$\begin{array}{l}\text { Profun- } \\
\text { didade }\end{array}$} & \multicolumn{6}{|c|}{ Cultura anterior ao feijoeiro } & \multirow[t]{2}{*}{ Média } \\
\hline & Pousio & Milho & Aveia preta & $\begin{array}{c}\text { Crotalaria } \\
\text { juncea }\end{array}$ & Guandu & $\begin{array}{c}\text { Mucuna } \\
\text { preta }\end{array}$ & \\
\hline$-\mathrm{cm}-$ & & & $-\mathrm{cm} /$ & & & & \\
\hline $\begin{array}{r}0-10 \\
10-20 \\
20-30 \\
30-40 \\
40-50 \\
50-60\end{array}$ & $\begin{array}{l}0,16 \pm 0,03 \\
0,14 \pm 0,01 \\
0,11 \pm 0,03 \\
0,10 \pm 0,03 \\
0,08 \pm 0,01 \\
0,05 \pm 0,02\end{array}$ & $\begin{array}{l}0,15 \pm 0,03 \\
0,10 \pm 0,02 \\
0,11 \pm 0,03 \\
0,07 \pm 0,01 \\
0,08 \pm 0,01 \\
0,10 \pm 0,02\end{array}$ & $\begin{array}{l}0,18 \pm 0,04 \\
0,16 \pm 0,02 \\
0,12 \pm 0,03 \\
0,10 \pm 0,01 \\
0,09 \pm 0,01 \\
0,05 \pm 0,01\end{array}$ & $\begin{array}{l}0,21 \pm 0,04 \\
0,14 \pm 0,09 \\
0,09 \pm 0,03 \\
0,08 \pm 0,02 \\
0,07 \pm 0,01 \\
0,05 \pm 0,02\end{array}$ & $\bar{\square}$ & $\begin{array}{l}0,11 \pm 0,01 \\
0,09 \pm 0,01 \\
0.07 \pm 0,01 \\
0,06 \pm 0,01 \\
0.04 \pm 0,03 \\
0.03 \pm 0.01\end{array}$ & $\begin{array}{l}0,162 \mathrm{a} \\
0,127 \mathrm{~b} \\
0,100 \mathrm{c} \\
0,082 \mathrm{~cd} \\
0,072 \mathrm{~cd} \\
0,056 \mathrm{~d}\end{array}$ \\
\hline Total & $0,64 \mathrm{~A}$ & $0,61 \mathrm{~A}$ & $0,70 \mathrm{~A}$ & $0,64 \mathrm{~A}$ & $\overline{--n}$ & $0.40 \mathrm{~B}$ & ---1 \\
\hline
\end{tabular}

1994

\begin{tabular}{|c|c|c|c|c|c|c|c|}
\hline $0-10$ & $0, \overline{45 \pm 0}, \overline{0} \overline{9}$ & $0,48 \pm 0,1$ & $0,49 \pm 0,05$ & $0,54 \pm 0, \overline{1}$ & $0,41=0,02$ & $0,72 \pm 0,12$ & $0,514 \mathrm{a}$ \\
\hline $10-20$ & $0,35 \pm 0,09$ & $0,36 \pm 0,05$ & $0,34 \pm 0,02$ & $0,40 \pm 0,07$ & $0.40=0.07$ & $0,33 \pm 0.05$ & $0.365 \mathrm{~b}$ \\
\hline $20-30$ & $0,22 \pm 0,04$ & $0,28 \pm 0,05$ & $0,28 \pm 0,02$ & $0,26=0,05$ & $0.24=0,02$ & $0,29 \pm 0.01$ & $0,261 \mathrm{c}$ \\
\hline $30-40$ & $0,18 \pm 0,04$ & $0,24 \pm 0,03$ & $0,14 \pm 0,03$ & $0,20 \pm 0,03$ & $0,13=0,00$ & $0.25 \pm 0.01$ & $0,189 d$ \\
\hline $40-50$ & $0,17 \pm 0,09$ & $0,12 \pm 0,05$ & $0,09 \pm 0,03$ & $0,17=0,02$ & $0,07=0,04$ & $0.11=0.02$ & 0,123 e \\
\hline $50-60$ & $0,09 \pm 0,04$ & $0,12 \pm 0,02$ & $0,04 \pm 0,02$ & $0.08 \pm 0.02$ & $0.06=0.05$ & $0.04 \pm 0.02$ & $0,071 \mathrm{e}$ \\
\hline Total & $1,46 \mathrm{~A}$ & $1,60 \mathrm{~A}$ & $1,38 \mathrm{~A}$ & $1.65 \mathrm{~A}$ & $1.31 \mathrm{~A}$ & $1.74 \mathrm{~A}$ & $F$ \\
\hline
\end{tabular}

1995

\begin{tabular}{|c|c|c|c|c|c|c|c|}
\hline $0-10$ & $0,23 \pm 0,03$ & $0,34 \pm 0,13$ & $0,29 \pm 0,06$ & $0,38 \pm 0,12$ & $0,28=0,04$ & $0,34 \pm 0,08$ & 0,310 a \\
\hline $10-20$ & $0,19 \pm 0,06$ & $0,16 \pm 0,03$ & $0,16 \pm 0,03$ & $0,16 \pm 0,04$ & $0,17 \pm 0,03$ & $0.21 \pm 0.02$ & $0,177 b$ \\
\hline $20-30$ & $0,14 \pm 0,04$ & $0,14 \pm 0,01$ & $0,15 \pm 0,02$ & $0,15 \pm 0,02$ & $0,15 \pm 0,02$ & $0.15=$ & $\$ 7$ bc \\
\hline $30-40$ & $0,13 \pm 0,05$ & $0,14 \pm 0,01$ & $0,15 \pm 0,02$ & $0,15 \pm 0,02$ & $0,14 \pm 0.02$ & $0.12 \pm 0.03$ & $0,139 b c$ \\
\hline $40-50$ & $0,10 \pm 0,04$ & $0,11 \pm 0,02$ & $0,11 \pm 0,01$ & $0,12=0,02$ & $0,10=0,02$ & $0,12 \pm 0.03$ & $0,111 \mathrm{~cd}$ \\
\hline $50-60$ & $0,06 \pm 0,02$ & $0,09 \pm 0,01$ & $0,09 \pm 0,01$ & $0,11 \pm 0,01$ & $0,08=0,01$ & $0.08 \pm 0.04$ & $0,083 \mathrm{~d}$ \\
\hline Total & $0,85 \mathrm{~A}$ & $0,98 \mathrm{~A}$ & $0,95 \mathrm{~A}$ & $1.07 \mathrm{~A}$ & $0.92 \mathrm{~A}$ & $1.02 \mathrm{~A}$ & - \\
\hline
\end{tabular}

CV\% para tratamento $=31,9 \%$ e CV\% para profundidade $=48.6 \%$

Médias seguidas pelas mesmas letras minusculas nas colunas e maiúculas nas linhas nào diferem entre si pelo teste de Duncan a 5\%. 
Segundo Russell (1981), isso se deve à estrutura de desenvolvimento dos sistemas radiculares. As ramificações laterais, desenvolvidas a partir da raiz principal, têm um crescimento no sentido horizontal por um determinado periodo e, posteriormente, no sentido vertical. Em estudos recentes, Hencklain et al. (1996) constataram enraizamento superificial sob preparo convencional (arado e grade de discos). Embora haja uma correlação estreita entre o enraizamento e o tipo de preparo de solo, esta nem sempre está associada aos rendimentos obtidos, devido particularmente às condições climáticas (Silva et al., 1997). A mesma tendência foi observada em outras culturas, conforme Pedó (1986), Sakai (1996) e em literatura apresentada por Mello (1991).

Mello (1991) observou uma maior concentração de raizes de milho ate os $20 \mathrm{~cm}$ do perfil do solo, em solo PVE, sob preparo convencional. Segundo a autora, com a utilização de implementos agricolas há arranjos estruturais do tipo L e UF (torrões do solo individualizados, estando respectivamente, livres ou unidos/facilmente discerniveis) e melhor distribuição dos nutrientes nessa profundidade. Tais arranjos apresentam maior quantidade de poros grandes e planos de fraqueza entre os elementos estruturais, sendo estes vias preferenciais ao crescimento das raizes por sua menor resistència, o que explica, juntamente com os nutrientes, a maior quantidade de raizes nessa camada.

Os valores de densidade de comprimento de raizes, obtidos durante os três anos no presente trabalho (tabela 16), foram inferiores aos observados em feijoeiro, por Guimarães et al. (1997b), a partir de amostras coletadas por trado nas profundidades desde $0-20 \mathrm{~cm}$ até $100-120 \mathrm{~cm}$ de profundidade. em latossolo vermelho escuro distrófico

Em estudos com outras culturas leguminosas foram relatados valores superiores, sobretudo nas camadas superficiais, quando a amostragem foi feita por outros métodos. Assim foi para a cultura da soja (Bohm et al. 1977. Hulugalle \& Lal, 1986. Pandey et al., 1984; Raper \& Barber, 1970; Sanders \& Brown 1978); do lablabe (Pedo. 1986); do amendoim (Pandey et al., 1984; Zhang et al.. 1993); do caupi (Hulugale \& Lal, 1986; Pandey et al., 1984; Pedó, 1986) e do mungo (Pandey et al., 1984).

Em 1993, observaram-se diferenças significativas entre os valores de densidade de comprimento de raizes dos tratamentos e das profundidades, mas não houve efeito da interação tratamento $x$ profundidade (tabela 16 ). No tratamento em que o 
feijoeiro foi antecedido pela mucuna preta, o valor total foi o menor, sendo significativamente inferior aos demais tratamentos. Este fato ocorrido no primeiro ano das rotações vem corroborar os resultados de Abboud \& Duque (1986), que observaram um efeito alelopático aparente de plantas de mucuna preta sobre as de feijoeiro.

Os valores da camada de $0-10 \mathrm{~cm}$ diferiram significativamente daqueles das demais profundidades, sendo que, de $20 \mathrm{~cm}$ a $50 \mathrm{~cm}$ e de $30 \mathrm{~cm}$ a $60 \mathrm{~cm}$ os valores não diferiram entre si (tabela 16). Em 1994 não houve diferenças significativas entre os tratamentos e nem na interação tratamento $\mathrm{x}$ profundidade mas apenas entre as profundidades. $\mathrm{O}$ valor médio da camada de $0-10 \mathrm{~cm}$ (maior valor) diferiu acentuada e significativamente daquele observado nas demais profundidades, sendo cerca de $70 \%$ superior em relação já à camada seguinte a $10-20 \mathrm{~cm}$. Apenas os valores das camadas de $40-50 \mathrm{~cm}$ e 50-60 cm não diferiram estatisticamente entre si (tabela 16).

Em 1995, à semelhança do observado em 1994, não houve diferenças entre tratamentos em uma mesma profundidade e nem efeito da interação tratamento $x$ profundidade, mas sim entre profundidades. $O$ valor na camada de $0-10 \mathrm{~cm}$ foi maior $\mathrm{e}$ significativamente diferente dos demais, enquanto que os valores das camadas de 10-20 $\mathrm{cm}$ até $30-40 \mathrm{~cm}$; de $20-30 \mathrm{~cm}$ até $40-50 \mathrm{~cm}$ e de $40-50 \mathrm{~cm}$ ate $50-60 \mathrm{~cm}$ não diferiram entre si, respectivamente. A partir de 1994, não se verificou mais qualquer possivel efeito alelopático da mucuna preta sobre o desenvolvimento radicular do feijoeiro.

Em relação aos três anos de avaliação do experimento, tanto os valores individuais por profundidade, quanto os totais para cada tratamento foram maiores em 1994, seguidos pelos de 1995 e 1993, nessa ordem. Inclusive. os valores totais em 1994 foram cerca de duas vezes e meia maiores, em média em relação ao ano anterior. Como em 1994 a precipitação pluvial foi bem inferior e o fornecimento de agua ao feijoeiro deuse, sobretudo, por aspersão com base no monitoramento com tensiòmetro, houve um maior controle em função da necesssidade das plantas. Certamente as condiçôes de umidade do solo foram mais favoráveis ao enraizamento. em termos quantitativos.

Como efeito das proprias rotações, ao longo dos anos. nào houve um tratamento em particular que favorecesse uma maior densidade total de comprimento das raizes do feijoeiro até a profundidade de $60 \mathrm{~cm}$. embora Sfryasaka et al. (1966d) tenham 
observado uma maior quantidade de raizes de feijoeiro cultivado apos leguminosas em relação às gramineas, até $20 \mathrm{~cm}$ de profundidade, em seus estudos de incorporação de matéria orgânica em esquema de sucessão de culturas. Entretanto. ao final do presente estudo, apesar dos valores de todos os tratamentos não serem significativamente diferentes entre si, os maiores resultados foram observados sobretudo nos tratamentos com crotalária júncea, mucuna preta e milho, em relação ao pousio (tabela 16). Coincidentemente, a fitomassa produzida por essas especies foi sempre superior aos demais tratamentos, quando comparada à da vegetação espontànea no pousio (tabela 4).

Neste estudo os valores dos coeficientes de variação foram altos, particularmente entre as profundidades amostradas (tabela 16), como era de se esperar em função da própria morfologia do sistema radicular do feijoeiro. Segundo Guimaràes et al. (1997b), um dos problemas do método de coleta de raizes por meio do trado é a sua grande variabilidade espacial, resultando em coeficientes de variaçào bastante altos entre as repetições. No presente estudo percebe-se a faixa de variação dos erros padrões devida à esse problema (tabela 16).

A distribuição percentual média das raizes do feijoeiro nos tratamentos, nas camadas ao longo do perfil do solo e nos três anos da avaliaçào, esta apresentada nas figuras 4,5 e 6 . Em 1993, essa distribuição foi mais homogènea ate os $20 \mathrm{~cm}$ em todos os tratamentos, à exceção do tratamento com milho, em que ocorreram. inclusive. valores maiores nas profundidades de $40-50 \mathrm{~cm}$ e $50-60 \mathrm{~cm}$ em relaçào a camada de $30-40 \mathrm{~cm}$. indicando uma condição fisica de solo benéfica ao desenvolvimento radicular do feịoeiro. em profundidade, após dois cultivos sucessivos com milho (figura 4)

Em 1994, houve maior concentraçào a $0-10 \mathrm{~cm}$ e ate $20 \mathrm{~cm}$, respectivamente, nos tratamentos com mucuna preta e guandu. enquanto que nos demais tratamentos, em média, essa distribuição percentual foi um pouco mais homogènea ate os $40 \mathrm{~cm}$ (figura 5). Em 1995, embora houvesse uma maior concentração de raizes finas a 0$10 \mathrm{~cm}$ de profundidade nos tratamentos com milho, aveia preta crotalaria juncea e guandu e até nos $20 \mathrm{~cm}$ nos tratamentos em pousio e com mucuna preta. a partir dessas camadas houve uma distribuição mais equilibrada ate os 30 a $40 \mathrm{~cm}$ de profundidade em todos os tratamentos (figura 6) 

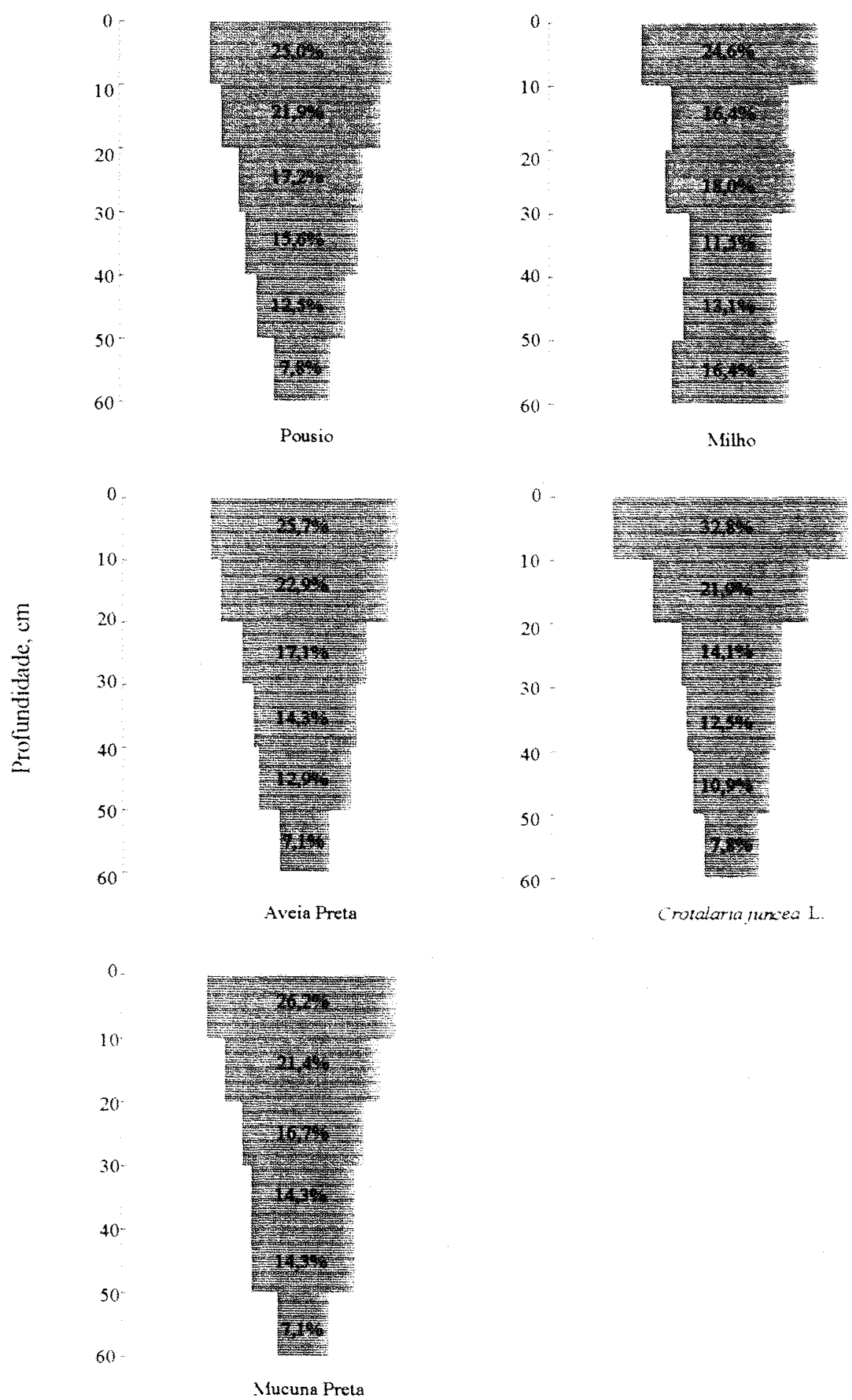

Figura 4: Distribuição percentual média do sistema radicular do feijoeiro, no estádio R7, em diferentes profundidades, após rotação com culturas graniferas e adubos verdes. Ríbeirão Preto. SP. 1993. 

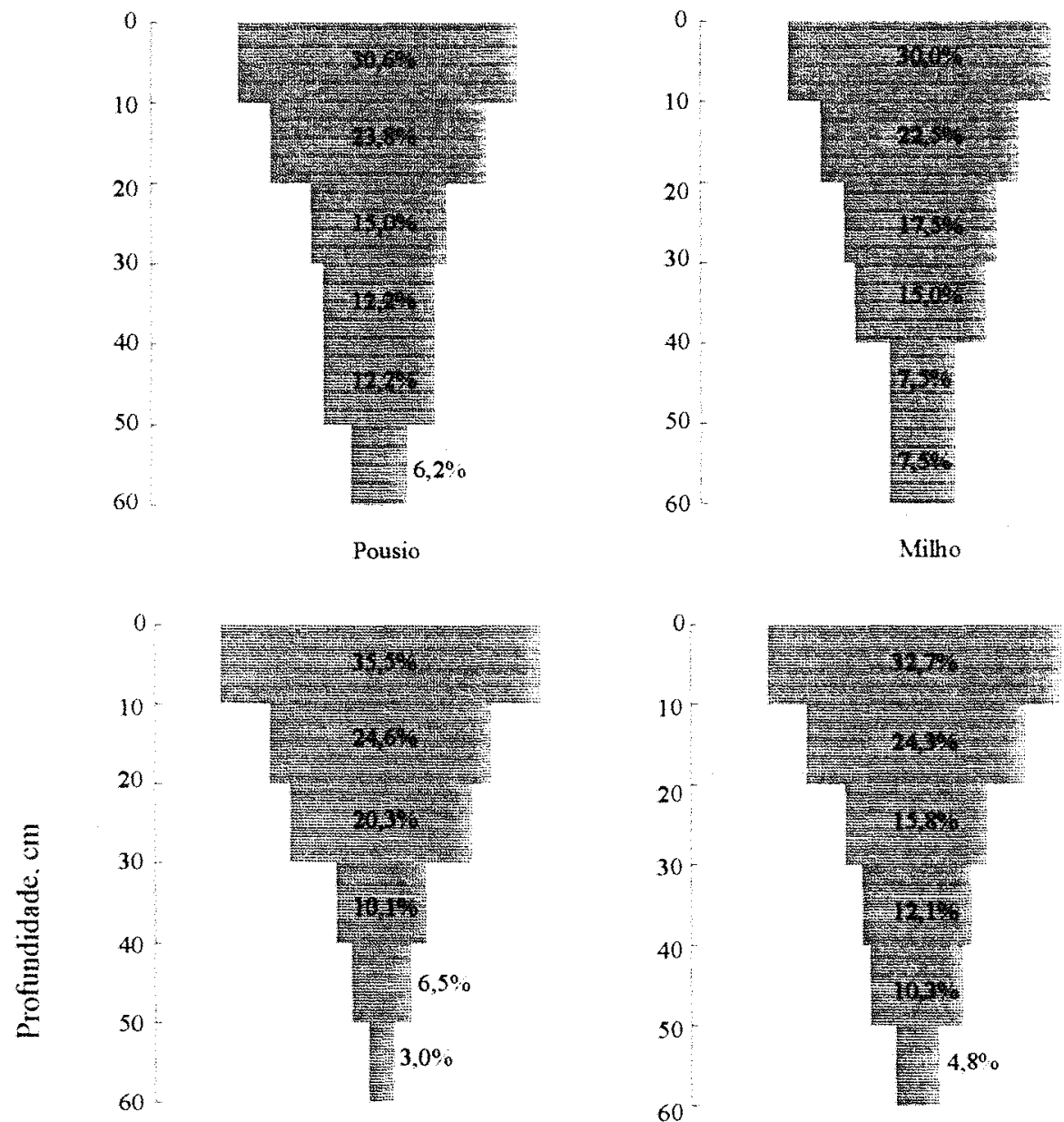

Aveia Preta

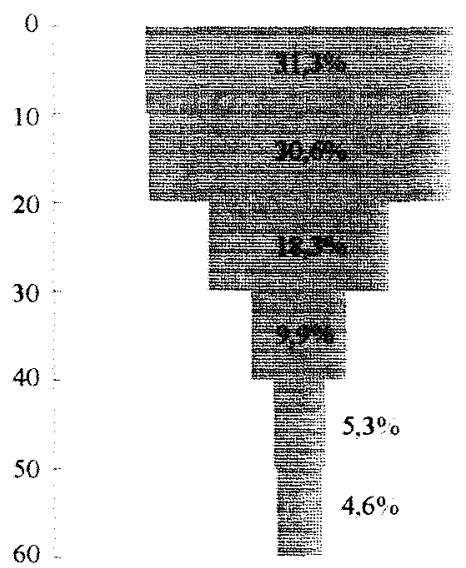

Guandu

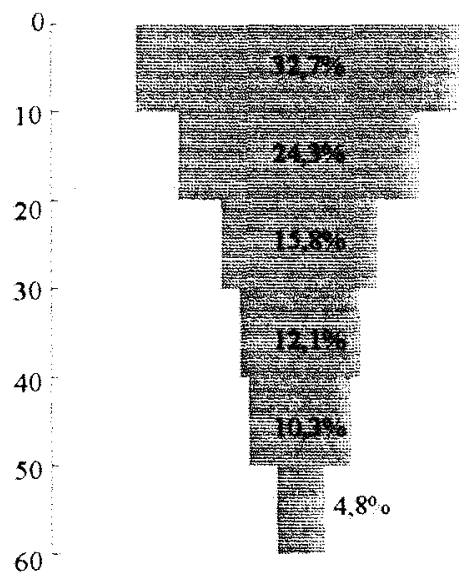

Crotalaria uncea L.

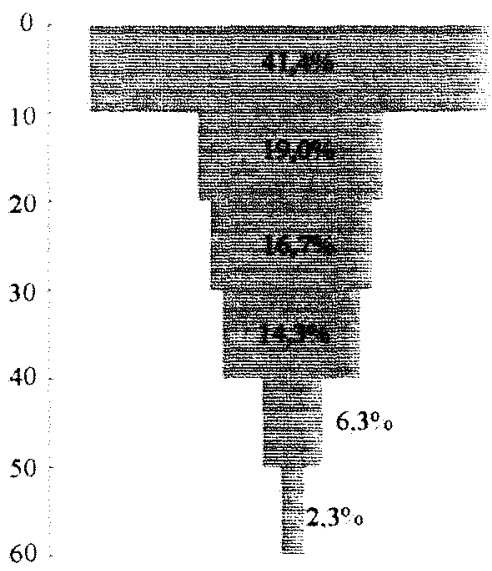

Nucuna Preta

Figura 5: Distribuição percentual média do sistema radicular do feijoeiro, no estádio $\mathrm{R} 7$, em diferentes profundidades, após rotação com culturas graniferas e adubos verdes. Ribeirão Preto, SP, 1994. 


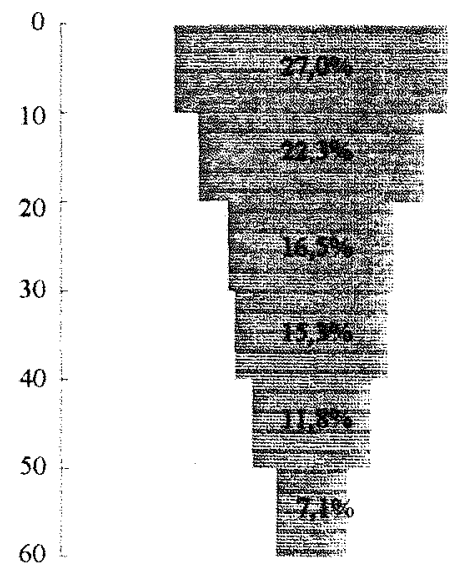

Pousio

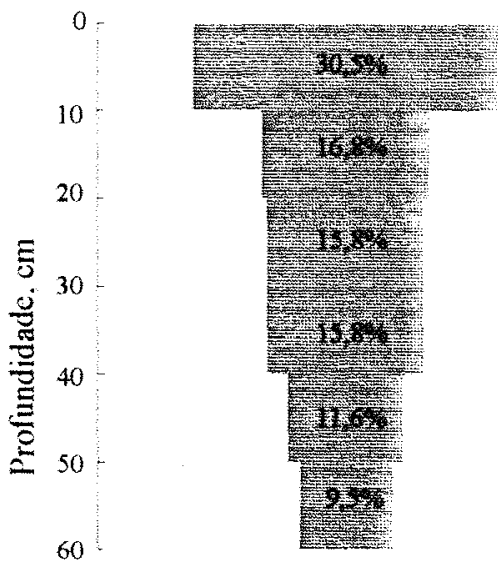

Aveia Preta

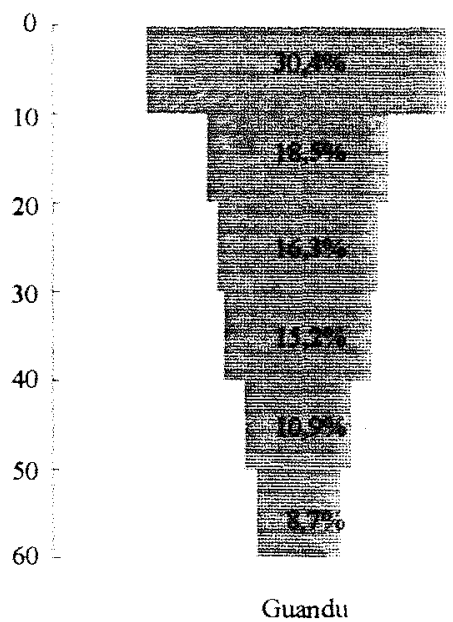

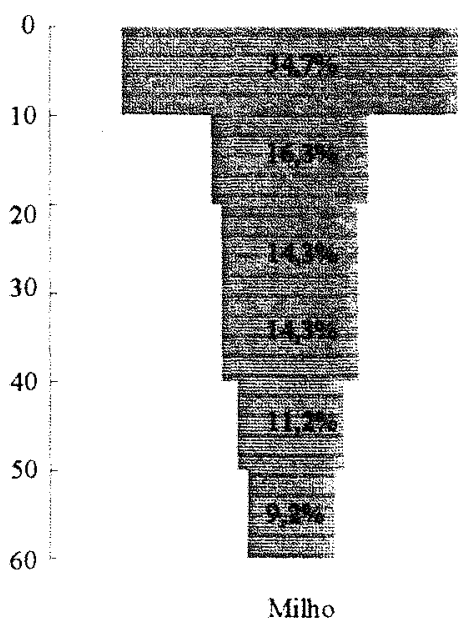
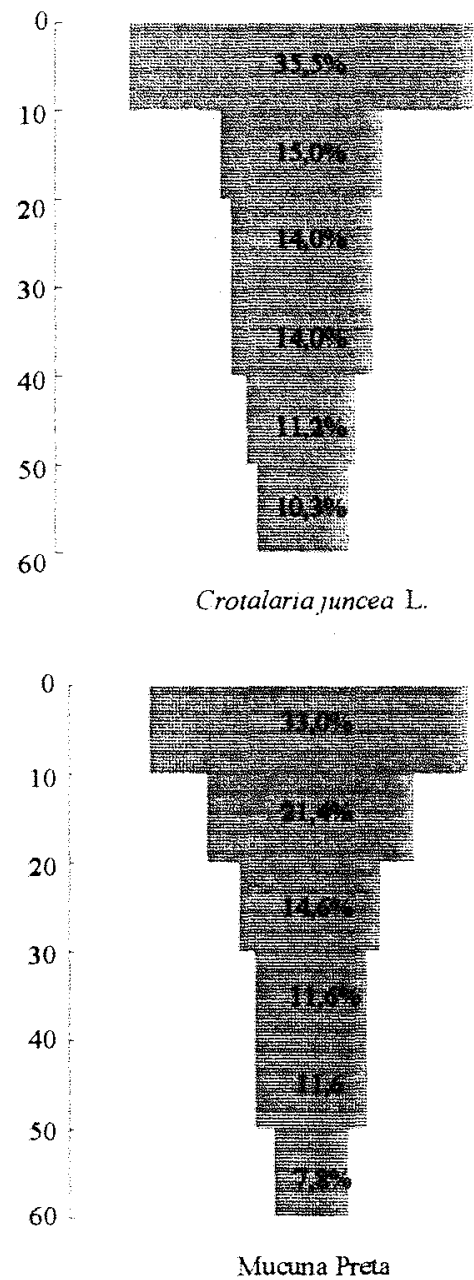

Figura 6: Distribuição percentual média do sistema radicular do feijoeiro, no estádio R7, em diferentes profundidades, após rotação com culturas graníferas e adubos verdes. Ribeirão Preto, SP, 1995. 
Os valores totais de densidade de comprimento de raizes correlacionaramse linear e significativamente em 1994 com a quantidade de matéria seca da parte aérea e com o IAF. Embora não tivessem sido significativas em 1995, essas correlações aproximaram-se do nível de significância (tabela 20)

Esta tendência está de acordo com a afirmações de Avilan-Rovira (1975); Osaki et al. (1997); Russell (1961) e Tanaka \& Fujita (1979). segundo as quais, o crescimento da parte aérea e do sistema radicular é estreitamente integrado. Essa relação, entretanto, pode ser bastante variável, em função das condiçôes do meio e do estado fisiológico das plantas.

Osaki et al. (1997) afirmam que, em culturas de leguminosas e de gramíneas, não só o tipo mas também o dossel e suas estruturas tèm uma importante função na manutenção de uma alta atividade radicular.Tanaka \& Fujita (1979) observaram que, em feijoeiro, a principal fonte de fotossintetizados para as raizes são principalmente as folhas do terço inferior da planta.

Nos estudos de Humphries $(1962,1967)$ houve uma relaçào de controle da taxa de de crescimento radicular do feijoeiro, cultivar "Canadian Winter", sobre a taxa de movimentação de fotossintetizados da lâmina foliar. Assim. com um crescimento radicular mais lento havia um aumento no teor de açucares e amidos na làmina e quando aquele era mais rápido, havia uma redução no teor de carboidratos desta e um aumento na taxa de assimilação liquida. Em amendoim, de acordo com alguns autores mencionados em Zhang et al. (1993), também se observou uma forte correlaçào positiva entre o crescimento das partes aérea e radicular de suas plantas

A tendência observada no presente estudo e na literatura mencionada anteriormente é discordante de Bohm (1977) e de Bulisani et al. (1987). Segundo estes últimos autores, "como fator inerente ao feijoeiro, especialmente em plantas dos tipos I, II e III, há uma inabilidade de translocação de carboidratos ao sistema radicular. relacionada à maior competitividade da parte aérea em relaçào às raizes por fotossintetizados" (Bulisani et al.,1987).

Possivelmente, por haver, em geral, condiçòes de fertilidade do solo similares entre os tratamentos (tabelas 6,7 e 8), não se verificou essa competitividade, 
conforme relatado por Avilan-Rovira (1975), em feijoeiro adubado em relaçâo ao não adubado. Nesse caso, observou-se maior redução no peso da parte aérea das plantas não adubadas, enquanto que a diferença no peso radicular não foi tão acentuada. Isso porque, as condições ecológicas a campo podem alterar a relação parte aérea/raizes.

A tendência de distribuição de raizes observada ao longo do perfil, de modo geral está associada aos valores de densidade de solo (tabela 9) e de RP (figuras 1 , 2 e 3).

Nos primeiros estudos clássicos, Veihmeyer \& Hendrickson (1948) já relatavam uma diminuição do crescimento radicular com o aumento dos valores de densidade do solo, entretanto, não discutiram a possivel influència de varios outros fatores agregados.

Embora não tenham sido observadas diferenças estatisticas ente os valores de densidade no presente trabalho, houve, em média, um aumento de $1.33 \mathrm{~g} / \mathrm{cm}^{3}$ na camada de 0-20 cm para $1,37 \mathrm{~g} / \mathrm{cm}^{3}$ na camada de $20-40 \mathrm{~cm}$ (tabela 9). Em relação aos valores de RP, observou-se uma camada mais adensada a $15-30 \mathrm{~cm}$ a $30-40 \mathrm{~cm}$ e a $25-$ $35 \mathrm{~cm}$ de profundidade, respectivamente, em 1993, 1994 e 1995 (figuras 1. 2 e 3). Isso pode ter colaborado para a redução, ainda que pequena. do desenvolvimento das raizes. já que os resultados das análises granulométrica (tabela 2) e quimica (tabelas 6,7 e 8) não indicaram uma possivel restrição ao desenvolvimento radicular. Inclusive. os teores de cálcio, elemento esse que é reconhecidamente promotor do crescimento radicular, foram sempre altos e adequados (tabelas 6,7 e 8), concordando com Goedert et al. (1985) e Ritchey et al. (1983). Segundo esses autores, o crescimento das raizes de culturas anuais está estreitamente relacionado ao nivel de cálcio disponivel no perfil do solo.

Ainda assim, entretanto, observou-se no presente trabalho, um desenvolvimento radicular abaixo desta camada mais adensada o que pode estar associado a uma condição de boa disponibilidade de água, uma vez que a cultura do feijoeiro foi irrigada sempre que necessário. Segundo Castro (1994). a presença de agua no perfil do solo reduz a resistência à penetração e a penetração das raizes em estruturas compactadas é facilitada (Guimarães et al., 1997a) 
Também, já se observou aumento da eficiència radicular do feijoeiro, cultivar Carioca, na absorção de água em profundidade, independentemente, inclusive, do nivel de deficiência hídrica (Guimarães et al., 1996), provavelmente devido à maior concentração de raízes novas nas camadas mais úmidas e profundas (Stone et al., 1976). Supõe-se que a área superficial e a atividade fisiológica sejam altas nessas camadas, onde a quantidade de raizes, em relação ao total, é menor (Follett et al., 1974).

Ainda, os valores de $\mathrm{pH}$ foram crescentes em profundidade em todos os anos e tratamentos observados, o que possibilitou a manutenção de condições ainda algo favoráveis ao enraizamento no subsolo, concordando com os resultados de Pearson (1971). Esse autor observou cerca de $22 \%$ do total de raizes de milho a $45-60 \mathrm{~cm}$ de profundidade, sob condições de subsolo moderadamente ácido e restrição do crescimento radicular dessa gramínea a $30 \mathrm{~cm}$ de profundidade quando as condiçōes do subsolo eram de acidez forte.

Mesmo diante de uma situação evidente de deficiència nutricional em fósforo nas plantas de feijoeiro, constatada na análise foliar (tabela 11), os teores desse elemento no solo foram considerados normais (tabelas 6,7 e 8). Isso nào pareceu afetar o desenvolvimento radicular dessa leguminosa, concordando com observaçōes de Malavolta et al. (1980) e de Russell (1961). O sistema radicular de plantas de feijoeiro com deficiência em fósforo aparentemente não difere daquele de plantas sem deficiência. cultivadas em solução nutritiva completa, no mesmo estadio de crescimento (Malavolta et al., 1980). Ainda, em condições de campo, nem sempre todas as partes de um sistema radicular estão expostas ao mesmo grau de compactação. podendo haver um crescimento compensatório destas. A adição continuada de matéria orgânica que pode ser por meio da rotação de culturas com incorporação de residuos vegetais, possibilita a redução da RP de um solo quando compactado.

A medição da RP com penetròmetro é auviliar na avaliação da resistência que o solo oferece ao desenvolvimento da raiz. Entretanto. com a decomposiçào de outras raizes e de material orgânico fresco, verifica-se que pode ocorrer uma orientação do crescimento radicular para pontos de menor resistència do solo. Apesar disso. essa medição se correlaciona bem com o desenvolvimento radicular (Taylor. 1974). 
Assim é que, em plântulas de feijoeiro, Schumacher \& Smucker (1981) relataram um aumento dos valores da relação parte aérea/sistema radicular com os aumentos respectivos dos valores de RP. Essa tendência também foi observada em estudos de modelo simulado com milho (Grant, 1993).

\subsubsection{Profundidade efetiva}

Analisando-se os resultados para fins de manejo de irrigaçào do feijoeiro, nesse tipo de solo, nos três anos da experimentação, parece ser adequado considerar a profundidade efetiva do sistema radicular como sendo de 35 a $40 \mathrm{~cm}$. onde se concentram mais de $80 \%$ das raizes finas (tabela 17).

A partir dessa profundidade ocorre uma redução acentuada na distribuição percentual das raizes. Esses resultados são muito próximos daquele obtido por Pires et al. (1991), em que a profundidade efetiva onde se concentraram mais de $80^{\circ} \%$ de raizes finas de feijoeiro, cultivar Carioca-80, irrigado, foi de $30 \mathrm{~cm}$. Estes autores tambem utilizaram o método do trado na coleta de amostras em um podzólico vermelho-amarelo latossólico eutrófico, em Votuporanga, SP.

São superiores, entretanto, em relaçào àqueles primeiramente relatados em feijoeiro, em condiçôes de sequeiro, por Inforzatto \& Mivasaka (1963), segundo os quais, cerca de $84 \%$ e $97 \%$ das raizes concentraram-se a $20 \mathrm{~cm}$ de profundidade. respectivamente, em podzólico vermelho-amarelo de Monte Alegre do Sul e em um podzolizado de Lins e Marilia, em Pindorama, SP.

Diferem também dos de Avilan-Rovira (1975) que, pelo método do monolito, relatou a acorrência de $95 \%$ do peso total do sistema radicular do feijoeiro. cultivar Carioca, nos primeiros $30 \mathrm{~cm}$ de profundidade de um solo terra roxa estruturada; máxima atividade de raizes nos primeiros $10 \mathrm{~cm}$ do solo, pelo metodo do elemento marcado e $91,4 \%$ do peso total radicular a $0-15 \mathrm{~cm}$ pelo metodo da sonda. Sào distintos também daqueles obtidos por Caixeta et al. (1983). 
Tabela 17: Profundidade efetiva ( $80 \%$ ) do sistema radicular do feijoeiro irrigado, em $\mathrm{cm}$, em latossolo roxo, após rotação com culturas graniferas e adubos verdes. Ribeirão Preto, SP, 1993 a 1995.

\begin{tabular}{|c|c|c|c|c|c|c|}
\hline \multirow{2}{*}{$\begin{array}{c}\text { Ano } \\
\text { agrícola }\end{array}$} & \multicolumn{6}{|c|}{ Cultura anterior ao feijoeiro } \\
\hline & Pousio & Milho & $\begin{array}{l}\text { Aveia } \\
\text { preta }\end{array}$ & $\begin{array}{c}\text { Crotalaria } \\
\text { juncea }\end{array}$ & Guandu & $\begin{array}{c}\text { Mucuna } \\
\text { preta }\end{array}$ \\
\hline & \multicolumn{6}{|c|}{$\mathrm{cm}$} \\
\hline 1993 & 40,2 & 47,3 & 40,0 & 39,0 & $-\ldots-.-$ & 41,0 \\
\hline 1994 & 38,7 & 36,7 & 29,8 & 36,0 & 29,9 & 32.0 \\
\hline 1995 & 39,3 & 40,4 & 41,0 & 41.0 & 39.7 & 39.5 \\
\hline Média & 39,4 & 41,5 & 36,9 & 38.7 & 34.8 & 37,3 \\
\hline
\end{tabular}

Essas diferenças, à exceção do observado por Pires et al. (1991), podem ser atribuídas à metodologia adotada, uma vez que no presente trabalho as amostras de solo com raizes foram coletadas com trado tipo caneca. sendo consideradas apenas as raizes finas na determinação de sua densidade de comprimento. No trabalho de Inforzatto \& Miyasaka (1963), não há qualquer informação sobre o nivel de fertilidade do solo ou de suas características fisicas. Além disso, a determinação da distribuição de raizes por peso, conforme adotada nos demais estudos, pode não ser o ideal do ponto de vista fisiológico da absorção, segundo observações de Franco \& Inforzatto (1946).

A dificuldade na medição da distribuição das raizes ativas ou finas no solo. por sua vez, é um dos obstáculos nos estudos dos sistemas radiculares em condições de campo. A escolha pela determinação de raizes com diàmetro inferior a $1 \mathrm{~mm}$ não deixa de ser um parâmetro arbitrário, também adotado por outros autores em seus estudos com o feijoeiro (Pires et al., 1991) ou com o milho (Sakai, 1996).

Uma vez que a ênfase no presente trabalho foi o desenvolvimento radicular do feijoeiro relacionado ao favorecimento da absorção de agua e de nutrientes e sua consequiente relação com o rendimento em grãos. decidiu-se considerar apenas as raizes finas, ou absorventes. Estas raizes finas, segundo Portas (1970). tèm diâmetro inferior a pelo menos $1 \mathrm{~mm}$, são abundantemente dotadas de pelos radiculares e sua função principal consiste na absorção de água e de nutrientes. alem de serem uma superficie de ativa troca iônica. 


\subsection{Estande de plantas}

Os resultados do estande final para o feijoeiro, nos diferentes tratamentos e anos, estão relacionados na tabela 18 .

Não se observaram diferenças significativas entre os tratamentos em cada ano; entre anos e nem na interação tratamento $\mathrm{x}$ ano, possibilitando efetuar as comparações entre os dados de rendimento em grãos por ano, uma vez que estão sendo consideradas populações de plantas semelhantes.

Em média, os estandes variaram de $192,9 \mathrm{mil}$ para $201,7 \mathrm{mil}$ e de 195,0 mil para 203,0 mil plantas/hectare, respectivamente para os tratamentos e anos. Dessa maneira, estiveram ao redor de $200 \mathrm{mil}$ plantas/hectare. concordando com a faixa de variação correspondente a 200 - $375 \mathrm{mil}$ plantas/hectare. relatada na literatura nacional (Bulisani \& Almeida, 1986; Bulisani et al, 1987; Chagas, 1988: Silva. 1996; Vieira. 1978).

Nas condições paulistas, em que a cultura do feijoeiro e desenvolvida de forma exclusiva, são adequadas as populações entre 150 e $200 \mathrm{mil}$ plantas/hectare, distribuídas em linhas espaçadas 50 a $60 \mathrm{~cm}$ entre si, com 10-12 plantas por metro linear. Em estudos realizados de 1978 a 1980 no IAC, em Campinas. SP. verificou-se garantia de manutenção do mesmo nivel de produtividade e maior facilidade nas operações de capinas e de tratos culturais no espaçamento de $60 \mathrm{~cm}$ (Bulisani et al. 1987).

Conforme orientação de Stone \& Sartorato (1994). também são recomendadas as populações entre 200 a 240 mil plantas hectare na cultura exclusiva do feijoeiro, com ressalva apenas para o uso do espaçamento de $50 \mathrm{~cm}$ entrelinhas.

Guidolin et al. (1996) verificaram uma diminuição no rendimento do cultivar IAC-Carioca (tipo III) com o aumento da população de $200 \mathrm{mil}$ para $400 \mathrm{mil}$ plantas/hectare. Segundo os autores, teria ocorrido uma competiça intragenotipica entre as plantas prostradas, do tipo III, quando comparadas com aquelas eretas e de menor porte do tipo II. Isso, entretanto, é contrário às observações de Salgado et al. (1992), citados em Silva (1996). 
Tabela 18: Estande de plantas de feijoeiro, cultivar IAC-Carioca, no estádio R9 em rotação com milho/culturas graniferas e adubos verdes. Ribeirão Preto, São Paulo, 1993, 1994 e 1995.

\begin{tabular}{|c|c|c|c|c|}
\hline $\begin{array}{c}\text { Cultura anterior ao } \\
\text { feijoeiro }\end{array}$ & 1993 & 1994 & 1995 & Média \\
\hline & \multicolumn{4}{|c|}{-... mil plantas/hectare } \\
\hline Pousio & 188,7 & 199,2 & 190,9 & $192,9 \mathrm{a}$ \\
\hline Milho & 193,3 & 194,2 & 197,6 & $195,1 \mathrm{a}$ \\
\hline Aveia preta & 200,2 & 204,4 & 192,4 & $199,0 \mathrm{a}$ \\
\hline Crotalaria juncea L. & 199,8 & 209,2 & 195,9 & $201,7 \mathrm{a}$ \\
\hline Guandu & 197,0 & 207,8 & 195.8 & $200,2 \mathrm{a}$ \\
\hline Mucuna preta & 198,6 & 202.8 & 197.6 & $199,7 \mathrm{a}$ \\
\hline Média & $196,2 \mathrm{~A}$ & $203,0 \mathrm{~A}$ & $195.0 \mathrm{~A}$ & - \\
\hline $\mathrm{CV}(\%)$ & \multicolumn{4}{|c|}{$6,2-\square$} \\
\hline
\end{tabular}

Médias seguidas pelas mesmas letras minúsculas nas colunas e maiusculas nas línhas nào diferem entre si pelo teste de Duncan a $5 \%$.

Em geral, tem-se observado grande capacidade de compensação no cultivar Carioca sob diferentes densidades populacionais, havendo bons rendimentos mesmo nos menores estandes, devido, sobretudo, ao aumento do numero de vagens por planta (Arf et al., 1990; Del Peloso, 1990 e Silveira et al. 1990; todos citados em Silva, 1994; Stone \& Pereira, 1994).

Também, há aumento do IAF em função da densidade de semeadura e. portanto, pode-se esperar maior produtividade sob densidades maiores (Brandes et al.. 1973; Tanaka \& Fujita, 1979).

No presente estudo, coincidentemente aos maiores valores de IAF (tabela 14), na maioria das vezes corresponderam os maiores valores individuais de população de plantas por área (tabela 18). 


\subsection{Rendimento de grãos}

Os resultados de rendimento de grãos de feijoeiro nos anos de 1992 a 1995 estão relacionados na tabela 19. Não houve diferenças significativas entre os anos e, como a interação tratamento $\mathrm{x}$ ano também não foi significativa, os resultados podem ser considerados similares, independente do ano avaliado. Entretanto, os tratamentos, em média, difereriram estatisticamente entre si.

Os valores de rendimento obtidos no presente estudo, particularmente naqueles tratamentos com mucuna preta e crotalária juncea, em 1994 e 1995 e até mesmo a média obtida em 1994 foram similares aos obtidos em experimentaçào com o feijoeiro irrigado por Carvalho et al. (1996); Magalhães \& Millar (1978), Pires et al. (1991) e por Silveira et al. (1984).

Estão de acordo com o nivel médio de produtividade de $2.000 \mathrm{~kg} / \mathrm{ha}$, previsto para a safra de "inverno", na mesma região em que foi desenvolvido este estudo, estabelecido no zoneamento ecológico e épocas de semadura para o feịoeiro no Estado de São Paulo (Pinzan et al., 1994).

Tabela 19: Rendimento de grãos de feijoeiro. cultivar LAC-Carioca. em rotação com milho/culturas graniferas e adubos verdes. Ribeirão Preto. São Paulo 1992 a 1995

\begin{tabular}{|c|c|c|c|c|c|}
\hline Cultura anterior & 1992 & 1993 & 1994 & 1995 & Média \\
\hline & & & $-\mathrm{kg} / \mathrm{ha}$ & & \\
\hline Pousio & -..-- & 1.820 & 1.792 & 1.751 & $1.788 \mathrm{bc}$ \\
\hline Milho & $\cdots$ & 1.706 & 2.009 & 1.760 & $1.826 \mathrm{abc}$ \\
\hline Aveia preta & $-\cdots$ & 1.578 & 1.409 & 1.748 & $1.578 \mathrm{c}$ \\
\hline Crotalaria juncea $\mathrm{L}$. & 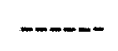 & 1.798 & 2.191 & 2.133 & $2.041 \mathrm{ab}$ \\
\hline Guandu & -.--- & 1.608 & 1.914 & 1.496 & $1.672 \mathrm{c}$ \\
\hline Mucuna preta & $\cdots$ & 1.742 & 2.248 & 2.204 & $2.064 \mathrm{a}$ \\
\hline Média & 2.873 & $1.709 \mathrm{~A}$ & $1.927 \mathrm{~A}$ & $1.849 \mathrm{~A}$ & \\
\hline CV (\%) & & 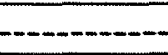 & -20.4 & $=$ & \\
\hline
\end{tabular}

Médias seguidas pelas mesmas letras minúsculas nas colunas e maiusculas nas linhas nào diferem entre si pelo teste de Duncan a $5 \%$. 
Esses resultados assemelham-se tambèm, à média obtida em Goiás (2.105 $\mathrm{kg} / \mathrm{ha}$ ), um dos maiores estados produtores de feijoeiro na safra de 1995 (FIBGE, 19901996) e aos valores médios obtidos com o cultivar IAC-Carioca. em ensaios para fins de recomendação de cultivares desenvolvidos pelo Instituto Agronòmico de Campinas (IAC), Instituto Biológico (IB) e Coordenadoria de Assistència Técnica Integral (C.A.T.I.), tanto na média da safra "de inverno" com irrigação, de 1993 a 1997 (maio/junho a setembro/outubro) $(2.088 \mathrm{~kg} / \mathrm{ha})$, quanto na media para o município de Ribeirão Preto, nessa mesma safra e periodo (2.039 kg/ha) (Wutke. 1997)

Foram sobretudo superiores aos valores medios de produtividade nacional da safra "de inverno", com irrigação, no periodo 1990-1994 (1.225 kg/ha); à média das regiōes sul, sudeste e centro-oeste em 1994 (1.308 kg/ha) (Yokoyama et al., 1996). e ainda, à média obtida para o cultivar IAC-Carioca irrigado. no Estado de São Paulo, nos ensaios acima mencionados, na safra "das águas", de 90/91 a 95/96 (1.582 kg/ha) (Wutke, 1997) ${ }^{8}$.

$\mathrm{Na}$ média dos tratamentos, ao longo dos très anos do experimento. e como efeito das próprias rotações em relação ao pousio, destacou-se. estatisticamente, o resultado do tratamento com a mucuna preta. Este nào diferiu significativamente apenas dos tratamentos com a crotalária júncea e o milho, também cultivados no periodo não convencional de outono-inverno, sendo possivel obter ganhos de rendimento de $15.4 \%$ : $14,1 \%$ e $2,1 \%$, respectivamente.

Essa situação de destaque do tratamento com a mucuna preta é concordante com os resultados dos estudos de Arf et al. (1996). Estes autores obtiveram valores de rendimento do feijoeiro irrigado, no inverno. muito similares aos obtidos no presente estudo, particularmente quando a mucuna preta foi semeada em associação, aos 100 dias após a semeadura do milho $(1.981 \mathrm{~kg} / \mathrm{ha})$, porem, valores superiores quando essa leguminosa adubo verde foi cultivada de forma exclusiva antes do feijoeiro (2.407 $\mathrm{kg} / \mathrm{ha}$ ), correspondendo a um aumento de de $21,5 \%$ em relação à primeira situaçào.

Chagas et al. (1993) obtiveram aumento de $39.2 \%$ no rendimento do feijoeiro irrigado e cultivado após a mucuna preta.

\footnotetext{
${ }^{8}$ Wutke. E.B. Relatório individual sobre experimentação com o feijoeiro. Seça de Leguminosas. IAC. 1997.
} 
Isso vem confirmar a tendência de obtenção de resultados benéficos da adubação verde sobre o rendimento do feijoeiro relatados na literatura, ainda que no período de verão (Almeida et al., 1971; Arf et al., 1996; Bulisani et al., 1987; Chagas et al., 1993; Mascarenhas et al., 1967a,b; Merola et al., 1997; Miyasaka et al., 1966a,d; Silva et al., 1996; Silveira \& Silva, 1996; Veiga et al., 1977; Vieira, 1967).

Em termos de qualidade de fitomassa, a incorporação de leguminosas tem sido mais vantajosa ao feijoeiro do que a de gramíneas (Bulisani et al, 1972; Miyasaka et al., 1966a,d; 1967). Além disso, conforme observado por Miyasawa et al. (1993), os efeitos dos resíduos vegetais das leguminosas na melhoria dos solos ácidos, embora sejam de curta duração, podem ser muito importantes pelo menos na fase inicial da cultura subseqüente. A inclusão de crotalária juncea em estudos sobre eficiência agronômica, econômica e energética de culturas anuais em sucessão como o milho, a soja e o trigo, contribuiu para a sustentabilidade econômica do sistema além de não ter interferido na época preferencial de semeadura daquelas culturas comerciais (Oliveira, 1996).

Apesar de não haver diferenças estatísticas significativas entre os tratamentos com mucuna preta e crotalária júncea e milho, os efeitos dessa gramínea como cultura antecessora no rendimento do feijoeiro foram inferiores aos observados nos tratamentos com as leguminosas (tabela 19). São menores do que os relatados por Silveira \& Silva (1996), que obtiveram rendimentos médios entre $2.046 \mathrm{~kg} / \mathrm{ha}$ e 2.096 $\mathrm{kg} / \mathrm{ha}$ no feijoeiro em sucessão ao milho e entre $2.082 \mathrm{~kg} / \mathrm{ha}$ e $2.757 \mathrm{~kg} / \mathrm{ha}$ no feijoeiro no esquema de rotação milho/feijoeiro/milho/feijoeiro/arroz/feijoeiro.

Cabe lembrar, entretanto, que nesta situação agrícola houve apenas um ciclo de milho no mesmo ano agrícola, enquanto que, em um dos tratamentos do presente estudo, o feijoeiro foi antecedido por duas culturas sucessivas de milho de ciclo precoce.

Os resultados foram porém, superiores ao dados de Chagas et al. (1993), que obtiveram aumento de $10,9 \%$ no rendimento do feijoeiro após a cultura do milho; de Krantz et al. (1996), em cujos estudos observou-se rendimento médio de $1.279 \mathrm{~kg} / \mathrm{ha}$ no feijoeiro "da seca" após milho, em sistema convencional de cultivo e de Santos et al. (1996), com rendimento médio de $1.751 \mathrm{~kg} / \mathrm{ha}$ em feijoeiro, cultivar Carioca, irrigado no inverno, em sucessão ao milho. 
No presente trabalho, os resultados do rendimento de grãos do feijoeiro no tratamento com milho não diferiram significativamente do pousio (tabela 19). A contribuição em fitomassa no pousio, variável em função da vegetação espontânea estabelecida a cada ano, foi muito inferior àquela produzida palas plantas de milho (tabela 4). Entretanto, pode ter ocorrido menor disponibilidade de nitrogênio para o feijoeiro, em função da elevada relação $\mathrm{C} / \mathrm{N}$ que sabidamente a fitomassa de milho apresenta.

Em 1994, os rendimentos do feijoeiro após o milho "safrinha" foram maiores do que nos demais anos para este mesmo tratamento. É que neste ano houve ocorrência de geada, inviabilizando a colheita de grãos do milho e apenas a sua fitomassa foi considerada. Conseqüentemente, os nutrientes que seriam exportados pelos grãos foram aproveitados pela cultura subseqüente, no caso o feijoeiro

Em estudos de viabilidade econômica de sistemas agrícolas irrigados por aspersão nos cerrados, Silva \& Silveira (1996) obtiveram os melhores retornos econômicos quando o feijoeiro e o milho foram componentes do mesmo esquema de rotação de culturas, devido aos níveis de produtividade alcançados e à relação de preços de fatores e produtos à época da análise. Apesar dos custos de produção serem maiores, obteve-se a mais alta liquidez com a cultura da leguminosa.

Em geral, os valores foram inferiores à média observada na própria área experimental, no início desses estudos, em 1992 (2.873 kg/ha)(tabela 19). Esse resultado, inclusive, mostrou-se superior à média obtida com o cultivar IAC-Carioca em ensaios de recomendação de cultivares no Estado de São Paulo, tanto na safra de inverno irrigado estadual, quanto naquela localizada em Ribeirão Preto, de 1993 a 1997 (Wutke, 1997).

Conforme os dados da tabela 3 , verifica-se que a data de semeadura foi sendo deslocada, a cada ano e a partir de 1992, da época preferencial para a região (abril a junho) para épocas consideradas de maiores riscos climáticos para o bom desenvolvimento do feijoeiro, segundo informações compiladas por Pinzan et al. (1994), no documento "Feijão - Zoneamento ecológico e épocas de semeadura para o Estado de São Paulo". Segundo esses autores, para a região próxima ao município de Ribeirão Preto, admitem-se semeaduras de 15 de abril a 30 de junho, com produtividade média esperada ao redor de $2.000 \mathrm{~kg} / \mathrm{ha}$ para a safra "de inverno irrigada" e de 01 de agosto a 
30 de setembro, na safra "das águas", com produtividade variável em função do nível de tecnologia e sob a influência de maiores temperaturas durante o ciclo e ocorrência de chuvas na colheita.

Embora Carvalho et al. (1996) tenham relatados maiores valores médios de rendimentos em quatorze cultivares de feijoeiro irrigado, dentre os quais o IACCarioca, semeados na primeira quinzena de julho $(2.076 \mathrm{~kg} / \mathrm{ha})$ do que na primeira quinzena de maio (1.735 kg/ha), na região de Ilha Solteira, $S P$, observou-se o contrário no presente estudo.

Assim é que os valores médios de rendimentos de grãos foram acentuadamente decrescentes já em 1993, quando a data de semeadura do feijoeiro foi adiada em cerca de dois meses em relação à de 1992 (tabelas 3 e 19). Diante disso e, de acordo com os dados climatológicos coletados no próprio local (tabela 1), nota-se que, durante o ciclo das plantas os valores médios de temperatura foram maiores de 1993 a 1995, o que certamente também contribuiu para a redução nos rendimentos.

Segundo Coyne (1968) e Davis (1966), a temperatura é o fator climático mais relevante sobre a percentagem de pegamento de vagens em feijoeiro. Essa influência é maior sobretudo, por ocasião do aparecimento das primeiras flores, cuja mortalidade é muito alta sob temperaturas elevadas (Smith \& Pryor, 1962). As melhores temperaturas para o desenvolvimento do feijoeiro nas suas fases vegetativa e reprodutiva estão entre $17^{\circ} \mathrm{C}$ e $27^{\circ} \mathrm{C}$ (Pinzan et al., 1994), sendo que Stobbe et al. (1966) relataram anteriormente o termoperíodo ideal em torno de $29,5^{\circ} \mathrm{C} / 21,0^{\circ} \mathrm{C}$ (dia/noite) para garantia de máxima produtividade dessa leguminosa. Também Laing et al. (1983) estabeleceram os valores médios de temperaturas mínima, ótima e máxima como sendo $12^{\circ} \mathrm{C}, 21^{\circ} \mathrm{C} \mathrm{e}$ $29^{\circ} \mathrm{C}$, respectivamente, em avaliação de 250 genótipos de feijoeiro.

No presente estudo e, com base nos dados da tabela 19, calcularam-se reduções de 40,5\%,32,9\% e 35,6\%, respectivamente, em 1993, 1994 e 1995, em relação ao rendimento médio do feijoeiro em 1992. Verificou-se que, na época do florescimento, particularmente nos seus primeiros dias, os valores decendiais das temperaturas máxima e média estiveram, respectivamente, ao redor de $28,4^{\circ} \mathrm{C}$ e $21,9^{\circ} \mathrm{C}$ em $1993,33,0^{\circ} \mathrm{C}$ e $26,2^{\circ} \mathrm{C}$ em 1994 e $28,5^{\circ} \mathrm{C}$ e $23,5^{\circ} \mathrm{C}$ em 1995 (tabela 1). Em 1992, esses valores, 
observados no mesmo estádio fenológico, foram $26,5^{\circ} \mathrm{C}$ e $19,3^{\circ} \mathrm{C}$, configurando, portanto, melhores condicões térmicas para o desenvolvimento do feijoeiro.

Esses resultados estão de acordo com a tendência observada nos estudos de Mack \& Singh (1969), em que se relataram reduções no rendimento de grãos do feijoeiro da ordem de $67 \%$ e $22 \%$ quando as temperaturas médias entre o terceiro e sétimo dias após o aparecimento da primeira flor foram $38^{\circ} \mathrm{C}$ e $29^{\circ} \mathrm{C}$, respectivamente, sob condições de baixa umidade relativa do ar.

Ao final do experimento, em 1995, um dos menores rendimentos médios foi observado no tratamento em que o guandu antecedeu o feijoeiro, diferindo significativamente daqueles observados nos tratamentos com as outras duas leguminosas, a mucuna preta e a crotalária juncea, porém não da aveia preta e do milho (tabela 19). Este resultado, além de ser contrário à expectativa inicial, foi discordante do relatado por Miyasaka et al. (1966d).

É que, conforme relatado anteriormente, houve um atraso nas datas de semeadura de todas as culturas incluídas nos esquemas de rotação, a cada ano, o que fez com que as culturas antecedentes ao feijoeiro fossem semeadas desde o final de março em 1993 até o final de abril em 1995, afetando mais o desenvolvimento de algumas espécies do que de outras.

Diante disso, o desenvolvimento das plantas de guandu foi muito mais prejudicado do que o das demais leguminosas, em função de sua maior sensibilidade às épocas de semeadura, com conseqüente baixa produção de fitomassa (tabela 4). Essa tendência foi amplamente discutida em literatura compilada por Amabile (1996) e também confirmada pelo próprio autor.

No Nordeste do Estado de São Paulo, mais precisamente nas regiões antigamente denominadas como alta e média Mojiana (de Pirassununga a Igarapava), inclui-se o município de Ribeirão Preto, local do presente estudo. Nessa regiâo a mucuna preta desenvolve-se vigorosamente no período de fevereiro-junho, sendo admitidas as semeaduras até o final de abril para a crotalária juncea e em fevereiro até no máximo no início de março para o guandu (Bulisani \& Roston, 1993). 
Em seus estudos sobre épocas de semeadura de adubos verdes nos cerrados do Brasil Central, em condições ambientais bem parecidas com as do presente estudo, Amabile (1996) observou pouca ou quase nenhuma variação no desenvolvimento das plantas de mucuna preta em relação às diferentes épocas de semeadura, as quais foram em novembro (início da estação chuvosa), no início de janeiro (meados da estação chuvosa e época de maior ocorrência de veranicos) e no início de março (final da estação chuvosa). A crotalária juncea apresentou um comportamento intermediário, enquanto que as reduções nas produções de fitomassa verde e seca foram muito mais acentuadas no guandu.

Em função das épocas de semeadura observadas nos quatro anos do presente estudo, as condições climáticas foram mais favoráveis ao desenvolvimento das plantas de mucuna preta, concordando com Amabile (1996) e Bulisani \& Roston (1993). Certamente, com a incorporação de sua fitomassa, imediatamente antes da semeadura do feijoeiro, obtiveram-se efetivos efeitos físicos no solo, em termos de melhoria de sua estrutura, devido a um aumento de sua porosidade em favor da permeabilidade. Isto se confirmou até mesmo nos maiores valores de infiltração básica obtidos neste tratamento (tabela 10). Como conseqüência direta destes efeitos, observou-se um aumento no rendimento do feijoeiro em sucessão, corroborando com diversos autores relacionados por Bulisani et al. (1992). Ainda, das três leguminosas em estudo, a mucuna preta é a espécie mais adaptada aos solos de textura argilosa e com fertilidade média a baixa.

Os menores valores observados no tratamento em que a aveia preta antecedeu a seqüência feijoeiro/milho (tabela 19) são discordantes do esperado e dos resultados relatados na literatura (Costa,1992; Derpsch, 1984; Derpsch \& Calegari, 1985 e Derpsch et al., 1985), possivelmente porque as condições ambientais no norte do Paraná fossem muito mais favoráveis ao desenvolvimento da aveia preta.

No presente trabalho, esta gramínea se desenvolveu em periodo considerado adequado porém, a sua fitomassa foi sempre menor do que aquela produzida tanto pela crotalária júncea quanto pela mucuna preta (tabela 4). Ainda, o seu cultivo repetido após a sucessão feijoeiro/milho pode ter acarretado problemas de disponibilidade de nutrientes, particularmente do nitrogênio, em função da relação $\mathrm{C} / \mathrm{N}$ de sua fitomassa 
ser muito superior à das leguminosas, conforme ressaltado por Derpsch \& Calegari (1992), nas culturas de soja e do feijoeiro.

Também para a cultura do milho, que foi irrigada, as temperaturas prevalecentes nesse mesmo periodo não pareceram ser muito adequadas, devido a esse atraso na época de semeadura. O híbrido C-701, utilizado neste trabalho, é recomendado para essa região norte e noroeste do Estado de São Paulo, porém para ele são admitidas semeaduras somente até 30 de março, para que não haja restrição ao desenvolvimento de suas plantas (Cargill, Sementes Híbridas, s/d). Inclusive, houve geada em 1994, inviabilizando a colheita de seus grãos o que contribuiu para a redução da sua fitomassa em relação aos demais anos (tabela 4 ).

Segundo Harris et al. (1966), a melhoria da estrutura de um solo pode ser obtida por meio da associação de gramíneas, com sistema radicular abundante e em constante renovação, com as leguminosas, que têm capacidade de fixação do nitrogênio atmosférico e de contribuição para a intensificação da atividade microbiológica do solo.

As diferenças observadas entre os valores de densidade do solo não foram significativas entre si, independente do tratamento e da profundidade (tabela 9) e nem sempre os menores resultados estiveram associados aos maiores rendimentos e viceversa, concordando com Bacchi (1976) e Voorhees et al. (1989). Em algumas situações a maior densidade do solo tanto superficial quanto no subsolo pode não ser prejudicial à produtividade das culturas, desde que as condições de umidade e de fertilidade deste solo sejam satisfatórias.

Nas leguminosas utilizadas como plantas de cobertura observa-se uma capacidade de extração de elementos menos solúveis e de mobilização de nutrientes nas camadas mais profundas do perfil do solo, em função, principalmente, do desenvolvimento quantitativo e em profundidade do seu sistema radicular (Inforzato, 1974 e Inforzato \& Tella, 1960). Franco \& Souto (1984) também enfatizaram esse aspecto, o que colaboraria para aumentar a eficiência de utilização dos adubos minerais, uma vez que alguns elementos como o potássio, o cálcio, o magnésio e o íon nitrato, que poderiam ser lixiviados, seria trazidos às camadas superficiais. Também, aqueles 
nutrientes de menor disponibilidade, como o fósforo e o molibdênio, poderiam ser "mineralizados", tornando-se mais disponiveis às culturas subseqüentes.

A inclusão de uma leguminosa em uma sequeencia de culturas pode representar ainda, a possibilidade de adição tanto do nitrogênio quanto de quantidade variável de fitomassa com uma menor relação $\mathrm{C} / \mathrm{N}$ em relação às gramíneas. Em consequência dessa relação $\mathrm{C} / \mathrm{N}$ mais estreita há maior rapidez na decomposição de seus resíduos, menor imobilização do nitrogênio e maior conservação da matéria orgânica do solo, conforme observado por Ambrosano (1995) e Heinrichs (1996).

Também, a utilização de espécies com elevada relação $\mathrm{C} / \mathrm{N}$ em sua fitomassa, como as gramíneas em geral, pode induzir uma deficiência inicial de nitrogênio no feijoeiro em sucessão, quando não adubado adequadamente com esse elemento, conforme observado por Miyasaka et al. (1966d).

Em estudos de dinâmica do ${ }^{15} \mathrm{~N}$ na cultura do milho, Ambrosano (1995) obteve uma menor mineralização do nitrogênio das leguminosas crotalária juncea e mucuna preta, em latossolo roxo, observando uma maior conservação do material orgânico tanto original quanto adicionado a esse solo. Ainda, cerca de $80 \%$ do nitrogênio adicionado pelas raízes dessas leguminosas permaneceram no solo e menos de $20 \%$ foram absorvidos pela cultura subseqüente, no caso o milho. Isso é indicativo de que as raizes, com maior relação $\mathrm{C} / \mathrm{N}$ do que a parte aérea, permanecem por mais tempo no solo.

Em relação ao estado nutricional das plantas de feijoeiro, verifica-se que, em média, apesar dos teores de fósforo no solo serem normais (tabelas 6,7 e 8), a adubação fosfatada utilizada no presente estudo não foi suficiente para suprir a necessidade das plantas dessa leguminosa. Isso se confirmou nas análises foliares nos anos de 1994 e 1995, em que apenas os teores de fósforo não eram adequados, sendo inclusive decrescentes a cada ano (tabela 11).

Entretanto, foram aplicados cerca de $56 \mathrm{~kg}$ de $\mathrm{P}_{2} \mathrm{O}_{5} / \mathrm{ha}$, que é uma quantidade até mesmo superior àquela recomendada por Ambrosano et al. (1996), tanto para o feijoeiro "das águas", quanto o "de inverno irrigado", tendo em vista produtividades esperadas de, respectivamente, 2,5 a 2,0 t/ha e 3,5 a 4,5 t/ha, em função do teor de fósforo determinado nas análises anuais de solo (tabelas 6,7 e 8 ). 
Mesmo naqueles tratamentos em que o feijoeiro foi antecedido por leguminosas, os teores foliares de fósforo foram inadequados. Apesar de haver comprovação científica sobre a capacidade das raízes de guandu para a exudação de ácidos orgânicos solubilizadores do fósforo imobilizado no solo (Ae et al., 1990; Otani \& Ae, 1997), o desenvolvimento das plantas, principalmente dessa leguminosa, foi prejudicado em função do atraso nas épocas de semeadura, já relatado anteriormente. Isso conseqüentemente reduziu a capacidade de aproveitamento do fósforo existente, porém não prontamente disponivel, conforme recentemente esclarecido por Otani \& Ae (1997). Amábile (1996) também relatou uma redução linear na concentração de fósforo nos tecidos do guandu quando a data de semeadura foi adiada de novembro para março.

Esse problema de deficiência nutricional também contribuiu para a redução dos valores de rendimento do feijoeiro porque o fósforo, apesar de ser o nutriente extraído em menor quantidade por essa leguminosa (Cobra Neto, 1967; Haag et al., 1967) é o mais limitante à sua produtividade (Oliveira et al., 1982).

É que o solo em questão, um latossolo roxo, apresenta elevados teores em argila, que variaram de $57,1 \%$ a $0-20 \mathrm{~cm}$ até $63,2 \%$ a $40-60 \mathrm{~cm}$ de profundidade (tabela 2), influenciando na menor quantidade de fósforo recuperado. Segundo Carvalho et al. (1995), apenas uma pequena parte dos sítios de absorção é ocupada pelos íons fosfatos e com elevada energia, em função da capacidade de reação do fósforo com óxidos de ferro e de alumínio, componentes predominantes da fração argila desse tipo de solo. Também, conforme Fageria \& Barbosa Filho (1985), do total do fertilizante aplicado há um aproveitamento de apenas 10 a $15 \%$ do fósforo pelas plantas de feijoeiro.

Ainda, apesar da acidez média a alta na camada arável, revelada nas análises de solo nos três anos (tabelas 6, 7 e 8), o desenvolvimento do feijoeiro não foi acentuadamente afetado, uma vez que, em média, os valores de rendimento, destacadamente naqueles tratamentos em que a mucuna preta e a crotalária juncea antecederam o feijoeiro, foram similares aos obtidos em experimentação com o feijoeiro irrigado (Carvalho et al., 1996; Magalhães \& Millar, 1978; Pires et al., 1991; Silveira et al., 1984) e, particularmente à média observada para o feijoeiro irrigado, no inverno, em Ribeirão Preto (Wutke, 1997) ${ }^{8}$. Devido à manutenção de teor normal de matéria orgânica 
ao longo dos anos no presente trabalho (tabelas 6,7 e 8), estabeleceu-se uma situação de maior tolerância a essa condição de acidez, concordando com Franco \& Souto (1984).

Os coeficientes de correlação simples entre rendimento em grãos e algumas características fisiológicas do feijoeiro, cultivar IAC-Carioca e alguns parâmetros do solo estão apresentados na tabela 20. Obteve-se correlação significativa do rendimento com o IAF em 1995; com a altura de plantas em 1994 e com o teor foliar de potássio em 1994, além de quantidade de matéria seca com o IAF em 1994 e 1995. Embora não tenha sido significativa, a correlação do rendimento com o teor foliar de potássio em 1995 apresentou um valor bem próximo do limite de significância, reforçando a tendência observada (tabela 20).

Estes resultados estão de acordo com as constatações obtidas tanto em feijoeiro (Miyasaka et al., 1966a; Stone et al., 1990) quanto em outras leguminosas como a soja (Nogueira, 1983; Pandey et al., 1984; Sivakumar \& Shaw, 1978); o caupi (Vigna unguiculata (L.) Walp. (Pandey et al., 1984; Turk \& Hall, 1980); o amendoim e o mungo (Pandey et al., 1984).

Os valores de correlação entre o rendimento e o sistema radicular do feijoeiro em 1994 e 1995 não foram significativos. Aproximaram-se bastante, porém, do limite de significância (tabela 20), sugerindo uma forte associação entre essas características e concordando com observações de Avilan-Rovira (1975), Osaki et al. (1997), Roder et al. (1989), Russell (1961) e Tanaka \& Fujita (1979).

De modo geral, os resultados obtidos no presente trabalho confirmaram a tendência de associação de muitas características fisiológicas da planta e relacionadas ao solo ao rendimento em grãos do feijoeiro, reforçando a validade dos dados obtidos. Estes, além de estarem de acordo com o nível de produtividade de $2.000 \mathrm{~kg} / \mathrm{ha}$, previsto para a safra de inverno", na mesma região em que foi desenvolvido o estudo, e estabelecido nas recomendações sobre zoneamento ecológico e épocas de semeadura para o feijoeiro no Estado de São Paulo (Pinzan et al., 1994), demonstram a viabilidade de utilização da adubação verde, particularmente da mucuna preta, no período não convencional de outono-inverno, anteriormente à seqüência feijoeiro/milho. 
Tabela 20: Coeficientes de correlação simples (r) entre características fisiológicas e agronômicas do feijoeiro, cultivar IAC-Carioca, em diferentes anos agrícolas.

\begin{tabular}{|c|c|c|c|}
\hline Correlação & 1993 & 1994 & 1995 \\
\hline Rendimento $x$ d. 0-20 & -.......- & ------ & $-0,258$ n.s. \\
\hline Rendimento $x \mathrm{~d} .20-40$ & - - - - & -..---.-- & $+0,182$ n.s. \\
\hline Rendimento $x$ VIB & ------- & -.-.--- & $+0,643$ n.s. \\
\hline Rendimento x CVS & ------- & $+0,619$ n.s. & $+0,682$ n.s. \\
\hline Rendimento $\times$ MS & ------- & $+0,593$ n.s. & $+0,706$ n.s. \\
\hline Rendimento $x$ LAF & -..--- & $+0,696$ n.s. & $+0,825^{*}$ \\
\hline Rendimento x Altura & $+0,591$ n.s. & $+0,904^{*}$ & $+0,105$ n.s. \\
\hline Rendimento x Raiz & $-0,263$ n.s. & $+0,765$ n.s. & $+0,742$ n.s. \\
\hline Rendimento $\times$ Estande & $-0,467$ n.s. & $+0,068$ n.s. & $+0,357$ n.s. \\
\hline Rendimento $\times \mathrm{N}$ folha & --.-n-- & $+0,381$ n.s. & $-0,159$ n.s. \\
\hline Rendimento $\times$ P folha & -n-n-n-- & $+0,307$ n.s. & $+0,383$ n.s. \\
\hline Rendimento $\times \mathrm{K}$ folha & ------- & $+0,819^{*}$ & $+0,737$ n.s. \\
\hline Rendimento x Ca folha & 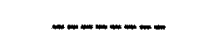 & $+0,412$ n.s. & $-0,228$ n.s. \\
\hline Rendimento x Mg folha & ------ & $+0,509$ n.s. & $-0,241$ n.s. \\
\hline Rendimento $\mathrm{x} S$ folha & -...-...- & $+0,012$ n.s. & $+0,618$ n.s. \\
\hline Raiz x d.0-20 & ------ & ------- & $+0,221$ n.s. \\
\hline Raiz x d.20-40 & ---.--- & --------- & $-0,122$ n.s. \\
\hline Raiz x VIB & ------- & --.---.- & $+0,673$ n.s. \\
\hline Raiz $\times$ CVS & 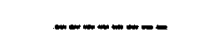 & $+0,528$ n.s. & $+0,739$ n.s. \\
\hline Raiz x MS & -...-- & $+0,895^{*}$ & $+0,791$ n.s. \\
\hline Raiz x IAF & -.m-n-m- & $+0,859^{*}$ & $+0,738$ n.s. \\
\hline Raiz x Altura & $-0,565$ n.s. & $+0,612$ n.s. & $-0,200$ n.s. \\
\hline Raiz $\times$ Estande & -.-.-..-- & $-0,197$ n.s. & $+0,702$ n.s. \\
\hline Raiz $\times$ N folha & -------- & $+0,072$ n.s. & $+0,052$ n.s. \\
\hline Raiz x P folha & -.....-- & $+0,466$ n.s. & $+0,660$ n.s. \\
\hline Raiz $\times K$ folha & -------- & $+0,565$ n.s. & $+0,850^{*}$ \\
\hline Raiz x Ca folha & -.--n- & $+0,145$ n.s. & $+0,315$ n.s. \\
\hline Raiz $\times$ Mg folha & --.-.--- & $+0,002$ n.s. & $+0,104$ n.s. \\
\hline Raiz x S folha & - & $+0,545$ n.s. & $+0,171$ n.s. \\
\hline VIB $x$ d.0-20 & -. & ----n-n-- & $+0,311$ n.s. \\
\hline VIB $x$ d. $20-40$ & ------- & --..-..--- & - 0,372 n.s. \\
\hline MS x Altura & ------- & $+0,291$ n.s. & $+0,242$ n.s. \\
\hline CVS x Altura & -------- & $+0,444$ n.s. & $-0,552$ n.s. \\
\hline CVS x MS & -----n- & $+0,535$ n.s. & $+0,467$ n.s. \\
\hline CVS $\times$ IAF & -...-...- & $+0,726$ n.s. & $+0,398$ n.s. \\
\hline MS $\times$ IAF & ------- & $+0,880^{*}$ & $+0,922 *$ \\
\hline IAF x Altura & -..-n- & $+0,523$ n.s. & $+0,461$ n.s. \\
\hline
\end{tabular}

Para 1993: $r>0,878$ significativo a $5 \%(*)$ e $r>0,959$ significativo a $1 \%\left({ }^{* *}\right)$.

Para 1994 e $1995: r>0,812$ significativo a $5 \%\left({ }^{*}\right)$ e $r>0,917$ significativo a $1 \%(* *)$

*d. $0-20$ e d. $20-40=$ densidade do solo a $0-20 \mathrm{~cm}$ e a $20-40 \mathrm{~cm}$ de profundidade, respectivamente; VIB = valor de infiltração básica; $\mathrm{CVS}$ = cobertura vegetal do solo; $\mathrm{MS}$ = quatidade de matéria seca; $\mathrm{IAF}=$ indice de área foliar. 


\section{CONSIDERAÇÕES FINAIS}

O cultivo do feijoeiro irrigado no Estado de São Paulo tem apresentado um crescimento acentuado nos últimos anos às custas porém, de algum desequilibrio ambiental, com conseqüentes prejuizos à sua produção e produtividade. Essa constatação evidenciou a necessidade de reavaliação das práticas agrícolas adotadas para a produção do feijoeiro e do estabelecimento de estratégias racionais de manejo, particularmente nas regiões Norte e Nordeste deste Estado, pioneiras na utilização de irrigação por pivô central.

Nessa situação, a rotação de culturas pode influenciar positivamente a produtividade dessa leguminosa, considerando-se, conjuntamente, a inclusão de culturas de interesse econômico aos produtores e a preservação, manutenção, restauração e melhoria dos recursos naturais.

A avaliação de diversas características da planta e também do solo pode ser um procedimento de muita valia na definição de melhores sequêencias de culturas, em função ainda das condições ambientais que prevalecem em uma determinada situação agrícola. Assim é que, no presente trabalho, apenas a incorporação de resíduos vegetais imediatamente antes da semeadura do feijoeiro não impediu a diminuição do nível de fertilidade na camada arável durante os anos, não sendo possível prescindir da adubação química. Entretanto, a manutenção de teores considerados normais de fósforo, potássio, cálcio, magnésio e, particularmente da matéria orgânica na profundidade de $0-20 \mathrm{~cm}$, mesmo diante de condições ambientais nem sempre as mais adequadas, foi favorável à obtenção de rendimentos em grãos.

Considerando-se o atraso anual nas semeaduras das culturas envolvidas, contrariamente ao estabelecido no início da experimentação, tais rendimentos foram até 
muito satisfatórios. Por outro lado, a rotação de culturas permitiu o aumento do $\mathrm{pH}$ e do indice de saturação por bases e a diminuição dos teores de $\mathrm{H}+\mathrm{Al}$ em profundidade, o que se refletiu, de certa maneira, no desenvolvimento radicular ainda observado nas camadas mais profundas do solo. A distribuição das raizes no perfil do solo também foi igualmente afetada pelas rotações, uma vez que a maior resistência à penetração das raizes passou a ser detectada em maiores profundidades, definindo uma profundidade efetiva de 35 a $40 \mathrm{~cm}$, nessa situação.

Como efeito prático das rotações estudadas ao longo dos anos, houve uma tendência para a associação de valores maiores de infiltração básica, de teores foliares de potássio, de cobertura vegetal do solo, de quantidade de matéria seca produzida, de IAF e do comprimento total de raizes, ao rendimento em grãos do feijoeiro irrigado. Assim, a utilização desses parâmetros é viável, em termos de fornecer as informações necessárias a uma tomada de decisões.

A conjugação desses fatores às condições climáticas reinantes favoreceu diferentemente o rendimento do feijoeiro nos diversos anos e tratamentos. Considerandose a média dos quatro anos de experimentação e as alterações não previstas a princípio, principalmente em relação às datas de semeadura, o desenvolvimento de algumas espécies foi menos prejudicado do que o de outras, possibilitando identificar as melhores seqüências de culturas para o feijoeiro nessa situação agricola específica.

Assim é que, como efeito das próprias rotações, em relação ao pousio, destacou-se o cultivo da mucuna preta, que não diferiu significativamente apenas dos tratamentos com a crotalária júncea e com o milho, cultivados no período não convencional de outono-inverno, após a seqüência feijoeiro irrigado/milho de ciclo precoce. Com isso, viabilizou-se a utilização de três culturas no mesmo ano agricola, com garantia de aumentos no rendimento do feijoeiro em relação ao pousio. 


\section{CONCLUSÕES}

De acordo com os resultados obtidos nas condições do presente estudo pode-se concluir que:

- A inclusão da mucuna preta no periodo não convencional de cultivo no outono-inverno, na seqüência feijoeiro irrigado/milho de ciclo precoce, contribui para o aumento no rendimento do feijoeiro, em relação ao pousio;

- A avaliação do comprimento do sistema radicular é um indicador eficaz dos efeitos da rotação de culturas no desenvolvimento do feijoeiro irrigado;

- A inclusão da mucuna preta e da crotalária juncea, no período não convencional de cultivo no outono-inverno tem efeitos favoráveis para a subseqüente cultura do feijoeiro, relativamente aos teores foliares de potássio; à cobertura vegetal do solo e ao índice de área foliar (IAF). A velocidade de infiltração básica do solo (VIB) também é favorecida;

- A rotação de culturas do feijoeiro irrigado com milho e adubos verdes favorece a redução da resistência do solo à penetração; garante a manutenção do teor normal de matéria orgânica do solo e possibilita a redução da acidez e o aumento do índice de saturação por bases (V\%) em profundidade. 


\section{REFERÊNCIAS BIBLIOGRÁFICAS}

ABAWI, G. S.; PASTOR-CORRALES, M. A. Root rots of beans in Latin America and Africa: Diagnosis, research methodologies, and management strategies. Cali: CIAT, 1990. 114 p.

ABBOUD, A.C.S.; DUQUE, F.F. Efeito de materiais orgânicos e vermiculita sobre a sequência milho-feijão. Pesquisa Agropecuária Brasileira, v.21, n.3, p.227-236, 1986.

ABELES, F.B; GAHAGAN, H.E. Abscision; the role of ethylene, ethylene analogues, carbon dioxide and oxygen. Plant Physiology, v.43, p. 1255-1258, 1968.

Ae, N.; ARIHARA, J; OKADA, K.; YOSHIHARA, T; JOHANSEN, C. Phosphorus uptake by pigeon pea and its role in cropping systems of the Indian subcontinent. Science, v. 288 , p. $477-480,1990$.

ALMEIDA, F. S. A alelopatia e as plantas. Londrina: IAPAR, 1988. 60 p. (IAPAR, Circular, 53).

ALMEIDA, L.D'A.de; MIYASAKA, S.; IGUE, T.; ORTOLANI, A.A.; ALOISI SOBRINHO, J.; SORDI, G. de; ALVES, S. Efeitos na produção do feijão da "seca" da irrigação, da adubação mineral e da incorporação ao solo da massa vegetal semidecomposta de Crotalaria juncea L. Bragantia, v. 30, p. 289-304, 1971.

ALMEIDA, L.D'A. de; MIYASAKA, S; BULISANI, E.A.; LAUN, C.R.P.; CRUZ, L.S.P.; VEIGA, A.A. Efeitos da época de incorporação ao solo, de restos vegetais de soja comum (Glycine max Merrill), sobre a produção do feijoeiro. Bragantia, v.31, tomo único, p. 17-40, 1972. 
ALMEIDA, L.D'A.de; BULISANI, E.A.; MIYASAKA, S.; SORDI, G. de; ALOISI SOBRINHO, J.; ALVES, S. Efeito da incorporação de massa vegetal, de adubação e do espaçamento na produção do feijoeiro. Bragantia, v.34, tomo único, p. XLII XIVII, 1975. (Nota, 10)

ALVES, M. C. Sistemas de rotação de culturas com plantio direto em latossolo roxo: feitos nas propriedades físicas e químicas. Piracicaba, 1992. 173 p. Tese (Doutorado) Escola Superior de Agricultura "Luiz de Queiroz", Universidade de São Paulo.

ALVIM, R.; ALVIM, P.de T. Efeito da densidade de plantio no aproveitamento da energia luminosa pelo milho (Zea mays) e pelo feijão (Phaseolus vulgaris), em culturas exclusivas e consorciadas. Turrialba, v.19, p.389-93, 1969.

AMABILE, R. F. Comportamento de adubos verdes em épocas de semeadura nos cerrados do Brasil Central. Piracicaba, 1996. 123 p. Dissertação (M.S.) - Escola Superior de Agricultura "Luiz de Queiroz", Universidade de São Paulo.

AMBROSANO, E. J. Dinâmica do nitrogênio dos adubos verdes, crotalária juncea (Crotalaria juncea) e mucuna-preta (Mucuna aterrima), em dois solos cultivados com milho. Piracicaba, 1995. 83 p. Tese (Doutorado) - Escola Superior de Agricultura "Luiz de Queiroz", Universidade de São Paulo.

AMBROSANO, E.J.; WUTKE, E.B.; BULISANI, E.A.; CANTARELLA, H. Feijão. In: RAIJ, B. van; CANTARELLA, H; QUAGGIO, J.A.; FURLANI, A.M.C. (Eds.). Recomendações de adubação e calagem para o Estado de São Paulo. $2^{a}$ ed. Campinas: Instituto Agronômico \& Fundação IAC, 1996. p.194-195. (Boletim Técnico, 100)

ARF, O.; SILVA, L.S. da; BUZETTI, S.; ALVES, M.C.; SÁ, M.E. de; RODRIGUES, R.A.F.; HERNANDEZ, F.B.T. Efeito da rotação de culturas, adubação verde e nitrogenada sobre o rendimento do feijão (Phaseolus vulgaris L.). In: REUNIÃO NACIONAL DE PESQUISA DE FEIJÃO, 5., 1996, Goiânia. Anais. Goiânia: EMBRAPA-CNPAF- APA, 1996. v.1. p:435-437 (EMBRAPA-CNPAF Documentos, 69). 
ARNAUD-SANTANA, E.; PENA-MATOS, E.;COYNE, D.P.; VIDAVER, A.K. Longevity of Xanthomonas campestris pv. phaseoli in naturally infested dry bean (Phaseolus vulgaris) debris. Plant Disease, v.75, p. 952-953,1991.

ARRUDA, F.B. Determinação da cobertura do solo durante o ciclo das culturas. Revista Brasileira de Ciência do Solo, v. 8, p.145-150, 1984.

ARRUDA, F.B. Uso da água na produção agrícola. In: Simpósio sobre o manejo de água na agricultura, Campinas, 1987. Anais. Campinas, Fundação Cargill, 1987, p. 177-199.

ARRUDA, F.B. Avaliação do desempenho das culturas. In: CURSO PRÁTICO INTERNACIONAL DE AGROMETEOROLOGIA, 3., Campinas, 1989. Apostila. Campinas: Instituto Agronômico, 1989. 14 p.

ARRUDA, F. B.; FUJIWARA, M.; CALHEIROS, R.; PIRES, R.C. de M.; SAKAI, E. A agricultura irrigada ante a administração dos recursos hídricos do Estado de São Paulo. Laranja, v.15, n.2, p.343-364, 1994.

ARZENO, J. L. Avaliação fisica de diferentes manejos de solo em um latossolo roxo distrófico. Piracicaba, 1990. 259 p. Dissertação (M.S.) - Escola Superior de Agricultura "Luiz de Queiroz", Universidade de São Paulo.

ASLANDER, A.; ARMOLIK, N. Influencia que ejercen los materiales organicos sobre la fijación del potasio em el suelo. Separata de Transactions of the Royal Institute of Technology, v. 236. p.1-2, 1965 .

AVILAN-ROVIRA, L. A. A. Estudo do sistema radicular do feijoeiro (Phaseolus vulgaris L.) var. Carioca. Piracicaba, 1975. 86 p. Tese (Doutorado) - Escola Superior de Agricultura "Luiz de Queiroz", Universidade de São Paulo. 
BACCHI, O. O. S. Efeitos da compactação sobre o sistema solo-planta em cultura de cana-de-açúcar. Piracicaba, 1976. 67 p. Dissertação (M.S.) - Escola Superior de Agricultura "Luiz de Queiroz", Universidade de São Paulo.

BALIGAR, V.C.; NASH, V.E.; HARE, M.L.; PRICE Jr., J.A. Soybean root anatomy as influenced by soil bulk density. Agronomy Journal, v. 67, p. 842-844, 1975.

BARBER, S.A.; MACKAY, A.D.; KUCHENBUCH, R.O; BARRACLOUGH, P.B. Effects of soil temperature and water on maize root growth. Plant Soil, v. 111, p.267269,1988 .

BASCUR, G.; OLIVA, M.A.; LAING, D. Termometria infrarroja en selection de genotipos de frijol (Phaseolus vulgaris L. ) resistentes a la sequia. II. Crecimiento y productividad. Turrialba, v.35, n.1, p.49-53, 1985.

BATAGLIA, O.C.; FURLANI, A.M.C.; TEIXEIRA, J.P.F.; FURLANI, P.R.; GALLO, J.R. Métodos de análise química de plantas. Campinas: Instituto Agronômico, 1983. 48 p. (Boletim Técnico, 78).

BENTON-JONES JR., J.; WOLF, B.; MILLS, H.A. Plant analysis hand book. Athens: Micro-macro Publ., Inc. 1991. 213 p.

BERGAMASCHI, H.; CUNHA, G.R.da; BERLATO, M.A.; BRUNINI, O; VIEIRA, H.J. Parâmetros aerodinâmicos de uma cultura de Phaseolus vulgaris L. In: CONGRESSO BRASILEIRO DE AGROMETEOROLOGIA, 4., Belém, 1977. Resumos. Belém: Sociedade Brasileira de Agrometeorologia, 1977. p. 376-377.

BERNARDO, S.; GALVÃO, J.D.; GUERINI, H.; CARVALHO, J.B. Efeito de níveis de água no solo sobre a produção do feijoeiro. Seiva, v. 30, n. 71, p. 7-13, 1970. 
BIDDULPH, O.; CORY, R.; BIDDULPH, S. Translocation of calcium in the bean plant. Plant Physiology, v. 34, p. 512-519, 1959.

BIDDULPH, O.; NAKAYAMA, F.S.; CORY, R. Transpiration stream ascension of calcium. Plant Physiology, v.36, p. 429-436, 1961.

BLACK, C. A. Relaciones suelo-planta. Buenos Aires, Hemisferio Sur, 1975. 444 p.

BOWER, $H$. Intake rate: cylinder infiltrometer. In: KLUTE, A., ed. Methods of soil analysis. Part 1 - Physical and mineralogical methods. American Society of Agronomy, Inc. and Soil Science Society of America, Inc., Madison, 1986. 1188 p.

BÖHM, W. Methods of studying root systems. Berlim: Springer-Verlag. 1979. 189 p.

BÖHM, W.; MADUAKOR, H.; TAYLOR, H. M. Comparison of five methods for characterizing soybean rooting density and development. Agronomy Journal, v.69, p.415-419, 1977.

BRAGA, N. R.; BULISANI, E. A. Feijão-Guandu (Cajanus cajan (L.) Millsp.). In: PEDRO JÚNIOR, M. P.; BULISANI, E.A.; POMMER, C. V.; PASSOS, F. A.; GODOY, I. J. de; ARANHA, C., ed. Instruções Agrícolas para o Estado de São Paulo. $4^{\text {a }}$ ed. rev. atual. Campinas, 1987. p.97. (Boletim Técnico, 200).

BRANDES, D. Análise de crescimento do feijoeiro (Phaseolus vulgaris L.). Efeito da densidade e da época de plantio. Viçosa, 1971. 109 p. Dissertação (M.S.) Universidade Federal de Viçosa.

BRANDES, D.; MAESTRI, M. VIEIRA, C.; GOMES, F.R. Efeitos da população de plantas e da época de plantio no crescimento do feijoeiro (Phaseolus vulgaris L.). II. Análise de crescimento. Experientiae, v. 15, n.1, p.23-30, 1973. 
BROUGHAM, R.W. Interception of light by foliage of pure and mixed stands of pasture plants. Australian Journal Agricultural Reasearch, v. 9, p.39-52, 1958.

BROWN, D. A.; SCOTT, H. don. Dependence of crop growth and yield on root development and activity. In: BARBER, S.A. \& BOULDIN, D.R., ed. Roots, nutrient and water influx, and plant growth. Madison, Soil Science Society of America, 1984. cap. 6, p.: 101-36.

BRUULSEMA, T. W.; CHRISTIE, B. R. Nitrogen contribution to succeeding corn from alfafa and red clover. Agronomy Journal, v. 79, n. 1, p. 96-100, 1987.

BULISANI, E.A. Crescimento e absorção de nutrientes em cinco cultivares de feijoeiro (Phaseolus vulgaris L.). Piracicaba, 1994. 150 p. Tese (Doutorado) - Escola Superior de Agricultura "Luiz de Queiroz", Universidade de São Paulo.

BULISANI, E. A.; ALMEIDA, L. D. A. de. Feijão (Phaseolus vulgaris L.). In: PEDRO JÚNIOR, M. P.; BULISANI, E.A.; POMMER, C. V.; PASSOS, F. A.; GODOY, I. J. de; ARANHA, C., ed. Instruções Agrícolas para o Estado de São Paulo. $4^{\mathrm{a}}$ ed. rev. atual. Campinas, 1987. p.91-2. (Boletim Técnico, 200).

BULISANI, E.A.; BRAGA, N.R. Mucuna-preta (Stizolobium aterrimum Piper \& Tracy). In: PEDRO JÚNIOR, M. P.; BULISANI, E.A.; POMMER, C. V.; PASSOS, F. A.; GODOY, I. J. de; ARANHA, C., ed. Instruções Agrícolas para o Estado de São Paulo $4^{\text {a }}$ ed. rev. atual. Campinas, 1987. p. 154. (Boletim Técnico, 200).

BULISANI, E.A.; ROSTON, A.J. Leguminosas: adubação verde e rotação de culturas. In: WUTKE, E.B.; BULISANI, E.A.; MASCARENHAS, H.A.A. (Coord.). Curso sobre adubação verde no Instituto Agronômico, 1., Campinas, Instituto Agronômico, 1993. p.:13-16 (Documentos IAC, 35). 
BULISANI, E.A.; ALMEIDA, L.D.A. de; ROSTON, A.J. A cultura do feijoeiro no Estado de São Paulo. In: BULISANI, E.A. (Coord.).Feijão: fatores de produção e qualidade. Campinas, Fundação Cargill,1987. p.29-88.

BULISANI, E. A.; COSTA, M. B. B. da; MIYASAKA, S. Adubação verde em São Paulo. In: COSTA, M. B. B.da (Coord.). Adubação verde no sul do Brasil. Rio de Janeiro: AS-PTA, 1992. p. 59-81.

BULISANI, E. A.; MIYASAKA, S.; ALMEIDA, L. D.A. de; SCARANARI, H. J; PINTO, H. S. Estudos ecológicos com o feijoeiro (Phaseolus vulgaris L.).I- Efeito da incorporação de massa vegetal ao solo e do sombreamento parcial. Bragantia, v. 31, tomo único, p. 83-95, 1972.

CAIXETA, T. J. Irrigação do feijoeiro. Informe Agropecuário, v.4, n.46, p.36-40,1978.

CAIXETA, T. J.; PURCINO, J. R. C.; SILVA, L. Irrigação de algumas culturas. Informe Agropecuário, v.9, n. 100, p.65-76, 1983.

CALEGARI, A. Adubação verde no Paraná. In: COSTA, M.B.B. da. (Coord.). Adubação verde no Sul do Brasil. Rio de Janeiro: AS-PTA, 1992 . p.83-119.

CAMARGO, O.A.de Compactação do solo e desenvolvimento de plantas. Campinas, Fundação Cargill, 1983. 44 p.

CAMARGO, T.; HERMANN, J. Contribuição para o estudo da dubação verde das terras roxas cansadas. São Paulo, Diretoria de Publicidade Agrícola da Secretaria da Agricultura, Indústria e Comércio do Estado de São Paulo. 1928,

CAMARGO, O. A. de; MONIZ, A. C.; JORGE, J. A.; VALADARES, J. M. A. da S. Métodos de análise química, mineralógica e física de solos do Instituto Agronômico de Campinas. Campinas: Instituto Agronômico, 1986. 94 p. (Boletim técnico, 106) 
CANTARELLA, H.; ANDRADE, J. C. O sistema internacional de unidades e a ciência do solo. Boletim Informativo da Sociedade Brasileira de Ciência do Solo, v. 17, n.3, p. 91-102, 1992.

CARNEIRO, R. G.; CARNEIRO, R. M. D. E. Seleção preliminar de plantas para rotação de culturas em áreas infestadas por Meloidogyne incognita nos anos de 1979 e 1980. Sociedade Brasileira de Nematologia, v. 6, p.141-148, 1982.

CARGILL Sementes Hibridas. 91 p. 1996.

CAROLUS, R.L. Effect od certain ions used singly and in combination on the growth and potassium, calcium and magnesium absorption of the bean plant. Plant Physiology, v.13, p. 349-369, 1938.

CARVALHO, A.M.de; FAGERIA, N.K.; OLIVEIRA, I.P. de; KINJO, T. Resposta do feijoeiro à aplicação de fósforo em solos dos cerrados. Revista Brasileira de Ciência do Solo, v. 19, n. 1, p. 61-67, 1995.

CARVALHO, M.A.C de.; ARF, O.; SÁ, M.E. de. Efeito de espaçamentos entre linhas e datas de semeadura no desenvolvimento de cultivares de feijoeiro (Phaseolus vulgaris L.) no período de inverno. In: REUNIÃO NACIONAL DE PESQUISA DE FEIJÃO, 5., 1996, Goiânia. Anais. Goiânia: EMBRAPA-CNPAF-APA, 1966. v.1. p.447-449 (Embrapa-CNPAF. Documentos, 69).

CASTRO, F. S. Conservación de suelos. Barcelona, Salvat, 1956. 298 p.

CASTRO, O. M. de. Sistemas de preparo do solo e rotação de culturas para milho e soja: relatório técnico anual. Campinas: Instituto Agronômico, 1991. n.p. (Mimeografado) 
CASTRO, O. M. de. Comportamento físico e químico de um latossolo roxo em função do seu preparo na cultura do milho (Zea mays L.). Piracicaba, 1995. 174 p. Tese (Doutorado) - Escola Superior de Agricultura "Luiz de Queiroz", Universidade de São Paulo.

CASTRO, O.M. de; De MARIA, I.C. Plantio Direto e Manejo do Solo. In: WUTKE, E.B.; BULISANI, E.A.; MASCARENHAS, H.A.A., coord. Curso sobre Adubação Verde no Instituto Agronômico,1.,Campinas,1993.p.87-107.(Documentos IAC,35)

CASTRO, O. M. de; LOMBARDI NETO, F.; QUAGGIO, J. A.; DE MARIA, I. C.; VIEIRA, S.R.; DECHEN, S. C. F. Perdas por erosão de nutrientes vegetais na sucessão soja/trigo em diferentes sistemas de manejo. Revista Brasileira de Ciência do Solo, v. 10, p. 293-297, 1986.

CASTRO, O.M. de; VIEIRA, S.R.; DE MARIA, I.C. Sistemas de preparo do solo e disponibilidade de água. In: VIEGAS, G.P., ed. Simpósio sobre o manejo de água na agricultura, Campinas: Fundação Cargill, 1987a. p. 27-51.

CASTRO, O. M. de; CAMARGO, O. A. de; VIEIRA, S. R.; DECHEN, S. C. F.; CANTARELlA, $H$. Caracterização química e física de dois latossolos em plantio direto e convencional. Campinas, Instituto Agronômico, 1987b. 23 p. (Boletim científico, 11).

CENTURION, J.F.; DEMATTÊ, J.L.I.; FERNANDES, F.M. Efeitos de sistemas de preparo nas propriedades químicas de um solo sob cerrado cultivado com soja. Revista Brasileira de Ciência do Solo, v.9, p. 267-270, 1985.

CHAGAS, J.M. Plantio. In: ZIMMERMANN, M.J. de O.; ROCHA, M.; YAMADA, T. (Ed.). A cultura do feijoeiro: fatores que afetam a produtividade. Piracicaba: Associação Brasileira para a Pesquisa da Potassa e do Fosfato,1988. p.303-313. 
CHAGAS, J.M.; ARAÚJO, G.A.de A.; OLIVEIRA, F. Efeito da rotação de culturas em áreas irrigáveis sobre a produção de feijão no inverno em Leopoldina. In: REUNIÃO NACIONAL DE PESQUISA DE FEIJÃO, 4., Londrina, 1993. Reunião Nacional de Pesquisa de Feijão, 4., Londrina, 1993. Resumos. Londrina: IAPAR, 1993. p.58.

CIAT. Sistemas de producción de frijol. Cali, Colômbia, 1975, 64 p.

CINTRA, F.L.D.; MIELNICZUCK, J. Potencial de algumas espécies vegetais para a recuperação de solos com propriedades fisicas degradadas. Revista Brasileira de Ciência do Solo, v.7, p.197-201, 1983.

COBRA NETO, A. Absorção e deficiência dos macronutrientes pelo feijoeiro (Phaseolus vulgaris L.; var. Roxinho). Piracicaba, 1967. 69 p. Tese (Doutorado) - Escola Superior de Agricultura "Luiz de Queiroz", Universidade de São Paulo.

COBRA NETO, A.; ACCORSI, W. R.; MALAVOLTA, E. Estudos sobre a nutrição mineral do feijoeiro (Phaseolus vulgaris L., var. Roxinho). Anais da Escola Superior de Agricultura "Luiz de Queiroz", v. 28, p.257-274, 1971.

COLMENARES, J. M. ; BLASCO, M. Effects of different salts added to soil on bean (Phaseolus vulgaris L.) production. Turrialba, v. 24, n.31, p.38-46, 1974.

COMUNICAÇÃO DA PESQUISA AGROPECUÁRIA. Lançamentos de 1988: Feijão IAC-Carioca-SH. Comunicação da Pesquisa Agropecuária, v.6, n.2, p.2, 1988.

COSTA, M. B. B. Adubação orgânica; nova síntese e novo caminho para a gricultura. São Paulo, ICONE, 1985. 104 p.

COSTA, J.G.C. da; KOHASHI-SHIBATA, J.; COLIN, S.M. Plasticidade no feijoeiro comum. Pesquisa Agropecuária Brasileira, v.18, n.2, p.159-167, 1983. 
COYNE, D. P. Correlation of yield components in beans. Annual Report of the Bean Improvement Cooperative, v.12, p.13-15,1969.

DAKER, A. A água na agricultura: irrigação e drenagem. $6^{a}$ ed. Rio de Janeiro, Freitas Bastos, 1984, v.3, $543 \mathrm{p}$.

DALLA-ROSA, A. Práticas mecânicas e culturais na recuperação de características físicas de solos degradados pelo cultivo-solo Santo Ângelo (Latossolo Roxo distrófico). Porto Alegre, 1981. 136 p. Dissertação (M.S.) - Faculdade de Agronomia, Universidade Federal do Rio Grande do Sul.

DAVIS, J.F. The effects of some environmental factors on the set pods and yield of white cowpea beans. Journal of Agricultural Research, v. 70, p. 237-49, 1945.

DAVIS, J.H.C.; EVANS, A.M. Selection indices using plant type characteristics in navy beans (Phaseolus vulgaris L.). Journal of Agricultural Research, v.89, p. 341-348, 1977.

DE MARIA, I.C. Razão de perdas de solo para alguns sistemas de manejo da cultura de milho. Piracicaba, 1995. 93 p. Tese (Doutorado) - Escola Superior de Agricultura "Luiz de Queiroz", Universidade de São Paulo.

DE MARIA, I. C.; CASTRO, O. M. de. Fósforo, potássio e matéria orgânica em um latossolo roxo, sob sistemas de manejo com milho e soja. Revista Brasileira de Ciência do Solo, v. 17, p. 471-477, 1993.

DECHEN, S. C. F; LOMBARDI NETO, F.; CASTRO, O. M. de. Gramíneas e leguminosas e seus restos culturais no controle da erosão em latossolo roxo. Revista Brasileira de Ciência do Solo, v. 5, n. 2, p. 133-137, 1981. 
DEMATTÊ, J. B.I.; DEMATTÊ, J.D.I.; MIYASAKA, S.; ALMEIDA, L. D'A.de; BULISANI, E.A.; IGUE, T.; ALVES, S. Irrigação, adubação mineral e matéria orgânica em cultura de feijão. Campinas: Instituto Agronômico, 1974. 27 p. (Boletim técnico, 15).

DERPSCH, R. Alguns resultados sobre adubação verde no Paraná. In: Adubação verde no Brasil. Campinas: Fundação Cargill, 1984. p. 268-279.

DERPSCH, R.; CALEGARI, A. Guia de plantas para adubação verde de inverno. Londrina: IAPAR, 1985. 96 p. (Documentos IAPAR, 9).

DERPSCH, R.; CALEGARI, A. Plantas para adubação verde de inverno. Londrina, IAPAR, 1992. 80 p. (IAPAR, Circular, 73).

DERPSCH, R.; SIDIRAS, N.; HEINZMANN, F. X. Manejo do solo com coberturas verdes de inverno. Pesquisa Agropecuária Brasileira, v.20, n. 7, p. 761-773, 1985.

DICKSON, M.K.; BOETTGER, M.A. Effect of high and low temperatures on pollen germination and seed set in snaps beans. Journal of American Society of Horticultural Science, v. 109, n. 3, p. 372-374, 1984.

DOORENBOS, J.; KASSAM, A. H. Feijão. In: GHEYI, H. R.; SOUSA, A. A. de; DAMASCENO, F. A. V.; MEDEIROS, J. F. de., trad. Efeito da água no rendimento das culturas. Campina Grande, UFPB. p.117-121, 1994 (Estudos FAO: Irrigação e Drenagem, 33).

DOURADO-NETO, D.; van LIER, Q. de J. Programa para elaboração do balanço hídrico para culturas anuais e perenes. Piracicaba, ESALQ/Departamento de Agricultura, 1991. 58 p. (Manual do usuário) 
DOURADO-NETO, D.; SAAD, A. M.; van LIER, Q. de J. Controle de irrigação: método conjugado. In: FANCELLI, A.L.; DOURADO-NETO, D. (ed.). Feijão Irrigado. $3^{\text {a }}$ ed. Piracicaba; Departamento de Agricultura, ESALQ-USP, 1992. p.:

DRIESSEN, P. M. A first introduction to quantified land evaluation procedures. Wageningen, Centre for World Food Studies, 1986. $116 \mathrm{p}$.

DUARTE, R. A.; ADAMS, M. W. A path coefficient analysis of some yield component interrelations in field beans (Phaseolus vulgaris L.). Crop Science, v. 12, p. 579-582, 1972.

EHLERS, W. Observation on earthworm channels and infiltration on tilled and untilled loess soil. Soil Science, v. 11, p. 242-249, 1975.

ELTZ , F. L. F.; PEIXOTO, R. T. G.; JASTER, F. Efeitos de sistemas de preparo do solo nas propriedades fisicas e químicas de um latossolo bruno álico. Revista Brasileira de Ciência do Solo, v. 13, p. 259-267, 1989.

EMERSON, R. A. A genetic study of plant height in Phaseolus vulgaris. Nebraska Agricultural Experimental Station Research Bulletin, $\mathrm{n}^{\circ}$ 7, 1916.

FAGERIA, N.K.; BARBOSA FILHO, M.P. Phosphorus fixation in oxisol of Central Brazil. Fertilizers and Agriculture, v. 49, p. 33-37, 1987.

FAGERIA, N.K.; SOUZA, N.P de. Resposta das culturas de arroz e feijão em sucessão à adubação em solo de cerrado. Pesquisa Agropecuária Brasileira, v.30, p. 359-368 1995. 
FAGERIA, N. K.; BALIGAR, V. C.; JONES, C. A. Common bean and cowpeas. In: MARCEL DEKKER (Inc.). Growth and mineral nutrition of field crops. Nova Iorque, Basileia, Hong Kong. 476 p. 1981.

FANCELLI, A.L. Fenologia e exigências climáticas do feijoeiro. In: FANCELLI, A. L.; coord. Feijão irrigado. Piracicaba. FEALQ; ESALQ/USP, Departamento de Agricultura. 1990. p.7-24.

FANCELLI, A.L.; DOURADO-NETO, D. Ecofisiologia e Fenologia do Feijoeiro. In: FANCELLI, A.L. \& DOURADO-NETO, D.,coord. Tecnologia da produção do feijão irrigado. Piracicaba: ESALQ/USP, Departamento de Agricultura,1997.p. 100-120.

FARIA, R.T.de; FOLEGATTI, M.V.; OLIVEIRA, D. de. Crescimento e desenvolvimento do feijoeiro sob diferentes regimes térmicos e hídricos. In: CONGRESSO BRASILEIRO DE AGROMETEOROLOGIA, 10., Piracicaba, 1997. Anais. Piracicaba: Sociedade Brasileira de Agrometeorologia, 1997 . p.659-661.

FEITOSA, C. T.; RONZELli, P. J.; ALMEIDA, L. D'A. de; VEIGA, A. de A.; HIROCE, R.; JORGE, J. P. N. Adubação NP para o feijoeiro (Phaseolus vulgaris L.) na presença e na ausência de calcário. Revista Brasileira de Ciência do Solo, v.4, n. 3, p. 156-159, 1980.

FERNÁNDEZ ; F. GEPTS, P.; LÓPEZ, M. Etapas de desarrollo de la planta de frijol común. Guía de estudio para ser usada como complemento de la unidad audiotutorial sobre el mismo tema. Cali, Colômbia,. 1982. 26 p.

FIBGE - Fundação Instituto Brasileiro de Geografia e Estatistica. Levantamento Sistemático da Produção Agrícola. Rio de Janeiro, 1990-96. 
FISCHER, V.J.; WEAVER, C.K. Flowering, pod set, and pod retention of lima bean in response to high temperature, humidity and soil moisture. Journal of American Society of Horticultural Science, v. 99, n. 5, p. 448-450, 1974.

FOLLETT, R.F.; ALLMARAS, R.R.; REICHMAN, G.A. Distribution of corn roots in sandy soil with a declining water table. Agronomy Journal, v.66, p. 288-292, 1974.

FRANCO, M; INFORZATO, R. O sistema radicular do cafeeiro nos principais tipos de solo do estado de São Paulo. Bragantia, v.6, n. 9, p. 443-448, 1946.

FRANCO, A. A.; SOUTO, S. M. Contribuição da fixação biológica de $\mathrm{N}_{2}$ na adubação verde. Adubação verde no Brasil. Fundação Cargill, Campinas, 1984. p. 199-215.

FUJIWARA, M.; KURACHI, S. A. H.; ARRUDA, F. B.; PIRES, R. C. de M.; SAKAI, E. A técnica de estudo de raízes pelo método do trado. Campinas, Instituto Agronômico, 1994. 9 p. (Boletim Técnico, 153).

GABELMAN, W. H.; WILLIAMS, D.D.F. Developmental studies with irrigated sanp beans. Research Bulletin of Wisconsin Agricultural Experimental Station. 1960. $221 \mathrm{p}$.

GALLO, J. R.; MIYASAKA, S. Composição química do feijoeiro e absorção de elementos nutritivos, do florescimento à maturação. Bragantia, v. 20, p. 867-884, 1961.

GALLO, P. B.; LAVORENTI, A.; SAWASAKI, E.; HIROCE, R.; MASCARENHAS, H. A. A. Efeito de cultivos anteriores de soja na produção e no teor de nitrogênio das folhas e dos grãos de milho. Revista Brasileira de Ciência do Solo, v. 5, p. 64-67, 1981. 
GARRIDO, M. A. T.; PURCINO, J. R. C.; LIMA, C. A. S. Efeito de diferentes niveis de umidade do solo sobre o rendimento do feijoeiro comum, na região norte de Minas Gerais. In: Empresa de Pesquisa Agropecuária de Minas Gerais, Belo Horizonte, Minas Gerais. Projeto Feijão, Belo Horizonte, 1978. p. 28-30. (Relatório 76/77)

GARRIDO, M.A.T; PURCINO, J.R.C.; LIMA, C.A.S. Efeitos de diferentes regimes de irrigação sobre o rendimento do feijoeiro na região Norte de Minas Gerais. In: EPAMIG. Projeto feijão. Belo Horizonte, 1979. p. 27-29. (relatório 77/78).

GEPTS, P.; FERNÁNDEZ, F. Etapas de desarrollo de la planta de frijol comum (Phaseolus vulgaris L.). Cali, Colombia, CIAT, 1982.10 p. (mimeografado)

GLINSKI, J.; LIPIEC, J. Soil physical conditions and plant roots. Boca Raton: CRC Press, $1990.250 \mathrm{p}$.

GOEDERT, W.J.; RITCHEY, K.D.; SANZONOWICZ, C. Desenvolvimento radicular do capim-andropogon e sua relação com o teor de cálcio no perfil do solo. Revista Brasileira de Ciência do Solo, v.9 p. 89-91, 1985.

GRANT, R.F. Simulation model of soil compaction and root growth. Plant and Soil, v. 150, p. $15-24,1993$

GREACEN, E.L. Root response to soil mechanical properties. CONGRESS OF THE ISSS, 13, Hamburg, 1986. Congress of the ISSS, 13. Hamburg, v. 5, 1986. p. 20-47.

GROHMANN, F.; RAIJ, B. van. Influência dos métodos de dispersão da argila do solo. In: CONGRESSO BRASILEIRO DE CIÊNCIA DO SOLO, 14. Santa Maria, 1973. Anais. Santa Maria, Sociedade Brasileira de Ciência do Solo, 1974. p.123-132. 
GROHMANN, F.; QUEIROZ NETO, J. A. Efeito da compactação artificial de dois solos limo-argiloso sobre a penetração das raizes de arroz. Bragantia, v. 25, n. 38 , p. 421-431, 1966.

GUIDOLIN, A.F; MEROTTO JÚNIOR, A.; ENDER, M. Compensação do menor desenvolvimento de feijão em época tardia através do arranjo e população de plantas. In: REUNIÃO NACIONAL DE PESQUISA DE FEIJÃO, 5., Goiânia, 1996. Anais. Goiânia: EMBRAPA-CNPAF-APA, 1996. v.1. p.453-455 (Documentos, 69).

GUTMARÃES, C.M. Características morfo-fisiológicas do feijoeiro (Phaseolus vulgaris L.) relacionadas com a resistência à seca. Campinas, 1992. 131 p. Tese (Doutorado) Instituto de Biologia, UNICAMP.

GUIMARÃES, C. M.; ZIMMERMANN, M.J. de O. Deficiência hídrica em feijão. In: REUNION DE TRABAJO SOBRER MEJORAMIENTO DE FRIJOL EN BRASIL CON ENFASIS EN TOLERANCIA A SEQUIA, Cali,1985. Anais. Cali: CIAT, 1985, p.15-28.

GUIMARÃES, C.M.; BRUNINI, O.; STONE, L.F. Adaptação do feijoeiro (Phaseolus vulgaris L.) à seca. I. Densidade e eficiência radicular. Pesquisa Agropecuária Brasileira, v. 31, n. 6, p. 393-399, 1996.

GUIMARÃES, M.F.; BALBINO, L.C.; MEDINA, C.C.; RIBEIRO, A.M.A.; RALISH, R; TAVARES FILHO, J. A metodologia do perfil cultural e o enraizamento. In: CONGRESSO BRASILEIRO DE CIÊNCIA DO SOLO, 26., Rio de Janeiro, 1997. Resumos expandidos. Rio de Janeiro, 1997a. (Conferência)

GUIMARÃES, M.F.; JORGE, L.C.A.; De MARIA, I.C.;TAVARES FILHO, J.; BICUDO, S.J.; CRESTANA, S. Três metodologias de avaliação de raizes: descrição, limitações e vantagens. In: CRUVINEL, P.E.; CRESTANA, S.; MARTIN NETO, L.; COLNAGO, L.A.; MATTOSO, L.H.C. (Coord.). SIMPÓSIO NACIONAL DE INSTRUMENTAÇÃO AGROPECUÁRIA, 1., São Carlos, 1996. Anais. São Carlos, CNPDIA/EMBRAPA, 1997b. p.295-304. 
HAAG, H. P.; MALAVOLTA, E.; BLANCO, H. G. Absorção de nutrientes pela cultura do feijoeiro. Bragantia, v. 26, p. 381-392, 1967.

HALTERLEIN, A. J. Bean. In: TEARE, I. D. \& PEET, M.M., ed. Crop water relations. New York, John Wiley,1983. cap. 5, p.157-85.

HARRIS, R.F.; CHESTERS, G.; ALLEN, O.N. Dynamics of soil aggregation. Advance Agronomy, v. 18, p. 107-169, 1966.

HEINRICHS, R. Ervilhaca e aveia preta cultivadas simultaneamente como adubo verde e sua influência no rendimento do milho. Piracicaba, 1996. 65 p. Dissertação (M.S.) Escola Superior de Agricultura "Luiz de Queiroz", Universidade de São Paulo.

HENCKLAIN, J.C.; GUIMARÃES, M.F.; VIEIRA, M.J.; MEDINA, C.C. Efeitos do preparo do solo no desenvolvimento radicular. In: CONGRESSO BRASILEIRO PARA UMA AGRICULTURA SUSTENTÁVEL, 1., Ponta Grossa, 1996. Resumos expandidos. Ponta Grossa, 1996. p.103-105.

HESTERMAN, O. B.; SHEAFFER, C. C.; BARNES, D. K.; LUESCHEN, W. E.; FORD, J. H. Alfafa dry matter and nitrogen production, and fertilizer nitrogen response in legume-corn rotations. Agronomy Journal, v. 78, n. 1, p. 19-23, 1986.

HIROCE, R.; GALLO, J. R.; MIYASAKA, S. Análise foliar de feijoeiro. I - Nutrição nitrogenada e potássica. Bragantia, v. 28, p. I-VIII, 1969. (Nota, 1)

HIROCE, R.; GALLO, J. R.; MASCARENHAS, H. A. A. Análise foliar em feijoeiro. IIDiagnose da adubação fosfatada. Bragantia, v. 29, p. VII-XII, 1970. (Nota, 2) 
HULUGALLE, N.R. ; LAL, R. Root growth of soybean (Glycine max L. Merr.) and cowpea (Vigna unguiculata Walp.) on a hydromorfic toposequence in Western Nigeria. Plant and Soil, v. 91, p. 195-208, 1986.

HUNT, R. Growth analysis of individual plants. In: ARNOLD, E. (ed.), Plant growth analysis. Southhampton:Camelot Press, 1978. p.26-28 (Studies in Biology, 6).

IGARASHI, Y.; NAKAGAWA, S.; YAMAMOTO, H. Evaluation of dry matter production and nutrient - element accumulation of several summer-growing green manure crops. In: INTERNATIONAL PLANT NUTRITION COLLOQUIUM, 13, Tokyo, 1997. Proceedings. Tokyo: Kluwer Academic Publishers, 1997. p.:647-648.

INFORZATO, R. Estudo do sistema radicular de Tephrosia candida D.C. Bragantia, v. 7, p. 49-54, 1974.

INFORZATO, R; MIYASAKA, S. Sistema radicular do feijoeiro em dois tipos de solos do Estado de São Paulo. Bragantia, v. 22, n. 2, p. 477-481, 1963.

INFORZATO, R; TELLA, R. Sistema radicular do amendoim. Bragantia, v. 19, p. CXIX-CXXIII, 1960. (Nota, 24)

INFORZATO, R.; GUIMARÃES, G.; BORGONOVI, M. Desenvolvimento do sistema radicular do arroz e do feijoeiro em duas séries de solo do Vale do Paraíba. Bragantia, v. 23, n. 30, p. 365-369, 1964.

INSTITUTO DE ECONOMIA AGRÍCOLA/IEA. Levantamento ao nivel de produto Feijão. São Paulo. Definitivo, 1992-1993. 
JARA, R. J. C. Evaluación de la temperatura de la cubierta vegetal y otros parámetros biofisicos en frejol negro (Phaseolus vulgaris L.). Chillán, 1985. 133 p. Tese (M.S.) Universidad de Concepción, Chile.

JOFFE, J. S. Green manuring view by a pedologist. Advance in Agronomy. New York: Academic Press Inc. 1955.

JONES, L.H. Adaptative responses to temperature in dwarf french beans, Phaseolus vulgaris L. Annals of Botany, v. 35, p. 581-596, 1971.

JUNG, G. A., ed. Crop tolerance to suboptimal land conditions. Madison, American Society of Agronomy, 1978. 343 p. (Special publication, 32)

JUO, A. S. R,; LAL, R. Nutrient profile in a tropical Alfisol under conventional and notill systems. Soil Science, v. 127, p. 168-173, 1979.

KIEHL, J.E.Contribuição para o estudo da poda e da decomposição de adubos verdes. Piracicaba, 1960. 113 p. Tese (Doutorado) - Escola Superior de Agricultura 'Luiz de Queiroz", Universidade de São Paulo.

KOFFLER, N. F. A profundidade do sistema radicular e o suprimento de água às plantas no cerrado. Informações Agronômicas, v.33, p.1-4, 1986.

KORNELIUS, E.; SOBRAL, L.F.; GOMES, J. de C.; RODRIGUES, E. M. Efeitos de doses de nitrogênio e fósforo na produção de feijão. In: CONGRESSO BRASILEIRO DE CIÊNCIA DO SOLO, 15., Campinas, 1976. Anais. Campinas: Sociedade Brasileira de Ciência do Solo, 1976. p. 203-205.

KRAMER, P. J. Plant and soil water relationships: A modern synthesis. New York: McGraw-Hill. 538 p.,1969. 
KRANZ, W.M.; PARRA, M.S.; BIANCHINI, A. Associação de sistemas de cultivos para viabilização da cultura do feijoeiro em regiões afetadas pelo mosaico dourado do Paraná. In: REUNIÃo NACIONAL DE PESQUISA DE FEIJÃO, 5., Goiânia, 1996. Anais. Goiânia: EMBRAPA-CNPAF-APA, 1966. v.1. p.432-434 (Embrapa-CNPAF. Documentos, 69).

KRONSTAD, W. E.; McCUISTION, W. L.; SWEARINGIN, M. L.; QUALSET, C. O. Crop selection for specific residue management systems. In: Oschwald, W. R.; Stelly, M.; Kral, D. M.; Nauslef, J. H. (Ed.). Crop residues management systems. Madison, ASA/CSSA/SSSA, 1978. cap. 12, p. 207-17. (ASA Special Publication, 31)

KÛET, J;; MARSHALL, J. K. Assessment of leaf area and other assimilating plant surfaces. In: SESTÁK, Z.; CATSKY, J.; JARVIS, P.G. (Ed.). Plant Photosynthetic Production - manual of methods. The Hague: N. V. Publishers. 1971. cap. 14, p. $517-555$.

LAING, D. R. ; JONES, P. G.; DAVIS, H. C. Common bean (Phaseolus vulgaris L.). In: GOLDSWORTHY, P. R. \& FISHER, N. M., ed. The Physiology of tropical field crops. New York: Wiley-Interscience, 1984. cap. 9, p. 305-49.

LAL, R. Influence of tillage methods and residue mulches on soil structure and infiltration rates. In: LAL, R.; GREENLAND, eds. Soil physical properties and crop production in the tropics. Chichester: John Whiley and Sons, 1979. $551 \mathrm{p}$.

LEMOS, L.B. Avaliação do comportamento de genótipos de feijão (Phaseolus vulgaris L.) cultivados na época de inverno em Jaboticabal - SP. Jaboticabal, 1995, $124 \mathrm{p}$. Dissertação (M.S.) - Faculdade de Ciências Agrárias e Veterinárias, Universidade Estadual Paulista "Julio de Mesquita Filho". 
LOPES, N.F; MIGLIORANZA, É. Variação dos componentes da biomassa nos diversos órgãos e durante o ciclo de vida de Phaseolus vulgaris $\mathrm{L}$. submetidos a dois regimes hídricos. In: REUNIÃO NACIONAL DE PESQUISA DE FEIJÃO, 4., Londrina, 1993. Resumos. Londrina:IAPAR, 1993. p.25.

LORENZI, H. Considerações sobre plantas daninhas no plantio direto. In: VIDALTORRADO, P.; ALOISI, R.R. (Coord.). Plantio Direto no Brasil . Campinas: Fundação Cargill, 1984. p. 13-46.

LUCAS, O; MILBOURN, G.M.; WHITFORD, P.N. The translocation of ${ }^{14} \mathrm{C}$ photosynthate from leaves and pods in Phaseolus vulgaris L. Annals of Applied Biology, v. 83, p. 285-290, 1976.

LUNIN, J. GALLATIN, M. R.; BATCHELDER, A. R. Interactive effects of basic saturation and exchangeable sodium on the growth and cation composition of beans. Soil Science, v. 97, p. 25-33, 1964a.

LUNIN, J. GALLATIN, M. R.; BATCHELDER, A. R. Interactive effects of soil fertility and salinity on the growth and composition of beans. American Society for Horticultural Science. Proceedings. v. 85, p. 350-360, 1964b.

MACK, H. J.; SINGH, J. N. Effect of high temperature on yield and carboydrate composition of bush snap bean. Journal of the American Society for Horticultural Science, v. 94, p.60-62, 1969.

MACKAY, A. D.; BARBER, S. A. Soil moisture effects on root growth and phosphorus uptake by corn. Agronomy Journal, v. 77, n. 4, p. 519-523, 1985.

MAGAlHÃES, A.A. de; MILLAR, A.A. Efeito do déficit de água no período reprodutivo sobre a produção do feijão. Pesquisa Agropecuária Brasileira, v. 13, n. 2, p. 55-60, 1978. 
MAGALHÃES, A. C.; CARELLI, M. L. Germinação de sementes de feijão (Phaseolus vulgaris L.) sob condições variadas de pressão osmótica. Bragantia, v. 31, n.32, p. 19-26, 1972.

MAGALHÃES, A. C.; MONTOJOS, J. C. Effect of solar radiation on the growth parameters and yield of two varieties of common beans (Phaseolus vulgaris L.). Turrialba, v. 21, p. 165-168, 1971.

MAGALHÃES, A.C.; MILLAR, A.A.;CHOUDHURY, E.N. Efeito do déficit fenológico de água sobre a produção de feijão. Turrialba, v. 29, n. 4, p. 269-273, 1979.

MAGALHÃES, A. C.; MONTOJOS, J. C.; MIYASAKA, S. Effect of dry organic matter on growth and yield of beans (Phaseolus vilgaris L.). Experimental Agriculture, v. 7, p. 137-143, 1971.

MALAVOLTA, E. Arroz e Feijão - Grandes exigências. In: Guia Rural 1968/1969, São Paulo, 1969, p. 10-13.

MALAVOLTA , E. Leguminosas - feijões, soja. In: Manual de calagem e adubação das principais culturas. Editora Agronômica Ceres Ltda. São Paulo, 1987, p.102150 .

MALAVOLTA, E. Nutrição e adubação do feijoeiro. CENA-USP, Piracicaba.63 p.1995.

MALAVOLTA, E.; DAMIÃO FILHO, C.F.; VOLPE, C.A.; MACHADO JÚNIOR, G.R.; VELIJO, L.M.S.; ROSA, P.R.F.; LAURENTIZ, S. Deficiência e excessos minerais no feijoeiro (Phaseolus vulgaris L., cv Carioca). Anais da Escola Superior de Agricultura "Luiz de Queiroz", v. 32, n. 2, p. 701-718, 1980.

MARTIN, M. I.; TEIXEIRA, N. T.; COBRA NETTO, A. Comportamento dos micronutrientes e do nitrogênio total e solúvel em feijoeiro (Phaseolus vulgaris L.). Revista Livroceres, v. 1, n. 2, p. 5-6, 1976. 
MARTIN, N. B.; SANTOS, Z. A. P. S. \& ASSUMPÇÃO, R. Análise econômica da utilização da adubação verde nas culturas de algodão e soja em rotação com milho e amendoim. In: Adubação verde no Brasil. Campinas, Fundação Cargill, 1984. p.133160.

MASCARENHAS, H.A.A; TANAKA, R.T. Rotação de Culturas. In: WUTKE, E.B.; BULISANI, E.A.; MASCARENHAS, H.A.A. (Coord). Curso sobre adubação verde no Instituto Agronômico,1., Campinas, 1993. p.71-86. (Documentos IAC, 35)

MASCARENHAS, H. A. A.; MIYASAKA, S.; ALMEIDA, L. D.A. de. Adubação verde do feijoeiro "da seca" com ervilha-de-vaca. Bragantia, v. 26, tomo único, p. XXXVII-XL, 1967a. (Nota, 8)

MASCARENHAS, H. A. A.; MIYASAKA, S.; LOVADINI, L. A. C.; FREIRE, E. S.; TEÓFILO SOBRINHO, J.; CRUZ, L. P.; NERY, C.; ANDRADE, F. G. de. Efeito da adubação verde do feijoeiro "da seca" com Crotalaria juncea L. empregando-se toda a vegetação ou retirando-se do campo as hastes despojadas de suas folhas. Bragantia, v. 26, tomo único, p. 219-234, 1967b.

MELLO, R. de. Análise energética de agroecossistemas: o caso de Santa Catarina. Florianópolis, 1986. 139 p. Tese (M.S.)- Universidade Federal de Santa Catarina.

MELLO, W.M.P.de. Desenvolvimento do sistema radicular do milho sob três métodos de preparo do solo. Porto Alegre, 1991. 121 p. Dissertação (M.S.) - Faculdade de Agronomia da Universidade Federal do Rio Grande do Sul.

MENEGARIO, A. Cultura do feijão. Campinas, Secretaria de Agricultura, Divisão de Assistência Técnica Especializada, 1964. 139 p. (Série Instruções Técnicas, 9). 
MEROLA, R. de C. Plantio direto: principais problemas. In: FANCELLI, A.L. \& DOURADO-NETO, D. (Coord.). Tecnologia da produção do feijão irrigado. Piracicaba: ESALQ/USP, Departamento de Agricultura, 1997. p.153-158.

MIRREH, H.F.; KETCHESON, J.W. Influence of soil bulk density and matric pressure on soil resistance to penetration. Canadian Journal of Soil Science, v. 53, p. 383$388,1972$.

MIYASAKA, S.; FREIRE, E. S.; MASCARENHAS, H. A. A.; IGUE, T. Adubação verde, calagem e adubação mineral do feijoeiro em solo com vegetação de "cerrado". Bragantia, v. 24, n. 26, p. $321-338,1965$.

MIYASAKA, S.; CAMARGO, A. P. de; INFORZATO, R.; IGUE, T. Efeitos da cobertura e da incorporação ao solo, imediatamente antes do plantio, de diferentes formas de matéria orgânica não decomposta na cultura do feijoeiro. Bragantia, v. 25, n. 32, p. $349-363,1966 a$.

MIYASAKA, S.; FREIRE, E. S.; ALVES, S.; ROCHA, T. R. Adubação mineral do feijoeiro. III. Efeitos de N, P, K, da calagem e de uma mistura de enxofre e micronutrientes, em solo massapê-salmourão. Bragantia, v. 25 , n. 15 , p. 179-188, $1966 \mathrm{~b}$.

MIYASAKA, S.; FREIRE, E. S.; IGUE, T.; CAMPANA, M. Adubação mineral do feijoeiro. II. Efeitos de N, P, K, da calagem e de uma mistura de enxofre e micronutrientes em terra-roxa-misturada. Bragantia, v. 25, n. 13, p. 145-159, 1966c.

MIYASAKA, S.; FREIRE, E.S.; MASCARENHAS, H.A.A.; NERY, C; CAMPANA, M.; SORDI, G. de. Efeito da adubação verde com uma gramínea e quatro leguminosas sobre a produção do feijão "da seca" em terra roxa misturada. Bragantia, v. 25, p. 277-289, 1966d. 
MIYASAKA, S.; FREIRE, E.S.; IGUE, T.; TEÓFILO SOBRINHO, J.; ALMEIDA, L. D. A. de. Respostas do feijoeiro à aplicação de diversos tipos de matéria orgânica não decomposta, na presença de adubações minerais com P, PK, NP ou NPK. Bragantia, v. 26, tomo único, p. 335-344, 1967.

MIYASAWA, M.; ZOCOLER, D.C.; BLOCK, M. F. M. Determination of Ca, Mg, K, $\mathrm{Mn}, \mathrm{Cu}, \mathrm{Zn}, \mathrm{Fe}$ and $\mathrm{P}$ in coffee, soybean, corn, sunflower, and pasture grass leaf tissue by a $\mathrm{HCl}^{-}$extraction method. Soil Science Plant Analysis, v.15, n.2, p.141-147, 1984.

MIYASAWA, M.; PAVAN, M.A.; CALEGARI, A. Efeito de material vegetal na acidez do solo. Revista Brasileira de Ciência do Solo, v. 17, n. 3, p. 411-416, 1993.

MONEGAT, C. Plantas de cobertura do solo: características e manejo em pequenas propriedades. Chapecó: Ed. do Autor, 1991. 337 p.

MONTEITH, J. L. Light distribution and photosynthesis in field crops. Annual Botany, v. 29, p. $17-37,1965$

MONTEITH, J. L. Assessment of maximum growth rates for $C_{3}$ and $C_{4}$ crops. Experimental Agriculture, v. 14, p. 1-5, 1978.

MONTOJOS, J. C.; MAGALHÃES, A. C. Growth analysis of dry beans (Phaseolus vulgaris $\mathrm{L}$. var. Pintado) under varying conditions of solar radiation and nitrogen application. Plant and Soil, v. 35, p. 217-223, 1971.

MORAES, M.H.; BENEZ, S.H.; LIBARDI, P.L. Influência de camadas compactadas de subsuperficie no desenvolvimento do sistema radicular de plantas de soja (Glycine max (L.) Merrill). Científica, v. 19, n. 1, p. 195-206, 1991. 
MOREIRA, J.A.A.; STONE, L.F. Manejo de solo-planta e avaliação sócio-econômica dos sistemas agrícolas irrigados por aspersão na região dos cerrados. Goiânia: EMBRAPA-CNPAF,1995.1 v. (EMBRAPA. Projeto 04.0.95.273.06; em andamento).

MUZILLI, O. Manejo da fertilidade do solo. In: PLANTIO DIRETO NO ESTADO DO PARANÁ. Londrina, Fundação Instituto Agronômico do Paraná, 1981. p. 43-53 (Circular IAPAR, 23).

MUZILLI, O. Influência do sistema de plantio direto, comparado ao convencional, sobre a fertilidade da camada arável do solo. Revista Brasileira de Ciência do Solo, v. 7, p. $95-102,1983$

NEERGAARD, P. Seed crop management. In: NEERGARD, P. (Ed). Seed Pathology. London: Macmillan Press, 1979. p. 529-73.

NEME, N. A. Leguminosas para adubos verdes e forragens. Campinas: Instituto Agronômico, 1940. 28 p. (Boletim, 109).

NOGUEIRA, S. dos S. S. Ciclo biológico, características fisiológicas, produção e composição química da semente dos cultivares de soja (Glycine max (L.) Merril) UFV-1 e IAC-7 em diversas épocas de semeadura. Piracicaba, 1983, 96 p. Tese (Doutorado) - Escola Superior de Agricultura "Luiz de Queiroz", Universidade de São Paulo.

NOGUEIRA, C. S. P. Comportamento de genótipos de feijão de cor (Phaseolus vulgaris L.) sob condições de cultura irrigada na Região de Jaboticabal-SP. Jaboticabal, 1990. 43 p. Monografia (Graduação) - Faculdade de Ciências Agrárias e Veterinárias, Universidade Estadual Paulista "Julio de Mesquita Filho". 
NOGUEIRA, S. dos S. S.; MANFREDINI, S. Influência da compactação do solo no desenvolvimento da soja. Pesquisa Agropecuária Brasileira, v. 18, n.9, p. 973-976, 1983.

NOORDWIJK, M. van. Root ecology and its practical application. INTERNATIONAL SYMPOSIUM GUMPENSTEIN, 1982. Bundesanstalt Gumpenstein, A-8952, Irdning, 1983. p. 207-226.

OLIVEIRA, E. de. Efeito da Crotalaria juncea Linn. na eficiência agronômica, econômica e energética de culturas em sucessão sob plantio direto. Piracicaba, 1996. 95 p. Tese (Doutorado) - Escola Superior de Agricultura "Luiz de Queiroz", Universidade de São Paulo.

OLIVEIRA, J. B. de; MENK, J. R. F. Latossolos roxos do Estado de São Paulo. Campinas: Instituto Agronômico, 1984. 132 p.

OLIVEIRA, J. B. de; MONIZ, A. C. Levantamento pedológico detalhado da Estação Experimental de Ribeirão Preto, São Paulo. Bragantia, v. 34, n. 2, p. 59-113. 1975.

OLIVEIRA, I. P.; THUNG, M. D. T. Nutrição mineral. In: ZIMMERMANN, M. J. de O.; ROCHA, M. ; YAMADA, T. (Eds.). Cultura do feijoeiro: fatores que afetam a produtividade. Piracicaba, POTAFÓS, 1988. p. 175-259.

OLIVEIRA, E.F. de; BAIRRÃO, J.F.M.; BALBINO, L.C.; GAUDÊNCIO, C. de A. Efeito da rotação de culturas em plantio direto nas características fisicas de Latossolo roxo distrófico. In: CONGRESSO BRASILEIRO E ENCONTRO NACIONAL DE PESQUISA SOBRE CONSERVAÇÃO DO SOLO, 8., Londrina, 1990. Resumos. Londrina: SBCS/SEAB/IAPAR, 1990. p. 90. 
OLIVEIRA, I.P. de; KLUTHCOUSKI, J.; CARVALHO, J.R.P. de Efeitos de macro e micronutrientes na cultura do feijão (Phaseolus vulgaris L.) em latossolo vermelhoescuro. In: REUNIÃO NACIONAL DE PESQUISA DE FEIJÃO, 1., Goiânia, 1982. Anais. Goiânia, EMBRAPA-CNPAF, 1982. p.214-217.

OLIVEIRA, I. P.de; ARAÚJO, R. S.; DUTRA, L. G. Nutrição mineral e fixação biológica de nitrogênio. In: ARAÚJO, R. S.; RAVA, C. A.; STONE, L. F; ZIMMERMANN, M. J. de O. (Coord.). Cultura do Feijoeiro Comum no Brasil. Piracicaba, POTAFOS, 1996. p.169-221.

OSAKI, M; SHINANO, T; MATSUMOTO, M; ZHENG, T.; TADANO, T. A rootshoot interaction hypothesis for high productivity of fiels crops. In: ANDO, $\mathrm{T}$,; FUJITA, K.; MAE, T.; MATSUMOTO, H.; MORI, S.; SEKIYA, J.(Eds.). In: INTERNATIONAL PLANT NUTRITION COLLOQUIUM, 13., Tokyo, 1997. Proceedings. Tokyo: Kluwer Academic Publishers, 1997. p.:669-674.

OSPINA, O.H.F. Morfologia de la planta del frijol común (Phaseolus vulgaris L.). Cali: CIAT, $2^{\mathrm{a}}$ ed., 1981. 50 p. (Guía de estudio, Serie 04SB-09.01).

OTANI, T.; Ae, N. The exudation of organic acids by pigeonpea roots for solubilizing iron-and aluminum-bound phosphorus. In: ANDO, T.; FUJTA, K.; MAE, T.; MATSUMOTO, H.; MORI, S.; SEKIYA, J. (Eds.). In: INTERNATIONAL PLANT NUTRITION COLLOQUIUM, 13., Tokyo, 1997. Proceedings. Tokyo: Kluwer Academic Publishers, 1997. p.:325-326.

PANDEY, R.K.; HERRERA, W.A.T.; VILLEPAS, A.N.; PENDLETON, J.W. Drought response of grain legumes under irrigation gradient: III. Plant growth. Agronomy Journal, v. 76, p. 557-560, May-june 1984. 
PAREDES, C.M.; FRANCE, A.I.; BASCUR, B.G. Desarrollo, evaluación y uso del germoplasma de frijol común en Chile. In: CIAT (Centro Internacional de Agricultura Tropical). 1989. Progreso en la investigación y producción del frijol común (Phaseolus vulgaris L.). Advances in bean (Phaseolus vulgaris L.) research and production. Cali, 1989. p.:333-343.

PATRICK, Z. A.; TOUSSON, T. A.; KOCH, L. W. Effect of crop-residue decomposition products on plant roots. Annual Review of Phytopathology, v. 2, p.267-292, 1964.

PEARSON, R.W. Significance of rooting pattern to crop production and some problems of root research. In: CARSON, E.W. (Ed.). The plant root and its environment. Charlotesville: University Press of Virginia, 1974. cap. 10: 247-270.

PEDÓ, F. Rendimento e distribuição de raizes de seis espécies de plantas em dois níveis de compactação do solo. Porto Alegre, 1986. 92 p. Dissertação (M.S.) - Faculdade de Agronomia da Universidade Federal do Rio Grande do Sul.

PELOSO, M.J. del; SILVEIRA, P.M. da; SILVA, C.C. da; MOREIRA, J.A.A. Cultivo irrigado em terras altas. In: ARAÚJO, R.S.; RAVA, C.A.; STONE, L.F.; ZIMMERMANN, M.J.de O. (Coord.). Cultura do Feijoeiro Comum no Brasil. Piracicaba, POTAFOS, 1996. p. 571-588.

PEREIRA, A. R.; MACHADO, E. C. Análise quantitativa do crescimento de comunidades vegetais. Campinas: Instituto Agronômico, 1987. 33 p. (Boletim técnico, 114)

PHILLIPS, R.E.; KIRKHAN, D. Mechanical impedance and corn seedling root growth. Soil Science Society of America Proceedings, v. 26, p. 319-322, 1962. 
PIGGOTT, T. J. Vegetable cops. In: REUTER, D. J.; ROBINSON, J. B. (Eds.). Plant analysis - an interpretation manual. Melbourne: Inkata Press, p. 38-99. 1986.

PIMENTEL-GOMES, F. P. A estatística moderna na pesquisa agropecuária Piracicaba, POTAFOS, 1984. $160 \mathrm{p}$.

PINTO, C. F. J. A.; VASCONCELOS, C. A. Efeito de sistemas de rotação de culturas nas densidades populacionais de Pratylenchus spp. parasitas do milho. Nematologia Brasileira, v. 16, n. 1/2, p. 81, 1992.

PINZAN , N. R. ; BULISANI, E. A.; BERTI, A. J. Feijão - zoneamento ecológico e épocas de semeadura para o Estado de São Paulo. Campinas: Coordenadoria de Assistência Técnica Integral - CATI, 1994. 19 p. ilus. (Boletim Técnico, 218)

PIRES, R.C de M.; ARRUDA, F.B.; FUJIWARA, M.; SAKAI, E.; BORTOLETTO, N. Profundidade do sistema radicular das culturas de feijão e trigo sob pivô central. Bragantia, v. 50, n. 1, p. 153-62, 1991.

POMPEU, A.S. Melhoramento do Feijoeiro. In: BULISANI, E.A. (Coord.). Feijão: fatores de produção e qualidade. Campinas: Fundação Cargill, 1987. p. 1-28.

PONAMPERUMA, F. N. The chemistry of submerged soils in relation to the growth and yield of rice. Ithaca. 1955. 208 p. Tese (Doutorado) - Cornell University.

PORTAS, C. A. Acêrca do sistema radical de algumas culturas horticolas. Luanda: Universidade de Luanda, 1970. $241 \mathrm{p}$.

PORTES, T. de A. Ecofisiologia. In: ARAÚJO, R.S.; RAVA,C.A.; STONE, L.F.; ZIMMERMANN, M.J.de O. (Coord.). Cultura do Feijoeiro Comum no Brasil. Piracicaba: POTAFOS, 1996. p.101-137. 
PORTES, T. de A.; CARVALHO, J. R. P. de. Área foliar, radiação solar, temperatura do ar e rendimentos em consorciação e em monocultivo de diferentes cultivares de milho e feijão. Pesquisa Agropecuária Brasileira, v. 18, n. 7, p. 755-762, 1983.

PORTES, T. de A.; SILVEIRA, P. M. da; KLUTHCOUSKI, J. The effect of artificial shading on the growth and grain yield of beans (Phaseolus vulgaris L.). Annual Report of the Bean Improvement Cooperative, v. 23, p. 103, 1980.

RAIJ, B. van; QUAGGIO, J. A.; CANTARELLA, H.; FERREIRA, M. E.; LOPES, A. S.; BATAGLIA, O. C. Análise química de solos para fins de fertilidade. Campinas: Fundação Cargill, 1987. 170 p.

RAIJ, B. van; SILVA, N. M. da; BATAGLIA, O. C.; QUAGGIO, J. A.; HIROCE, R.; CANTARELLA, H.; BELLINAZZI JÚNIOR, R.; DECHEN, A. R.; TRANI, P. E. Recomendações de adubação e calagem para o Estado de São Paulo. Campinas: Instituto Agronômico, 1985. 107 p. (Boletim técnico, 100).

RAIJ, B. van; QUAGGIO, J.A.; CANTARELLA, H.; ABREU, C.A. de. Recomendações de adubação e calagem para o Estado de São Paulo. In: RAIJ, B.van; CANTARELlA, H.; QUAGGIO, J.A.; FURLANI, A.M.C. (Eds.). Recomendações de adubação e calagem para o Estado de São Paulo, 2.ed. Campinas: Instituto Agronômico \& Fundação IAC, 1996. cap. 1-4, p.1-13.

RAPER, D. C.; BARBER, S. A. Rooting systems of soybean. I. Differences in root morphology among varieties. Agronomy Journal, v. 62, p. 581-584, 1970.

REDDY, K. C.; SOFFES, A. R.; PRINE, G. M. DUNN, R. A. Tropical legumes for green manure. II. Nematode populations and their effects on succeeding crop yields. Agronomy Journal, v. 78, n. 1, p. 5-10, 1986. 
REICHARDT, K. ; LIBARDI, P. L.; SANTOS, J. M. dos. An analysis of soil-water movement in the field: II. Water balance in a snap bean crop. Piracicaba: CENA, 1974. 19 p. (Boletim Cientifico, BC-022).

RESENDE, M.; HENDERSON, D.W; FERERES, E. Freqüência de irrigação, desenvolvimento e produção do feijão kidney. Pesquisa Agropecuária Brasileira, v. 16, n. 3 , p. $363-370,1981$.

RITCHEY, K. D.; SILVA, J. E.; SOUSA, D. M. G. Relação entre teor de cálcio no solo e desenvolvimento de raizes avaliado por um método biológico. Revista Brasileira de Ciência do Solo, v. 7, p. 269-275, 1983.

RODER, W.; MASON, S. C.; CLEGG, M. D.; KNIEP, K. R. Crop root distribution as influenced by grain sorghum-soybean rotation and fertilization. Soil Science Society of American Journal, v. 53, n. 5, p. 1464-1470, 1989.

ROSA, A. S. Rotação de culturas. In: SIMPÓSIO DE CONSERVAÇÃO DE SOLOS DO Planalto, 2., Passo Fundo, 1980. Anais. Passo Fundo: Universidade de Passo Fundo, Faculdade de Agronomia, 1980. p.23-31.

ROSOLEM, C. A. Nutrição e adubação do feijoeiro. Piracicaba: POTAFÓS, 1987. 93 p. (Boletim técnico, 8).

ROSOLEM, C. Calagem e adubação mineral. In: ARAÚJO, R.S.; RAVA, C.A.; STONE, L.F.; ZIMMERMANN, M.J. de O. (Coord.). Cultura do feijoeiro comum no Brasil. Piracicaba: POTAFOS, 1996. Seção III. p. 353-416.

ROSOLEM, C. A.; MARUBAYASHI, O. M. Seja o doutor do seu feijoeiro. Informações Agronômicas, n. 68. 16 p. 1994. (Encarte) 
ROTH, C. H.; MEYER, B. Infiltrabilidade de um latossolo roxo distrófico durante o período vegetativo da soja sob o preparo convencional, escarificação e plantio direto. In: CONGRESSO BRASILEIRO DE CIÊNCIA DO SOLO, 19., Curitiba, 1983. Programa e Resumos. Campinas: SBCS, 1983. p. 101-102.

RUSSELL, R. S. Plant root system - their function and interaction with the soil. In: SYMPOSIUM ON THE SOIL/ROOT SYSTEM IN RELATION TO BRAZILIAN AGRICULTURE, Londrina, 1980. Proceedings. Londrina: IAPAR, 1981. p. 3-19.

RUSSELL, R. S.; GOSS, M. J. Physical aspects of soil fertility; the response of roots to mechanical impedance. Netherlands Journal of Agricultural Science, v. 22, n. 3, p. 305-318, 1974.

SAAD, A. M. Uso do tensiômetro no controle da irrigação por pivô central em cultura do feijoeiro. Piracicaba, 1991. 141 p. Tese (M.S.) - Escola Superior de Agricultura "Luiz de Queiroz", Universidade de São Paulo.

SAAD, M.; DOURADO-NETO, D.; VAN LIER, Q. J. Controle de irrigação pelo método do tensiômetro na cultura do feijão sob pivô central. In: FANCELLI, A.L; DOURADO-NETO, D. (Coord.). Feijão irrigado. 3. ed., Piracicaba: ESALQ-USP, 1992. $177 \mathrm{p}$.

SAKAI, E. Desenvolvimento da cultura do milho em diferentes condições de drenagem subterrânea, no Vale do Ribeira. Piracicaba, 1996. 102 p. Tese (Doutorado) - Escola Superior de Agricultura "Luiz de Queiroz", Universidade de São Paulo.

SALGADO, A. L. de B.; BULISANI, E. A.; BRAGA, N. R.; MIRANDA, M. A. C. de. Crotalaria júncea (Crotalaria juncea L.). In: PEDRO JÚNIOR, M. P.; BULISANI, E. A.; POMMER, C. V.; PASSOS, F. A.; GODOY, I. J. de; ARANHA, C. (Ed.). Instruções Agrícolas para o Estado de São Paulo, $4^{\mathrm{a}} \mathrm{ed}$. rev. atual. Campinas, 1987. p. 81-82. (Boletim Técnico, 200). 
SALTER, P. J.; GOODE, J. E. Crop responses to water at different stages of growth. East Malling, Maidstone: Commonwealth Bureau of Horticulture and Plantation Crops, 1967. cap. 3, p.49-60.

SANDERS, J. L.; BROWN, D. A. A new fiber optic technique for measuring root growth of soybeans under field conditions. Agronomy Journal, v. 70, p. 1073-1076, 1978

SANTOS, H. P. dos. Rotação de culturas e produtividade do trigo no sul do Brasil. Piracicaba: ESALQ, 1990. 56 p.

SANTOS, H. P. dos. Efeito da rotação de culturas no rendimento, na eficiência energética e econômica do trigo, em plantio direto. Piracicaba, 1992. 131p. Tese (Doutorado) - Escola Superior de Agricultura "Luiz de Queiroz", Universidade de Sào Paulo

SANTOS, H. P. dos; REIS, E. M. Efeitos de culturas de inverno sobre o rendimento de grãos e sobre a estatura de plantas de soja. Pesquisa Agropecuária Brasileira, v. 26, n. 5, p. $729-735,1991$.

SANTOS, H. P.dos; REIS, E. M.; VIEIRA, S. A.; PEREIRA, L. R. Rotação de culturas e produtividade do trigo no Rio Grande do Sul. Passo Fundo: EMBRAPA/CNPT, 1987. 32 p. (EMBRAPA/CNPT, Documentos, 8).

SANTOS, M. M. F. B.; ANDRIGUETO, J. R.; CAMARGO, C. P.; GOEPFERT JÚNIOR, F. J. Descrição de cultivares de feijão. Brasilia: Secretaria Nacional de Produção Agropecuária, Coordenadoria de Sementes e Mudas, 1988. 50 p. 
SANTOS, H. P. dos; REIS, E. M. \& PÜTTKER, D. Culturas de inverno para plantio direto no sul do Brasil. Passo Fundo: EMBRAPA/CNPT, 1990. 24 p. (EMBRAPA/CNPT. Circular Técnica, 3).

SCHUMACHER, T. E.; SMUCKER, A. J. M. Mechanical impedance effects on oxygen uptake and porosity of drybean roots. Agronomy Journal, v. 70, p. 1073-1076, 1981.

SHARMA, R. D.; SCOLARI, D. D. G. Efficiency of green manure and crop rotation in the control of nematodes under savannath conditions. Nematologia Brasileira, v. 8, p. $191-218,1984$.

SHARMA, R. D.; PEREIRA, J.; RESCK, D. V. S. Eficiência de adubos verdes no controle de nematóides associados à soja nos cerrados. Planaltina: EMBRAPACPAC, 1982. 30 p. (EMBRAPA-CPAC. Boletim de Pesquisa, 13)

SHEA, P. F.; GABELMAN, W. H.; GERLOFF, G. C. Inheritance of efficiency in potassium utilization in snap beans (Phaseolus vulgaris L.). American Society for Horticultural Science. Proceedings, v. 91, p. 286-293, 1967.

SHEAR, G. M.; MOSCHLER, W. W. Continuous corn by the no tillage and conventional tilled methods. Agronomy Journal, v. 61, p. 524-526, 1969.

SHIBLES, R. M.; WEBER, C. R. Leaf area, solar radiation interception and dry matter accumulation by soybeans. Crop Science, v. 5, p. 575-578, 1965.

SHIERLAW, J.; ALSTON, A. M. Effect of soil compaction on root growth and uptake of phosphorus. Plant and Soil, v. 77, n. 1, p. 15-28, 1984.

SHRADER, W. D.; PESEK, J.; SCHALLER, F. W. Crop rotations. Facts and fiction. Iowa Farm Science, v. 16, p. 6-9, 1962. 
SIDIRAS, N.; ROTH, C. H. Medições de infiltração com infiltrômetros e um simulador de chuvas em latossolo roxo distrófico, Paraná, sob vários tipos de cobertura do solo e três sistemas de preparo. In: CONGRESSO BRASILEIRO DE CONSERVAÇÃO DO SOLO, 5., Porto Alegre, 1984. Programa. Porto Alegre, 1984. p. 49.

SIDIRAS, N.; VIEIRA, M. J. Compactação em latossolo roxo provocada pelas rodas do trator na semeadura: comportamento físico do solo e rendimento de três culturas. Pesquisa Agropecuária Brasileira, v. 19, p. 1285-1293, 1984.

SIDIRAS, N.; ROTH, C. H.; FARIAS, G. S. Efeito da intensidade de chuva na desagregação por impacto de gotas em três sistemas de preparo do solo. Revista Brasileira de Ciência do Solo, v. 8, n. 2, p. 251-254, 1984.

SILVA, I. F. Efeitos de sistema de manejo e tempo de cultivo sobre propriedades fisicas de um latossolo. Porto Alegre, 1980, 80 p. Dissertação (M.S.) - Faculdade de Agronomia, Universidade Federal do Rio Grande do Sul.

SILVA, E.L. Suscetibilidade do feijoeiro (Phaseolus vulgaris L.) cv. Goiano Precoce a inundações temporárias do sistema radicular em diferentes fases do seu ciclo vegetativo. Piracicaba,1982.76 p. Dissertação (Mestrado) - ESALQ/USP.

SILVA, J.T.A. da; GONZAGA, V.; SATURNINO, H.M. Efeito da incorporação de leguminosas sobre a produção do feijoeiro. In: REUNIÃO BRASILEIRA DE FERTILIDADE DO SOLO E NUTRIÇÃO DE PLANTAS, 22., 1996, Manaus. Resumos expandidos. Manaus: Editora da Universidade do Amazonas, 1996. 1 v. p.30-31.

SILVEIRA, P. M. da; SILVA, J. G. da. Efeito do preparo do solo e da rotação de cultura sobre o rendimento do feijoeiro irrigado. In: REUNIÃO NACIONAL DE PESQUISA DE FEIJÃO, 5., 1996, Goiânia. Anais. Goiânia: EMBRAPA-CNPAF-APA, 1996. v.1. p.462-464 (EMBRAPA-CNPAF. Documentos, 69). 
SILVEIRA, P. M. da; STEINMETZ, S; GUIMARÃES, C. M.; AIDAR, H.; CARVALHO, J. R. P. de. Lâminas de água e turnos de rega na cultura do feijoeiro de inverno. Pesquisa Agropecuária Brasileira, v. 19, n. 2, p. 219-223, 1984.

SIVAKUMAR, M. V. K.; SHAW, R. H. Relative evaluation of water stress indicators for soybeans. Agronomy Journal, v. 70, p. 619-623, 1978.

SLONEKER, L. L.; MODENHAUER, W. C. Measuring the ammounts of crop residue remaining after tillage. Journal of Soil and Water Conservation, v.32, p. 231-236, 1977.

SMITH, F. L.; PRYOR, R. H. Effects of maximum temperature and age of flowering and seed production in three bean varieties. Hilgardia, v. 33, n. 12, p. 669-688, 1962.

SÖNDAHL, M. R.; MAGALHÃES, A. C.; MONTOJOS, J. C. Efeito da temperatura no crescimento, florescimento e produção em duas variedades de feijão (Phaseolus vulgaris L.). In: SIMPÓSIO BRASLLIRO DE FEIJÃO, 1. Campinas, 1971. (Mimeografado)

STOBBE, E. H.; ORMROD, D. P.; WOOLEY, C. J. Blossoming and fruit set patterns in Phaseolus vulgaris L. as influenced by temperature. Canadian Journal of Botany, v. 44, p. 813-819, 1966.

STOLF, R. Teoria e teste experimental de fórmulas de transformação dos dados de penetrômetro de impacto em resistência do solo. Revista Brasileira de Ciência do Solo, v. 15 , p. 229-235, 1991.

STOLF, R.; FERNANDES, J.; FURLANI NETO, V. Penetrômetro de impacto-modelo IAA/Planalsucar-STOLF (Recomendações para o seu uso). STAB, v.1, n.3, p.18-23, 1983. 
STONE, L. F.; MOREIRA, J. A. A. Irrigação do feijoeiro. Goiânia: EMBRAPACNPAF, 1986. 31 p. (EMBRAPA-CNPAF. Circular Técnica,20).

STONE, L. F.; PEREIRA, A. L. Sucessão arroz-feijão irrigados por aspersão: efeitos de espaçamento entre linhas, adubação e cultivar no crescimento, desenvolvimento radicular e consumo d'água do feijoeiro. Pesquisa Agropecuária Brasileira, v. 29, n. 6, p. 939-954, 1994.

STONE, L. F.; SARTORATO, A. O cultivo do feijão: recomendações técnicas. Brasília: EMBRAPA-SPI, 1994. 83 p. (EMBRAPA- CNPAF. Documentos, 48)

STONE, L. R.; TEARE, I. D.; NMICKELL, C. D.; MAYAKI, W. C. Soybean root development and soil water depletion. Agronomy Journal, v. 68, p. 677-680, 1976.

STONE, L. F.; PORTES, T. de A.; MOREIRA, J. A. A. Efeito da tensão de água do solo sobre a produtividade e crescimento do feijoeiro. II. Crescimento. Pesquisa Agropecuária Brasileira, v. 23, n. 5, p. 503-510, 1988.

STONE, L. F.; PORTES, T. de A.; MOREIRA, J. A. A. Efeitos da tensão de água do solo sobre a produtividade e o crescimento do feijoeiro. II. Crescimento. In: SILVA, C. C. da; SILVEIRA, P. M. da; SILVA, J. G. da.; AIDAR, H. (Coord.). REUNIÃO SOBRE FEIJÃO IRRIGADO (GO, DF, MG, ES, SP, RJ), 1., Goiânia, 1990. Anais. Goiânia: EMBRAPA-CNPAF, 1990. p.112. (EMBRAPA-CNPAF. Documentos, 27).

SUTHERLAND, W. N.; SHRADER, W. D.; PESEK, J. T. Efficiency of legume residue nitrogen and inorganic nitrogen in corn production. Agronomy Journal, v. 53, n. 5, p. 339-342, 1961.

TACKETT, J. L.; PEARSON, R. W. Oxygen requirements of cotton seedling roots for penetration of compacted soil cores. Soil Science Society American Proceedings, v. 28, p. $600-605,1964$. 
TANAKA, A.; FUJITA, K. Growth, photosynthesis and yield component in relation to grain yield of the field bean. Journal of Faculty of Agricultural Hokkaido University, v. 59, n.2, p. 145-238, 1979.

TAYLOR, H. M. Root behaviour as affected by soil structure ans strenght. In: CARSON, E.W. (Ed). The plant root and its environment. Charlottesville: University Press of Virginia, v. 11, p. 271-291, 1974.

TAYLOR, H. M.; ARKIN, G. F. Root zone modification: fundamentals and alternatives. In: ARKIN, G.F.; TAYLOR, H.M. (Eds.). Modifying the root environment to reduce crop stress. St. Joseph, MI:ASAE, 1981.

TAYLOR, H. M; RATLIFF, L. F. Root elongation rates of cotton and peanuts as function of soil strenght and soil water content. Soil Science, v. 108, p. 113-119, 1969.

TAYLOR, H. M.; ROBERTSON, G. M.; PARKER, J. J. Soil strenght-root penetration for medium-to-coarse-textured soil materials. Soil Science, v. 102, p. 18-22, 1966.

TENNANT, D. A test of modified line intersect method of estimating root lenght. Journal of Ecology, v. 63, n. 3, p. 995-1001, 1975.

THORNTHWAITE, C. W. Temperature relations to time maturity of vegetable crops. The John Hopkins University, Laboratory of Climatology, Seabrok, New Jersey, 1952.

THUNG, M. D. T.; CUNHA, L. F. da; FERREIRA, R. M. Efeito do nível de fósforo e do nível do lençol freático constante no crescimento e no rendimento do feijoeiro. In: REUNIÃO SOBRE FEIJÃO IRRIGADO (GO,DF,MG,ES,SP,RJ), 1., Goiânia, 1988. Anais. Goiânia: EMBRAPA-CNPAF, 1990. p.130-139 (Documentos, 27).

TOMAZINI, R. G. A. Diversificação de culturas de inverno na região tritícola do sul do Brasil. $2^{\text {a }}$ ed. Passo Fundo, EMBRAPA/ CNPT, 1987. 54 p. (EMBRAPA/CNPT. Documentos, 5) 
TRANI, P. E.: HIROCE, R. \& BATAGLIA, O. C. Análise foliar; amostragem e interpretação. Campinas: Fundação Cargill, 1983. 18 p.

TU, J.C.; TAN, C.S. Effect of soil compaction on growth, yield and root rots of white beans in clay loam and sandy loam soil. Soil Biol. Biochemistry, v.23. n. 3, p. 233$238,1991$.

TURK, K. J.; HALL, A. E. Drought adaptation of cowpea. III. Influence of drought on plant growth and relations with seed yield. Agronomy Journal, v.72, p. 428-433, 1980

VEIHMEYER, F. J.; HENDRICKSON, A. H. Soil density and root penetration. Soil Science, v. 65, n. 4, p. 487-493, 1948.

VIEGAS, G. P.; MACHADO, D. A. Rotação de culturas: uma prática lucrativa. São Paulo: Sementes Cargill Ltda, 1990. 28 p.

VIEIRA, C. O feijoeiro comum: cultura, doenças e melhoramento. Viçosa: Imprensa Universitária, $1967.220 \mathrm{p}$.

VIEIRA, C. Cultura do Feijão. Viçosa: Imprensa Universitária,1978.146 p.

VIEIRA, C. Doenças e pragas do feijoeiro. Viçosa, UFV, 1988. $231 \mathrm{p}$.

VIEIRA, M. J.; MUZILLI, O. Características fisicas de um latossolo vermelho-escuro sob diferentes sistemas de manejo. Pesquisa Agropecuária Brasileira, v. 19, p. 873$882,1984$.

VIEIRA, R. F.; VIEIRA, C.; RAMOS, J. A. de O. Produção de sementes de feijão. Viçosa: EPAMIG,1993. 131 p. 
VILHORDO, B. W:; MIKUSINSKI, O. M. F.; BURIN, M. E; GANDOLFI, V. H. Morfologia. In: ARAÚJO, R. S.; RAVA, C. A.; STONE, L. F.; ZIMMERMANN, M. J. de O. Cultura do Feijoeiro Comum no Brasil. Piracicaba: POTAFOS, 1996. p.71-99.

VOLKMAR, K. M. A comparison of minirhizotron techniques for estimating root lenght density in soils of different bulk densities. Plant and Soil, v. 157, p.239-245, 1993.

VOORHEES, W. B.; JOHNSON, J. F.; RANDALL, G. W.; NELSON, W. W. Corn growth and yield as affected by surface and subsoil compaction. Agronomy Journal, v. 81, p. 294-303, 1989.

WALLACE, D. H.; MUNGER, H. M. Studies of physiological basis for yield differences. I.Growth analysis of six dry beans varieties. Crop Science, v.5, p.343$348,1965$.

WEAVER, J. E.; JEAN, F. C.; CRIST, J. W. Development and activities of roots of crop plants. Carnegie Inst. Wash. Publ., n. 316. 1922.

WHITE, J. W. Conceptos basicos de la fisiológia del frijol: guía de estudio para ser usada como complemento de la unidad audiotutorial sobre el mismo tema. Colombia: CIAT, 1988. 56 p. (Serie: 04 5B-07.01)

WHITE, J. W.; IZQUIERDO, J. Physiology of yield potential and stress tolerance. In: SCHOONHOVEN, A. van.; VOYSEST, O.(Ed.). Common Beans: Research for Crop Improvement .Cali: CAB International, CIAT, 1991. p. 287-382.

WHITE, J. W.; CASTILLO, J. A.; EHLERINGER, J. Associations between productivity, root growth and carbon isotope discrimination in Phaseolus vulgaris under water deficit. Australian Journal of Plant Physiology, v.17, n. 1, p. 189-198, 1990. 
WILCOX, G.E.; FAGERIA, N.K. Deficiências nutricionais do feijão, sua identificação e correção. Goiânia: CNPAF/EMBRAPA, 1976, 22 p.(Boletim técnico, $5)$.

WISCHMEIER, W. H. Cropping-management factor evaluations for a universal soil-loss equation. Soil Science Society of America Proceedings, v. 24, p. 322-326, 1960.

WIT, C. T. de. Transpiration and crop yields. Versl. Landbouwk. Onderz., v. 64, n. 6, p. $1-88,1958$.

WÜNSCH, W. A.; DENARDIN, J. E. Perdas de solo e escorrimento de água sob chuva natural em latossolo vermelho escuro nas culturas de trigo e soja. In: ENCONTRO NACIONAL DE PESQUISA SOBRE CONSERVAÇÃO DO SOLO, 2., Passo Fundo, 1978. Anais. Passo Fundo, EMBRAPA/CNPT, 1978 p.289-96.

WUTKE, E. B. Adubação verde: manejo da fitomassa e espécies utilizadas no Estado de São Paulo. In: WUTKE, E. B.; BULISANI, E. A.; MASCARENHAS, H. A. A. (Coord.). Curso sobre adubação verde no Instituto Agronômico,1., Campinas, 1993. p. 17-29. (Documentos IAC, 35)

YAPA, L. G. G.; FRITTON, D. D.; WILLATT, S. T. Effect of soil strenght on root growth under different water conditions. Plant and Soil, v. 109, p.9-16, 1988.

YOKOYAMA, L. P.; BANNO, K.; KLUTHCOUSKI, J. Aspectos socioeconômicos da cultura. In: ARAÚJO, R. S.; RAVA, C. A.; STONE, L. F.; ZIMMERMANN, M. J. de O. (Coord.). Cultura do feijoeiro comum no Brasil. Piracicaba: POTAFOS, 1996. Seção I. p.1-21.

YOSHIDA, S. Physiological aspects of grain yield. Annual Review Plant Physiology, v. 23, p. 437-464, 1972. 
YOUNGDAHL, L. J.; PACHECO, R.; STREET, J. J.; VLEK, P. L. G. The kinetics of ammonium and nitrate uptake by young rice plants. Plant and Soil, v.69, p.225-232, 1982.

ZAUMEYER, W. J.; THOMAS, H. R. A monographyc study of bean diseases and methods for their control (rev.ed.). Washington, USA, USDA, 1957. 255 p. (Technical Bulletin, 868).

ZHANG, J.; ELLIOTT, R. L.; KETRING, D. L. Root distribution models applied to peanuts. American Society of Agricultural Engineers, v.36, n.3, p.727-734, 1993.

ZULLO JÚNIOR, J; ARRUDA, F. B. Programa computacional para ajuste de equações em dados experimentais. Campinas: Instituto Agronômico, 1987. 31 p. (Boletim técnico, 113). 